UNIVERSIDADE DE SÃO PAULO

FACULDADE DE ECONOMIA, ADMINISTRAÇÃO E CONTABILIDADE DE RIBEIRÃO PRETO

DEPARTAMENTO DE ADMINISTRAÇÃO

\title{
O PROCESSO DE INTERNACIONALIZAÇÃO DO DESENVOLVIMENTO DE PRODUTOS EM EMPRESAS MULTINACIONAIS BRASILEIRAS
}

PAULO GUILHERME D'ALBUQUERQUE SILVEIRA MOURA

Orientadora: $\operatorname{Prof}^{\mathrm{a}} \operatorname{Dr}^{\mathrm{a}}$ Simone Vasconcelos Ribeiro Galina

\author{
Ribeirão Preto
}

2007 
Reitora da Universidade de São Paulo

Prof ${ }^{a}$. Dra . Suely Vilela

Diretor da Faculdade de Economia, Administração e Contabilidade de Ribeirão Preto Prof. Dr. Rudinei Toneto Júnior

Chefe do Departamento de Administração

Prof. Dr. Márcio Mattos Borges de Oliveira 
PAULO GUILHERME D'ALBUQUERQUE SILVEIRA MOURA

\section{O PROCESSO DE INTERNACIONALIZAÇÃO DO DESENVOLVIMENTO DE PRODUTOS EM EMPRESAS MULTINACIONAIS BRASILEIRAS}

Dissertação a ser apresentada à Faculdade de Economia, Administração e Contabilidade de Ribeirão Preto, para obtenção do título de mestre em Administração no programa de Pós-Graduação em Administração das Organizações.

Orientadora: $\operatorname{Prof}^{\mathrm{a}}$. Dr ${ }^{\mathrm{a}}$. Simone Vasconcelos Ribeiro Galina

Ribeirão Preto 
AUTORIZO A REPRODUÇÃO TOTAL OU PARCIAL DESTE TRABALHO, POR QUALQUER MEIO CONVENCIONAL OU ELETRÔNICO, PARA FINS DE ESTUDO E PESQUISA, DESDE QUE CITADA A FONTE.

\section{FICHA CATALOGRÁFICA}

Moura, Paulo Guilherme D’Albuquerque Silveira

O processo de internacionalização do desenvolvimento de produtos em empresas multinacionais brasileiras. Ribeirão Preto, 2007.

132 p. : il. ; $30 \mathrm{~cm}$

Tese de Mestrado, apresentada à Faculdade de Economia, Administração e Contabilidade de Ribeirão Preto/USP. Departamento de Administração.

Orientador: Galina, Simone Vasconcelos Ribeiro.

1. Internacionalização de Empresas. 2. Internacionalização de P\&D. 3. Desenvolvimento de produtos. 4. Empresas multinacionais brasileiras. 
MOURA, Paulo Guilherme D’Albuquerque Silveira. O processo de internacionalização do desenvolvimento de produtos em empresas multinacionais brasileiras. $132 \mathrm{f}$. Dissertação (mestrado). Faculdade de Economia, Administração e Contabilidade de Ribeirão Preto, Universidade de São Paulo, Ribeirão Preto, 2007.

\section{Errata}

\begin{tabular}{|c|c|c|c|}
\hline Folha & Linha & Onde se lê & Leia-se \\
\hline 37 & 22 & como o da a visão & como o da visão \\
\hline 43 & 10 & de aeronaves regionais), & de aeronaves), \\
\hline 44 & 7 & P\&d & P\&D \\
\hline 59 & 7 & quandp & quando \\
\hline 65 & 6 & informções & informações \\
\hline 70 & 20 & nenhum & nenhuma \\
\hline 72 & 22 & trabalho assessoria & trabalho de assessoria \\
\hline 83 & 3 & tradicionais, e especiais & tradicionais e especiais \\
\hline 92 & 9 & paises & países \\
\hline 94 & 6 & tempo, a abriu & tempo, abriu \\
\hline 95 & 5 & sendo as & sendo que as \\
\hline 96 & 24 & realização pesquisa & realização de pesquisa \\
\hline 97 & 6 & $\begin{array}{l}\text { O único caso diferente foi o da SMAR } \\
\text { que teve um início de } \\
\text { internacionalização caracterizado como } \\
\text { não planejado, segundo seus } \\
\text { representantes. Contudo, ao perceber } \\
\text { que a região era promissora, a empresa } \\
\text { montou um plano de } \\
\text { internacionalização e, em pouco tempo, } \\
\text { instalou um escritório e uma fábrica. A } \\
\text { vantagem apresentada pela rapidez na } \\
\text { aquisição de componentes para a } \\
\text { montagem dos produtos foi o fator que } \\
\text { levou a empresa a se internacionalizar. }\end{array}$ & $\begin{array}{l}\text { O caso diferente foi o da } \\
\text { SMAR, que teve como } \\
\text { vantagem apresentada para sua } \\
\text { internacionalização a rapidez } \\
\text { na aquisição de componentes } \\
\text { para a montagem dos produtos. }\end{array}$ \\
\hline $\begin{array}{c}105 \\
\text { terceira } \\
\text { coluna }\end{array}$ & $\begin{array}{c}3, \\
7,11 \\
15,19, \\
23 .\end{array}$ & seuas & suas \\
\hline 108 & 9 & da estratégia da tecnológica & da estratégia tecnológica \\
\hline 111 & 6 & um maneira & uma maneira \\
\hline
\end{tabular}




\section{FOLHA DE APROVAÇÃO}

Paulo Guilherme D’Albuquerque Silveira Moura

O processo de internacionalização do desenvolvimento de produtos em empresas multinacionais brasileiras

Dissertação a ser apresentada à Faculdade de Economia, Administração e Contabilidade de Ribeirão Preto, para obtenção do título de mestre em Administração no programa de Pós-Graduação em Administração das Organizações.

Aprovada em:

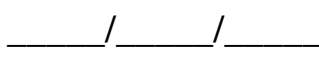

Banca Examinadora

Prof.(a) Dr.(a):

Instituição:

Assinatura:

Prof.(a) Dr.(a):

Instituição:

Assinatura:

Prof.(a) Dr.(a):

Instituição: Assinatura: 
Dedico este trabalho à minha família pelo apoio e carinho, à minha orientadora, pela oportunidade que me oferecu, e aos futuros leitores, pelo interesse. 


\section{AGRADECIMENTOS}

Primeiramente, agradeço à minha orientadora, $\operatorname{Prof}^{\mathrm{a}} \operatorname{Dr}^{\mathrm{a}}$ Simone Galina, pela oportunidade que me ofereceu de fazer este mestrado, e pelos puxões de orelha que me direcionaram para a conclusão de um trabalho de qualidade.

À banca de qualificação composta pelas professoras $\operatorname{Dr}^{\mathrm{a}}$ Geciane Porto e $\operatorname{Dr}^{\mathrm{a}}$ Flávia Consoni, pela leitura meticulosa do trabalho e pelas sugestões que o enriqueceram.

Aos professores e funcionários da Faculdade de Economia, Administração e Contabilidade de Ribeirão Preto, que forneceram o suporte docente, administrativo, informático, e estrutural imprescindível à realização da pesquisa.

Às empresas e aos entrevistados, que cederam seus valiosos tempo e informações.

À FAPESP, pelo apoio financeiro e institucional.

Ao GINEBRA e ao GETEC, pelas discussões e apoio institucional.

Aos funcionários da biblioteca, principalmente aos reponsáveis pelos serviços do COMUT e de revisão e apoio constante.

À minha família, pelo incentivo, compreensão e carinho.

À minha mãe, pela revisão ortográfica e à minha irmã pela versão do resumo.

Aos amigos que conhecí em Ribeirão Preto: Cláudia, Thaís, Mitie, Miriam, Vanessa, Priscila, Luciano, Julio, Adriano, Flávia, Carol, Orliene, Roberta, Dayele, Ivete, Akira, Titton, Charles, Thiago, Julio, Dennys, Dalton, Rogério, Mazinha, Carlos, Ivan, Maurício, Juliana, Pedro, Magnus, Andrei, Tatiana, Rafael, Mara, Marli, Lísia, Flávinho, Flávio Glete, Marcelo, Vitor, Marco, Ângela, Akira, Fran, Thiago, Juliana, Roger e Scatena pela amizade e convivência. 
If you have an apple and I have an apple and we exchange apples then you and I will still each have one apple. But if you have an idea and I have an idea and we exchange these ideas, then each of us will have two ideas.

George Bernard Shaw A mente, como um pára-quedas, só funciona quando aberta.

Anônimo Não entre em pânico.

Douglas Adams 


\section{RESUMO}

MOURA, Paulo Guilherme D’Albuquerque Silveira. O processo de internacionalização do desenvolvimento de produtos em empresas multinacionais brasileiras. $132 \mathrm{f}$. Dissertação (mestrado). Faculdade de Economia, Administração e Contabilidade de Ribeirão Preto, Universidade de São Paulo, Ribeirão Preto, 2007.

Atualmente, o conhecimento, a técnica e a inovação tornaram-se fatores críticos para o desenvolvimento de vantagens competitivas. $\mathrm{O}$ fator tecnológico, com suas rápidas taxas de propagação e obsolescência, apresenta um desafio ímpar para a gestão de uma empresa. Nesse contexto, as empresas utilizam sua função de pesquisa e desenvolvimento (P\&D) como forma de tomar conhecimento do ambiente tecnológico global, de suas mudanças e tendências, das inovações em desenvolvimento de produtos e dos impactos destas em relação ao seu negócio. Ao mesmo tempo, com a internacionalização, as empresas ficaram aptas a desenvolver, produzir e comercializar seus produtos em diferentes localidades, o que resultou em um aumento da complexidade gerencial. Assim, o desenvolvimento global de produtos passou a ser um fator-chave para o sucesso da estratégia organizacional, tornando-se imperativo coordenar os avanços tecnológicos globais com as necessidades dos mercados. Todas essas mudanças obrigaram as empresas multinacionais, inclusive as brasileiras, a ampliarem suas fronteiras tecnológicas de ação, pesquisando e desenvolvendo globalmente produtos e processos, tanto para um mercado mundial quanto para cada mercado local. Focando no processo de desenvolvimento de produtos, este trabalho estuda casos desse tipo de internacionalização em seis empresas multinacionais brasileiras. Os resultados mostraram que, em apenas dois caso, essa internacionalização do desenvolvimento de produto ocorreu por decisão da empresa. Em três outros, houve a internacionalização derivada de competências pré-existentes nas empresas, e, no último não houve internacionalização do desenvolvimento.

Palavras-chaves: Internacionalização de empresas, Internacionalização de P\&D e Desenvolvimento de produtos. 


\begin{abstract}
MOURA, Paulo Guilherme D'Albuquerque Silveira. The process of internationalization of product development in Brazilian multinationals. $132 \mathrm{f}$. Dissertation (Master's degree). Faculty of Economics, Business Administration and Accounting - Ribeirão Preto, Universidade de São Paulo, Ribeirão Preto, 2007.
\end{abstract}

Nowadays, the knowledge, the technique and the innovation have become critical factors for the development of competitive advantages. The technological factor, with its rapid rate of propagation and obsolescence, represents a challenge for the management of firms. In this context, firms must be aware of the global technological environment, its changes and tendencies, innovations regarding the development of products and also the impacts of those in the firms' business. At the same time, with the internationalization firms become capable to develop, manufacture and commercialize in different locations increasing the complexity of management. So, the global development of products becomes a key-factor for the success of the organizational strategy, because it has become crucial to coordinate the global technological advancements to the markets' needs. All these changes lead multinationals, including the Brazilian ones, to extend its technological borders to global research, and to develop products and processes for local and global markets. Researching the process of product development, this dissertation presents a multiple case study of internationalization of the product development on Brazilian multinationals, aiming to answer the following question: how did the process of internationalization of firms motivate the internationalization of the product development? The results shown that for one multinational occurred the internationalization, for four others, this internationalization was "incidental" and for the last one there were no internationalization whatsoever.

Keywords: Internationalization of firms, R\&D internationalization and Product development. 


\section{SUMÁRIO}

$\begin{array}{ll}\text { INTRODUÇÃO } & 13\end{array}$

$\begin{array}{ll}1.1 \text { OBJETIVOS } & 18\end{array}$

II - REFERENCIAL TEÓRICO

2.1 A IMPORTÂNCIA DA INTERNACIONALIZAÇÃO 19

2.2 A FUNÇÃO DE PESQUISA E DESENVOLVIMENTO (P\&D) 30

2.3 INTERNACIONALIZAÇÃO DE P\&D 36

2.4 DESENVOLVIMENTO GLOBAL DE PRODUTOS $\quad 51$

2.5 MULTINACIONAIS DE PAÍSES EMERGENTES

2.6 INTERNACIONALIZAÇÃO E P\&D EM EMPRESAS BRASILEIRAS 54

2.7 OS OBJETIVOS E AS PROPOSIÇÕES DO TRABALHO

III - ASPECTOS METODOLÓGICOS $\quad 58$

$\begin{array}{ll}3.1 \text { TIPO DE PESQUISA } & 58\end{array}$

3.2 COLETA DE DADOS: MÉTODO E INSTRUMENTO $\quad 60$

3.3 PROTOCOLO DO ESTUDO DE CASO 62

$\begin{array}{ll}\text { 3.4 AS EMPRESAS ESTUDADAS } & 67\end{array}$

IV - ANÁLISE E DISCUSSÃO DOS RESULTADOS

4.1 APRESENTAÇÃO DOS DADOS

4.2 CONFRONTO DOS CASOS COM O REFERENCIAL 93

V - CONSIDERAÇÕES FINAIS $\quad 108$

$\begin{array}{ll}5.1 \text { CONCLUSÕES } & 108\end{array}$

5.2 LIMITAÇÕES E PROPOSTAS DE PESQUISAS POSTERIORES 114

REFERÊNCIAS

$\begin{array}{ll}\text { APÊNDICES } & 124\end{array}$

A - AS EMPRESAS SELECIONADAS 124 


\section{LISTA DE QUADROS}

Quadro 1.1 - Empresas com plantas produtivas no exterior .......................................... 16

Quadro 1.2 - Localização das unidades das empresas selecionadas................................... 17

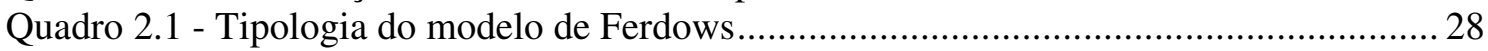

Quadro 2.2 - Competência do sítio versus estratégia da planta........................................... 29

Quadro 2.3 - Modelo de Gassmann e Von Zedtwitz para a internacionalização de P\&D....... 48

Quadro 2.4 - As funções das unidades no exterior ....................................................... 50

Quadro 2.5 - A função da unidade de tecnologia regional............................................... 51

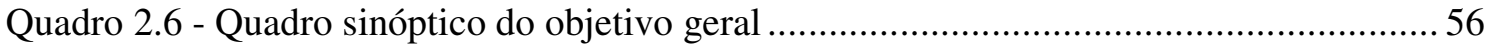

Quadro 2.7 - Quadro sinóptico dos objetivos específicos.................................................57

Quadro 3.1 - As proposições e as questões pertinentes do roteiro de entrevistas ................... 66

Quadro 4.1 - Esquema de apresentação e discussão dos dados......................................... 71

Quadro 4.2 - O modelo de Ferdows (1997) aplicado nas plantas estudadas........................ 102

Quadro 4.3 - Quadro sinóptico dos modelos de internacionalização de P\&D e as empresas

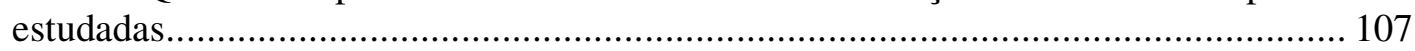

Quadro 5.1 - Quadro de respostas para o problema de pesquisa..................................... 109

Quadro A1 - Distribuição geográfica da Gerdau.......................................................... 127

Quadro A2 - Centros operacionais da Tigre no exterior ............................................... 131 


\section{INTRODUÇÃO}

Atualmente, o conhecimento, a técnica e a inovação tornaram-se fatores críticos para o desenvolvimento de vantagens competitivas, e a habilidade das organizações na gestão desses fatores, de forma a aprimorar sua competitividade, é o principal desafio deste começo de século (SBRAGIA; STAL, 2002). As transformações tecnológicas dos últimos anos modificaram os produtos, processos e, como esperado, também as organizações. Neste panorama de difusão acelerada do progresso tecnológico, são observados um aumento na taxa de inovação e uma redução no período de tempo necessário entre a concepção e o desenvolvimento do projeto, e sua inserção no mercado (LAMBIN, 2000). Com isso, a inovação e a tecnologia tornaram-se fontes-chave da força competitiva (REDDY, 1997).

Ao mesmo tempo, os avanços tecnológicos e financeiros ocorridos nas décadas de 80 e 90 fortaleceram o processo de globalização (VIEIRA; ZILBOVICIUS, 2005), integrando as economias nacionais por meio de fluxos de comércio, de capital, de tecnologia e da produção internacional de bens e serviços (DIAS, 1994).

Com relação aos fluxos de tecnologia e à produção internacional, Chiesa (2000) aponta como aspecto importante do processo de globalização das atividades empresariais, a realização de atividades tecnológicas no exterior. As explicações para isso são que, além da manufatura e do marketing no estrangeiro necessitarem de suporte técnico, a dispersão geográfica das instalações técnicas facilita a penetração em mercados estrangeiros.

Considerando a sinergia existente entre a internacionalização e a inovação tecnológica, e agregando a necessidade de envolvimento no desenvolvimento de produtos, pode-se perguntar qual seria o papel representado pela função de pesquisa e desenvolvimento - P\&D - na internacionalização das empresas multinacionais brasileiras - MNB. 
Convencionalmente essa função é vista sob uma única ótica: a da geração de novos conhecimentos. No entanto, em uma outra visão, a função propiciaria o aumento da capacidade da firma de assimilar e explorar o conhecimento já existente (COHEN; LEVINTHAL, 1989). Com isso, ao internacionalizar sua função de P\&D, a empresa pode vir a se tornar uma plataforma (ou aprimorar a já existente) para a criação, exploração e aquisição de tecnologias e competências inovadoras, desenvolvendo suas vantagens competitivas sustentáveis e contribuindo para o amadurecimento do sistema nacional de inovação. Assim, as firmas poderiam dispersar geograficamente suas unidades de P\&D como forma de acessar o conhecimento que é desenvolvido e acumulado nos diferentes locais onde atua.

Porém, na dinâmica organizacional atual, somente o acesso à tecnologia não é mais suficiente para uma empresa adaptar-se às novas condições técnicas e de evolução do conhecimento. Nessa época de mudanças rápidas, somente aqueles que estão envolvidos na criação do conhecimento dispõem de possibilidades reais de absorver e fazer uso pleno deste acesso (CASSIOLATO; LASTRES, 2005). Neste quadro, a internacionalização surge como uma possível estratégia a ser adotada para adquirir novos conhecimentos e desenvolver inovações.

Além disso, as empresas não estão restritas somente a uma dicotomia de escolhas ficar no país de origem ou ir para o exterior - para aproveitarem as fontes de conhecimento globalizadas. Existem ainda outras opções disponíveis para acessar recursos específicos advindos da internacionalização (NARULA; DUYSTERS, 2004). Por exemplo, as multinacionais - MNC - podem dispersar seu P\&D por meio da utilização de alianças tecnológicas com outras empresas, com universidades e com institutos de pesquisa (VON ZEDWITZ, 2005).

Nessa expansão de $\mathrm{P} \& \mathrm{D}$, as MNC procuram obter vantagens competitivas por meio do sensoriamento das necessidades de um país, respondendo com capacidades alocadas em um 
outro, e dispersando as inovações resultantes nos mercados ao redor do mundo (BARTLETT; GHOSHAL, 1992). Como resultado, essas empresas transcendem as fronteiras nacionais, não somente em produção e marketing, mas também em P\&D (REDDY, 1997), tornando o gerenciamento dessas atividades mais complexo, uma vez que envolvem a coordenação e o controle de unidades dispersas geograficamente (CHIESA, 2000).

Nos últimos anos, a escala de internacionalização aumentou tanto, que seu alcance geográfico já abrange, inclusive, os países em desenvolvimento. Dados obtidos das subsidiárias de MNC da Tríade (Estados Unidos, Japão e União Européia) confirmam este crescimento (VON ZEDWITZ, 2005). No âmbito global, entre 1993 e 2002, o investimento em P\&D realizado por subsidiárias saltou de US\$ 30 bilhões para US\$ 67 bilhões. Já, os investimentos dessa mesma área alocados para subsidiárias de países em desenvolvimento aumentaram de 2\% para 18\% entre 1996 e 2002 (VON ZEDWITZ, 2005).

Vale ressaltar, que dentre os estudos publicados sobre a internacionalização de empresas, os que pesquisam o papel das subsidiárias brasileiras de MNC estrangeiras são geralmente foco dos esforços da academia. Por outro lado, estudos no sentido inverso, o de subsidiárias internacionais de MNB e sua atuação produtiva no mercado global, só agora estão sendo estruturados. Talvez isso se deva ao fato de que a criação de subsidiárias de produção, fora das fronteiras nacionais, seja um fenômeno ainda muito recente (HEMAIS; HILAL, 2003).

Este trabalho faz parte de um projeto temático da FAPESP que visa esclarecer os múltiplos aspectos da gestão da internacionalização de empresas brasileiras. A contribuição desta dissertação foi a realização de um estudo de casos múltiplos, abordando a relação das empresas brasileiras com unidades produtivas no exterior, e a internacionalização da função $\mathrm{P} \& \mathrm{D}$, focalizando o desenvolvimento global de produto. 
O Brasil já possui um grande número de empresas com atividades no exterior, porém ainda são poucas as que realizam investimentos diretos produtivos no exterior (IGLESIAS; MOTTA VEIGA, 2002). O quadro 1.1, compilado a partir dos estudos de Altmann (2005); pesquisas no jornal (NETZ, 2006) e visita aos sites, apresenta uma lista dessas empresas:

\begin{tabular}{|c|c|}
\hline \multicolumn{2}{|c|}{ Empresas brasileiras com unidades produtivas no exterior } \\
\hline Alpargatas & Embraco \\
\hline Artecola & Embraer \\
\hline Bertin & Forjas Taurus \\
\hline Busscar & Friboi \\
\hline Camargo Corrêa Cimentos & Gerdau \\
\hline Cinex & Klabin \\
\hline Citrosuco & Marcopolo \\
\hline Coimex & Petrobrás \\
\hline Construções e Comércio Camargo Correia & Sabó \\
\hline Construtora Norberto Odebrecht & Santista têxtil \\
\hline Coopinhal & Smar \\
\hline Coteminas & Tubos Tigre \\
\hline Crystalsev & Vale do Rio Doce \\
\hline CSN & Votorantim metais \\
\hline Cutrale & Votorantim cimentos \\
\hline Duas Rodas Industrial & WEG \\
\hline Duratex & \\
\hline
\end{tabular}

Quadro 1.1 - Empresas com plantas produtivas no exterior Fonte: Altmann (2005); Netz (2006).

Com base nesse levantamento inicial, as empresas estudadas foram selecionadas por meio de uma amostragem de conveniência, e são as seguintes: Embraco, Gerdau, Marcopolo, Smar, Tigre e WEG. O quadro 1.2, referente às seis empresas, contém o número de unidades produtivas no exterior e a localização de cada uma. 


\begin{tabular}{|c|c|c|}
\hline Nome & Número de unidades no exterior & Localização das unidades \\
\hline Embraco & 3 & Itália, China e Eslováquia \\
\hline Gerdau & $\begin{array}{c}20 \text { usinas siderúrgicas; } 18 \text { unidades de } \\
\text { transformação e 4 unidades de corte e dobra } \\
\text { de aço }\end{array}$ & $\begin{array}{c}\text { Uruguai, Canadá, Argentina, Chile, Estados } \\
\text { Unidos, Colômbia, Peru e Espanha }\end{array}$ \\
\hline Marcopolo & 5 (uma desativada) & $\begin{array}{c}\text { Portugal, Colômbia, México, África do Sul e } \\
\text { Argentina (atualmente desativada) }\end{array}$ \\
\hline Smar & 2 & EUA (Nova York e Houston) \\
\hline Tubos Tigre & 6 & Paraguai, Chile, Argentina e Bolívia \\
\hline WEG & 7 & Argentina (3), México (2), Portugal e China. \\
\hline
\end{tabular}

Quadro 1.2 - Localização das unidades das empresas selecionadas

Fonte: Embraco (2006); Gerdau (2001); Marcopolo (2006) Smar (2001); Tigre (2005) e WEG (2006).

Com base no exposto anteriormente e considerando que a tendência mundial das companhias globais, dependentes de inovação para competitividade, é a de internacionalizar também suas atividades de desenvolvimento de produtos, o problema de pesquisa é: o processo de internacionalização das MNB motivou a internacionalização de suas atividades de desenvolvimento de produtos? 


\subsection{OBJETIVOS}

Tendo como base o problema de pesquisa mencionado, delimitou-se como objetivo geral:

Analisar a internacionalização das atividades de desenvolvimento de produto nas MNB selecionadas.

E como objetivos específicos:

(a) Identificar a estratégia de P\&D adotada pela organização.

(b) Verificar como estão estruturadas suas atividades de desenvolvimento de produtos.

(c) Identificar atividades de desenvolvimento de produto realizadas em suas unidades produtivas estrangeiras.

Além desses objetivos, o trabalho contém as proposições de estudo de caso que foram consideradas para a construção do roteiro de entrevistas. Essas proposições estão contidas no próximo capítulo, à medida que se apresenta o referencial teórico. O intuito dessa estrutura é relacionar e também confrontar os objetivos do trabalho com as proposições levantadas para a pesquisa, o que é feito no final do capítulo. 


\section{II - REFERENCIAL TEÓRICO}

Este referencial teórico está dividido em sete seções e expõe os tópicos que serviram de fundamento para o estudo de casos múltiplos realizado. A primeira seção apresenta a definição de internacionalização de empresas; seguindo com as teorias consolidadas na literatura internacional, e terminando com as estruturas utilizadas pelas empresas ao se internacionalizarem.

A discussão central da segunda seção é a função de pesquisa e desenvolvimento da empresa, com apresentação da definição, da divisão e do gerenciamento desta função. Na terceira seção, o foco é a internacionalização de P\&D. Após um histórico desse tipo de internacionalização no âmbito mundial, dois momentos distintos são diferenciados: o da visão tradicional e o do novo paradigma. São abordados temas atuais como as redes de P\&D, a heterogeneidade na internacionalização de $\mathrm{P} \& \mathrm{D}$, e os estudos desse tópico em multinacionais emergentes.

A quarta seção descreve o desenvolvimento global de produtos; a quinta discorre sobre as multinacionais nos países emergentes, e a sexta fornece dados sobre a internacionalização e P\&D nas empresas brasileiras. A última apresenta a integração dos objetivos da pesquisa com as proposições do estudo de caso.

\subsection{A IMPORTÂNCIA DA INTERNACIONALIZAÇÃO}

A década de 90 foi marcada pela acelerada globalização, ou seja, por um aumento tanto na extensão e no escopo da interação econômica internacional, quanto na complexidade da divisão de trabalho (GAMMELTOFT, 2005). A convergência das preferências dos consumidores em âmbito global e a difusão internacional da tecnologia têm influenciado tanto 
a velocidade quanto o local da inovação. Dessa forma, as empresas não podem mais partir da suposição de que seu ambiente doméstico vai provê-las com a tecnologia mais avançada e ambiente inovador (REDDY, 1997). Neste cenário conturbado, os administradores tiveram de compreender a natureza das forças atuantes em suas empresas e, também, desenvolver as competências organizacionais necessárias para montar suas estratégias de forma integrada, procurando com isso obter os benefícios advindos da internacionalização (BARTLETT; GHOSHAL, 1992).

Por sua vez, as multinacionais vêm apresentando um papel cada vez mais importante para o crescimento e desenvolvimento econômico mundial (ORGANIZATION FOR ECONOMIC CO-OPERATION AND DEVELOPMENT - OECD, 2004). Alguns aspectos marcantes que demonstram essa importância seriam (ALEM; CAVALCANTI, 2005):

- no início dos anos 90 , as 420 principais empresas multinacionais eram responsáveis por mais da metade da produção mundial;

- nessa mesma época, essas empresas já eram responsáveis por cerca de $75 \%$ do comércio mundial total, dos quais mais de um terço correspondia ao comércio entre empresas;

- as MNC têm sido a principal fonte privada de financiamento à pesquisa e desenvolvimento;

- a busca da internacionalização pode ser vista de uma forma mais ampla, já que os benefícios não se restringem apenas às firmas. A internacionalização gera ganhos para o país de origem em conseqüência do aumento das exportações, geração de divisas e acesso a novas tecnologias. 


\subsubsection{Primeira proposição do estudo de caso}

Tendo em vista a importância das multinacionais para o desenvolvimento tecnológico e, também, o objetivo geral do trabalho - analisar a internacionalização das atividades de desenvolvimento de produto de empresas multinacionais brasileiras - foi levantada a primeira proposição do estudo de caso $(P 1)$ :

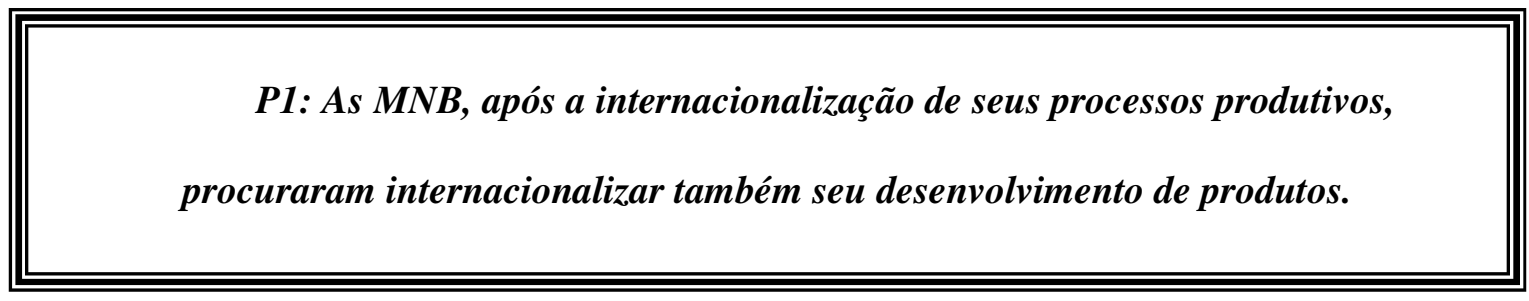

Portanto, este trabalho parte do pressuposto de que a internacionalização do desenvolvimento do produto é necessária para a empresa já inserida no ambiente globalizado.

Na próxima seção, serão discutidos o conceito de internacionalização utilizado no trabalho e as teorias existentes.

\subsubsection{A internacionalização de empresas}

De acordo com Welch e Luostarinen (1988), a internacionalização é o processo do aumento do envolvimento de uma empresa em operações entre fronteiras internacionais. Essa definição tem seu valor por ser concisa e de fácil interpretação (MORGAN; KATSIKEAS, 1997). Ao globalizar suas operações, as multinacionais se confrontam com um dilema: como organizar a autoridade central de forma a operar em um sistema vasto, procurando atingir a 
sinergia e, ao mesmo tempo, descentralizar a autoridade para que os gerentes locais possam tomar decisões para atender o mercado local? (OGBUEHI; BELLAS JUNIOR, 1992).

Estudos sobre o assunto levaram os pesquisadores a propor uma série de teorias de internacionalização que procuram explicar como e porquê uma firma se engaja em atividades no exterior, e como tal dinâmica pode ser conceituada. A internacionalização apresenta duas vertentes: na primeira, ela é analisada a partir de um critério econômico, ou seja, os motivadores econômicos que levaram as empresas a se posicionarem em diferentes países e a atuação de suas subsidiárias. Na segunda, a análise parte de conceitos comportamentais, considerando a internacionalização como um processo realizado em estágios (CARNEIRO; DIB; HEMAIS, 2005; VIEIRA; ZILBOVICIUS, 2005).

Fleury e Fleury (2006) apresentam três teorias que estão consolidadas na literatura de Negócios Internacionais (International Business): a Abordagem Comportamental da Escola de Uppsala, o Paradigma Eclético da Produção Industrial, e as Teorias Estratégicas da Internacionalização.

\subsubsection{A Abordagem Comportamental da Escola de Uppsala}

Essa abordagem considera os aspectos comportamentais e culturais como os principais determinantes do processo de internacionalização. Assim, ao contrário da abordagem eclética, não apresenta a internacionalização como o resultado de um processo racional de tomada de decisão, mas sim como sendo seqüencial, começando por atividades exportadoras e indo até a construção de unidades produtivas no exterior (MELIN, 1992). "A preocupação maior dos teóricos de Uppsala era explicar o processo de internacionalização e as forças que atuam no decorrer desse processo, e não os motivos que levam as empresas a investir no exterior" (ROCHA; ALMEIDA, 2006; p. 25). 
O modelo é baseado em teorias comportamentais com pressupostos sobre a falta de informação, a importância do risco percebido e incerteza (CAVUSGIL, 1980 apud ANDERSEN, 1993). Assim, a premissa adotada é que a falta de conhecimento sobre mercados internacionais apresenta-se como um obstáculo para o desenvolvimento das atividades no exterior (JOHANSON; VAHLE, 1977). Contudo, esse conhecimento só pode ser adquirido por meio da experiência própria com os negócios internacionais (ALTMANN, 2005).

A abordagem destaca que as empresas gerenciam o processo de internacionalização de maneira gradual, e movem-se inicialmente em direção a países que estejam culturalmente mais próximos. A partir da gestão da aprendizagem organizacional, da formação de competências e da gestão do conhecimento, vão sendo criadas as bases para que a empresa se lance em novos empreendimentos internacionais (FLEURY; FLEURY, 2006).

Por ser auto-alimentado, o processo de internacionalização tenderia a prosseguir na empresa, independentemente de considerações estratégicas. O acúmulo de experiência internacional permite à empresa assumir níveis crescentes de comprometimento de recursos, levando-a a escolher seqüencialmente modos de entrada com maior nível de propriedade e controle (ROCHA; ALMEIDA, 2006; p. 27).

Com base nesse modelo, foi desenvolvida uma escala de comprometimento em forma de entrada, apresentada a seguir, da menos comprometida (1) para a forma mais comprometida (8) (CYRINO; OLIVEIRA JUNIOR, 2002):

1. Exportação por intermédio de terceiros

2. Exportação direta

3. Licenciamento

4. Associação / Alianças estratégicas com empresas estrangeiras 
5. Franchising

6. Instalação de subsidiária / escritórios próprios voltados à comercialização

7. Instalação de subsidiária / unidade de produção

8. Centro de pesquisa

O grau de comprometimento da empresa começa, portanto, pela exportação indireta, passa pela instalação de plantas produtivas e atinge o pico com a instalação de centros de pesquisa (CYRINO; OLIVEIRA JUNIOR, 2002). Dessa forma, a internacionalização de P\&D apresentaria um alto grau de comprometimento da empresa com o país onde foi instalada.

\subsubsection{O Paradigma Eclético da Produção Industrial}

Esta segunda abordagem trata a questão da internacionalização a partir de uma perspectiva de racionalidade econômica, buscando o entendimento dos motivadores econômicos e das vantagens competitivas associadas. O paradigma está baseado na teoria econômica e apresenta os custos de transação como suas principais variáveis explicativas, junto com o pressuposto da existência de uma tomada de decisão racional por parte das firmas ao realizar investimentos diretos no exterior (MELIN, 1992). Dunning (1994) demonstra que as empresas optam por realizar esses investimentos, fundamentadas em quatro motivadores principais:

(a) "Resource seeking": a disponibilidade de recursos naturais escassos em seus países de origem, permitindo que produtos em fase mais avançada de processamento e de maior valor agregado sejam viabilizados nos países de origem;

(b) "Efficiency seeking": busca da racionalização da produção, explorando economias de especialização e localização;

(c) "Market seeking": a atratividade de mercados locais; 
(d) "Strategic asset seeking": aquisição de ativos estratégicos em termos de competências e/ou financeiros.

A aplicação dessa abordagem deve revelar a lógica econômica a ser privilegiada em um projeto de internacionalização. A diferença existente entre as estratégias das empresas multinacionais estaria na composição dessas vantagens. Assim, pode-se dizer que:

Em um grau mais avançado de internacionalização, as empresas transnacionais distribuem as várias etapas de sua cadeia produtiva por países diferentes, procurando por vantagens na produção daquela parcela específica (ALEM; CAVALCANTI, 2005; p. 46).

De acordo com o Paradigma Eclético, existem três conjuntos de vantagens que determinam se a empresa vai servir aos mercados internacionais por exportação, por transações em tecnologia, ou por produção direta no país de importados: (i) vantagens específicas da empresa (ou proprietárias); (ii) vantagens locacionais e (iii) vantagens de internalização (DIAS, 1994; ROCHA; ALMEIDA, 2006).

As vantagens proprietárias (ou específicas) são as que a empresa multinacional detém em relação às empresas domésticas. Essas vantagens estão associadas à tecnologia, marcas, capacidade organizacional, redes de distribuição e de pesquisa e desenvolvimento. As vantagens locacionais estão relacionadas tanto com o país para onde se pretende internacionalizar, quanto com o país de origem da empresa. A empresa deverá avaliar o desempenho atual e futuro das economias dos dois países e, no seu processo de decisão, serão incluídos fatores tais como os custos relativos de produção, barreiras ao comércio ou características dos mercados. As vantagens de internalização são aquelas que norteiam as ações da empresa a deixar de explorar suas vantagens específicas, cedendo direitos temporários a parceiros não associados, ou permitir que as mesmas sejam exploradas diretamente pela produção local, por meio de uma subsidiária sob controle da empresa matriz. 
2.1.2.3 As teorias estratégicas da internacionalização

A terceira abordagem trata das questões de estratégia e estrutura, ou seja, da arquitetura organizacional das empresas multinacionais. Essas teorias partem do princípio de que a estratégia adotada pelas empresas tem um papel importante no processo de internacionalização das mesmas (ROCHA; ALMEIDA, 2006). Estão baseadas nas propostas de Porter (1990) para o entendimento da maneira como as empresas devem posicionar suas estratégias de internacionalização no plano mundial. De maneira geral, a questão colocada por essa abordagem diz respeito a duas dimensões: configuração e coordenação. A configuração descreve a distribuição espacial e funcional das unidades produtivas da multinacional, enquanto a coordenação diz respeito aos sistemas e mecanismos de integração (FLEURY; FLEURY, 2006). Assim, a decisão de internacionalização da empresa está associada a movimentos competitivos dos concorrentes. Tais movimentos, por sua vez, estão associados à obtenção de vantagens e a neutralização ou superação das vantagens obtidas pela concorrência (ROCHA; ALMEIDA, 2006).

Neste trabalho foram utilizadas as três teorias. Para identificar a relação entre a estratégia global e a de $\mathrm{P} \& \mathrm{D}$, bem como as características estruturais e organizacionais da função P\&D, foi usada esta abordagem das Teorias Estratégicas de Internacionalização. Em contrapartida, para analisar os motivos que levaram a empresa a internacionalizar suas operações e, em decorrência disso, internacionalizar seu desenvolvimento de produto, foi empregada a abordagem do Paradigma Eclético. Já a Abordagem Comportamental foi utilizada para verificar se o processo de internacionalização do desenvolvimento de produto pode ser um próximo estágio de internacionalização da empresa. 


\subsubsection{Teoria de internacionalização produtiva}

Como as empresas estudadas já possuem plantas produtivas no exterior, é importante, além de analisar a sua internacionalização, focar em aspectos da sua internacionalização produtiva. Para isso, foi utilizado o modelo de Ferdows (1997) de internacionalização da produção da empresa. O modelo estuda os papéis que as plantas no exterior podem assumir e, para isso, trabalha em duas dimensões: as razões estratégicas e as competências das plantas. Para Ferdows, as razões estratégicas seriam o acesso à produção de baixo custo, o acesso a habilidades e conhecimentos, e a proximidade do mercado. A segunda dimensão analisada pelo modelo é da competência de cada planta. A partir dessas duas dimensões foram definidas seis classificações possíveis: Offshore, Outpost, Server, Source, Lead e Contributor. O quadro a seguir (2.1) contém as seis classificações e suas características. 


\begin{tabular}{|c|l|}
\hline $\begin{array}{c}\text { Tipo de } \\
\text { planta }\end{array}$ & \multicolumn{1}{c|}{ Características } \\
\hline \multirow{5}{*}{ Offshore } & $\begin{array}{l}\text { Uma fábrica "offshore" é estabelecida para ganhar acesso aos baixos } \\
\text { salários ou outros fatores que integram a produção de baixo-custo. Suas } \\
\text { responsabilidades são limitadas pela produção de itens específicos de } \\
\text { baixo custo, que depois são exportados tanto para continuar a serem } \\
\text { trabalhados em outra planta, quanto para serem vendidos. De tal fábrica } \\
\text { não se espera inovações; seus gerentes seguem as instruções, métodos e } \\
\text { planos passados a eles. Ao mesmo tempo, essas plantas dependem de } \\
\text { outras para prover a expertise em novos processos, produtos e tecnologias. }\end{array}$ \\
\hline Source & $\begin{array}{l}\text { Uma fábrica "source" também é estabelecida para ganhar acesso aos } \\
\text { baixos custos de produção; contudo, diferentemente da "offshore", ela tem } \\
\text { recursos e a expertise para desenvolver e produzir uma parte ou um } \\
\text { produto para os mercados globais da empresa. }\end{array}$ \\
\hline Server & $\begin{array}{l}\text { Uma fábrica "server" é uma instalação de produção que supre mercados } \\
\text { específicos de âmbito regional ou nacional. Seu papel estratégico é a } \\
\text { proximidade com o mercado. }\end{array}$ \\
\hline Outpost & $\begin{array}{l}\text { Uma "contributor" também apresenta como papel estratégico a } \\
\text { proximidade de mercado. Porém, além de servir a um mercado local, ela } \\
\text { assume responsabilidade para customização de produtos, aprimoramento } \\
\text { de processos, modificação e desenvolvimento de produtos. }\end{array}$ \\
\hline conhecimento e às habilidades que a firma precisa.
\end{tabular}

Quadro 2.1 - Tipologia do modelo de Ferdows

Fonte: Adaptado de Ferdows (1997).

Assim, temos duas classificações por papel estratégico que seria assumido pela planta.

Essas classificações apresentariam competências distintas que as identificariam. O quadro 2.2 destaca como cada uma dessas seis classificações se posiciona em relação às duas dimensões do modelo. 


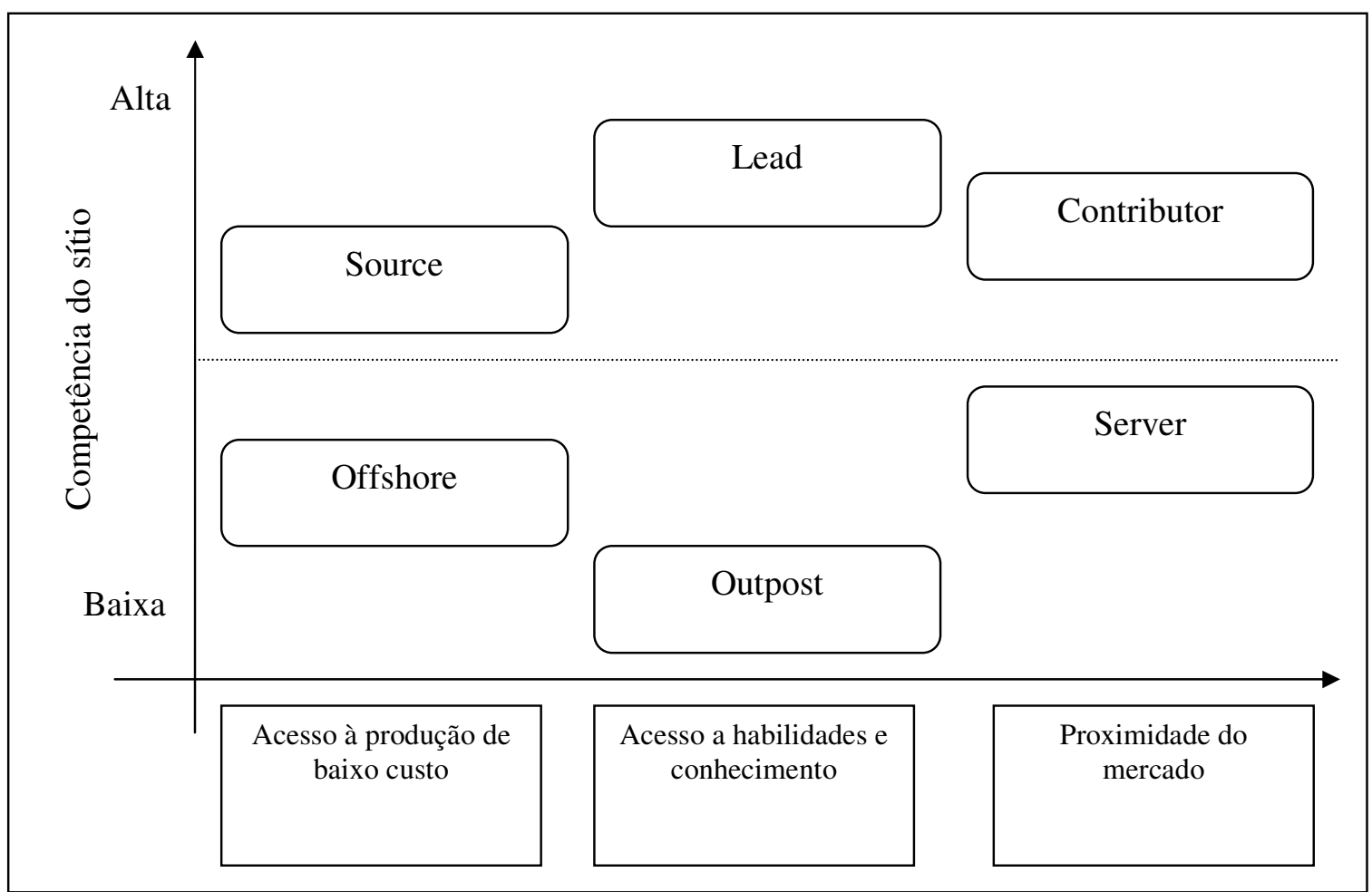

Quadro 2.2 - Competência do sítio versus estratégia da planta.

Fonte: Adaptado de Ferdows (1997)

Assim, as plantas com competências mais altas se classificariam como Source, Lead ou Contributor. E as com competências mais baixas poderiam ser classificadas como Offshore, Outpost ou Server. Contudo, vale ressaltar que uma mesma planta pode combinar dois ou mais papéis estratégicos (FERDOWS, 1997).

\subsubsection{Segunda proposição do estudo de caso}

Ao determinar sua estratégia de internacionalização, a empresa multinacional deve contemplar o impacto desta em suas funções. Assim, é necessária uma concordância entre a estratégia global da empresa e sua estratégia específica de P\&D. Considerando isso, foi levantada a seguinte proposição $(P 2)$ : 
P2: Nas multinacionais brasileiras estudadas há uma consonância entre a estratégia global da empresa e sua estratégia de P\&D.

\subsection{A FUNÇÃO DE PESQUISA E DESENVOLVIMENTO (P\&D)}

Um aspecto crucial do processo de globalização das atividades organizacionais é o incremento de atividades tecnológicas realizadas no exterior. A aceleração do progresso tecnológico, o aumento da especialização das atividades de P\&D e a divisão internacional do trabalho de pesquisa trazem à tona novos conhecimentos, tecnologias e recursos que são produzidos em bolsões de inovação espalhados pelo globo. Esta é a principal razão de se internacionalizar o P\&D (CHIESA, 1995). Porém, antes de entrar na internacionalização de $\mathrm{P} \& \mathrm{D}$ propriamente dita, faz-se necessário apresentar o conceito de $\mathrm{P} \& \mathrm{D}$.

\subsubsection{A definição de P\&D}

O P\&D é compreendido como o trabalho criativo sistêmico para aumentar o estoque de conhecimento, e inclui o conhecimento do homem, cultura e sociedade, e o uso desse estoque para criar novas aplicações (OECD, 2002). Além de gerar novos conhecimentos, as atividades de $\mathrm{P} \& \mathrm{D}$ também são responsáveis pela capacidade da firma de assimilar e utilizar o conhecimento já existente (LIYANAGE; GREENFIELD; DON, 1999).

Porém, nessa era de difusão rápida do conhecimento, o P\&D é mais do que o processo de gerar, desenvolver e difundir novos conhecimentos para o desenvolvimento de produtos, 
processos e serviços. O conhecimento adquirido por meio de pesquisa e observações racionais contribui de forma única para o sistema que forma a base de suporte a vantagens competitivas. Assim, o $\mathrm{P} \& \mathrm{D}$ atualiza os conceitos organizacionais com o conhecimento contemporâneo e o estado-da-arte (LIYANAGE; GREENFIELD; DON, 1999).

\subsubsection{A divisão do P\&D}

O P\&D é composto pelas funções de pesquisa e de desenvolvimento experimental. A pesquisa é dividida em três subconjuntos: básica, básica orientada e aplicada. A pesquisa básica é o trabalho teórico ou experimental realizado com o objetivo primordial de adquirir um novo entendimento dos fundamentos por trás de um fenômeno ou fatos observados, sem ter em vista qualquer aplicação ou uso particular (OECD, 2002).

Porém, existem momentos em que essa pesquisa básica pode apresentar um uso particular e passa a ser, então, uma pesquisa básica orientada. Esta é realizada com a expectativa de que irá produzir um amplo conjunto de conhecimento capaz de formar uma base para as soluções dos problemas atuais ou futuros (OECD, 2002). A pesquisa básica é fonte de novas tecnologias revolucionárias que terminam por mostrar oportunidades de novos negócios (LIAO; GREENFIELD, 1998), servindo como plataforma para o subseqüente desenvolvimento de produtos comercialmente viáveis e processos de fabricação (MEDCOF, 1997). A pesquisa aplicada é uma investigação original conduzida de forma a adquirir um novo conhecimento. Entretanto, é quase sempre direcionada a um objetivo prático (OECD, 2002), focado na inovação de produtos e processos (LIAO; GREENFIELD, 1998).

Por sua vez, o desenvolvimento experimental é o trabalho sistemático de aplicação do

conhecimento gerado, a partir da pesquisa e da experiência prática. É direcionado para a produção de novos materiais, produtos e aparelhos; para a instalação de novos processos, 
sistemas e serviços; ou para o aprimoramento substancial daqueles já produzidos ou instalados (OECD, 2002). Pode ser considerado, também, o processo de criação de novos produtos ou processos que apresentem viabilidade comercial, por meio da aplicação das plataformas ou conhecimentos científicos disponíveis atualmente (MEDCOF, 1997).

$\mathrm{Na}$ medida que as novas empresas começam a integrar seus processos em cadeias de inovação, a pesquisa básica também começa a ser contemplada e organizada, interagindo com a manufatura e o marketing. Por essa ótica, a relação entre pesquisa básica, desenvolvimento e inovação está passando por mudanças e, com isso, as empresas estão se deparando com formas não-convencionais de interface entre $\mathrm{P} \& \mathrm{D}$ básico e aplicado, e entre os conhecimentos privado e público (GERYBADZE; REGER, 1999).

\subsubsection{A terceira proposição do estudo de caso}

Após a visão geral do gerenciamento do P\&D da empresa, exposta na proposição anterior, o próximo passo é identificar quais e como são gerenciadas as atividades de desenvolvimento de produto realizado no Brasil. Essa análise servirá de ponto de partida para uma comparação com as atividades realizadas internacionalmente, tema da terceira proposição (P3):

P3: As multinacionais estudadas realizam atividades de desenvolvimento de produto no Brasil. 


\subsubsection{As quatro gerações do gerenciamento de P\&D}

Atualmente, o gerenciamento de P\&D está ligado à administração do conhecimento, ou seja, sua geração, proteção, aquisição, desenvolvimento e difusão. O gerenciamento do conhecimento é um fator de sucesso para a competitividade de um setor por meio da inovação contínua (LIYANAGE; GREENFIELD; DON, 1999). Ao mesmo tempo, o P\&D se mostrou como um dos fatores mais importantes para se obter inovações de sucesso (JANKOWSKY, 1998). Inovações que se tornaram mais orientadas para o mercado, mais relacionadas em redes de $\mathrm{P} \& \mathrm{D}$, e que aplicam as mais novas técnicas de gerenciamento de projeto (GROEN; et al., 2002). Além disso, com a internacionalização, o desafio para o gerenciamento é fazer a integração das unidades de $\mathrm{P} \& \mathrm{D}$ dispersas geograficamente, de maneira a torná-las parceiras produtivas dentro da rede de P\&D global da empresa (GASSMAN, VON ZEDWITZ, 2003).

Esse amadurecimento do gerenciamento do $\mathrm{P} \& \mathrm{D}$ deu-se com a percepção de que o processo de inovação não é linear, calmo e bem comportado, mas sim o oposto - complexo, incerto, desordenado e sujeito a mudanças. Assim, os modelos que delineavam a inovação como um processo linear, pecavam por não especificarem a natureza e a direção dos fatores de causa em ação (KLINE; ROSEMBERG; 1986). As próximas seções apresentam as quatro gerações de $\mathrm{P} \& \mathrm{D}$ na literatura, para uma melhor compreensão de como se deu seu desenvolvimento de gestão e de inovação.

\subsubsection{A primeira geração}

A primeira geração se desenvolveu no início da década de 1950, com duas características: a ênfase na criatividade individual, e a pesquisa científica realizada com controles burocráticos mínimos, ou seja, sua estratégia era de "science-push". O 
conhecimento era considerado um bem público, que podia ou não contribuir para o mercado. As unidades de P\&D eram estabelecidas com uma grande autonomia, ficando os pesquisadores responsáveis pela seleção e condução das pesquisas realizadas (LIYANAGE; GREENFIELD; DON, 1999). A estratégia da primeira geração consistia em um P\&D que operava isoladamente, com atividades não planejadas, e a tecnologia era o ativo que precisava ser gerenciado (ROGERS, 1996).

\subsubsection{A segunda geração}

A segunda geração, utilizada entre as décadas de 1960 e 1970, foi uma extensão da primeira. A ênfase era dada à natureza multidisciplinar do P\&D e à necessidade da seleção e gerenciamento dos projetos de forma profissional. Com isso, o projeto passa a ser o ativo gerenciado (ROGERS, 1996). Os pesquisadores eram compelidos a selecionar projetos que apresentassem resultados tangíveis dentro de um horizonte de tempo especificado. Foi nessa geração que surgiu a divisão das atividades de P\&D em pesquisa básica, pesquisa aplicada e desenvolvimento (LIYANAGE; GREENFIELD; DON, 1999).

\subsubsection{A terceira geração}

Na década de 1980, a terceira geração do P\&D toma uma forma estratégica e organizacional. Surge a noção de que o gerenciamento de $P \& D$ seria melhor se a sua estratégia fosse ajustada à estratégia corporativa (LIYANAGE; GREENFIELD; DON, 1999). Assim, em ambos os níveis organizacionais (estratégico e operacional), o departamento de P\&D tem de cooperar com outros departamentos da empresa, de forma a integrar os processos da empresa (KERSSENS-VAN DROGELEN; NIXON; PEARSON, 2000a). Esse modelo era 
bem ajustado às grandes corporações que precisavam de controles para gerenciar seu portfólio de P\&D (LIYANAGE; GREENFIELD; DON, 1999). Nessa geração, o negócio tornou-se o ativo a ser gerenciado (ROGERS, 1996).

As três gerações contribuíram para o desenvolvimento de técnicas e ferramentas de gerenciamento de P\&D. Contudo, esses modelos não eram focados no conhecimento global, na eficiência e eficácia da integração, e no gerenciamento de processos do conhecimento. Além disso, nas três gerações, não foi realizada nenhuma tentativa sistemática de explorar a interdependência entre os processos internos de P\&D e a difusão do conhecimento e tecnologia externos (LIYANAGE; GREENFIELD; DON, 1999). Considerando as lacunas descritas anteriormente, os autores conceituaram uma quarta geração de P\&D.

\subsubsection{A quarta geração de P\&D (LIYNAGE; GREENFIELD; DON, 1999)}

Atualmente, a gestão da inovação e do P\&D se reveste de um sentido mais amplo “...abrangendo todos os processos capazes de transformar uma idéia em um produto ou processo com diferencial de mercado, seja na indústria, nos serviços, comércio ou agricultura" (ARBIX, 2006: 16). Além disso, a globalização é uma das forças motrizes da rápida e contínua evolução tecnológica enfrentada pelas empresas (TAKAHASHI; TAKAHASHI, 2007).

Assim, a quarta geração de P\&D proposta por Liyanage, Greenfield e Don (1999) surge para lidar com o conhecimento externo à empresa. Dessa forma, ela comporta os seguintes processos de $\mathrm{P} \& \mathrm{D}$ : absorção do conhecimento externo à empresa, integração de habilidades e recursos complementares como forma de diminuir os custos de $\mathrm{P} \& \mathrm{D}$, e gerenciamento do conhecimento, tratando-o como um ativo intelectual. Essa geração concentra seus esforços em três requisitos: criatividade, redes e utilização do conhecimento. 
As empresas precisam ampliar o conceito de gerenciamento do conhecimento, inovação e tecnologia. Além da simples aquisição de tecnologia, a estratégia da empresa deve contemplar fatores exógenos e endógenos de utilização, produção e difusão do conhecimento (LIYANAGE; GREENFIELD; DON, 1999). Essa quarta geração segue as tendências recentes de esforços de colaboração, terceirização, alianças, redes e a adoção da organização virtual, procurando conduzir atividades de $\mathrm{P} \& \mathrm{D}$ não apenas mais eficientes, mas também mais eficazes (KERSSENS-VAN DROGELEN; NIXON; PEARSON, 2000b). Surge, com essa geração, a dúvida de como a empresa poderia gerenciar o $\mathrm{P} \& \mathrm{D}$ realizado em múltiplas unidades dispersas geograficamente. A quarta geração está ligada a uma nova visão da internacionalização de $\mathrm{P} \& \mathrm{D}$ e, portanto, esse tópico será abordado na próxima seção.

\subsection{INTERNACIONALIZAÇÃO DE P\&D}

A internacionalização do P\&D industrial pode ser interpretada como uma tentativa de empresas intensivas em tecnologia, de explorar vantagens específicas de localização, de forma a competir em um ambiente cada vez mais globalizado (GASSMANN; VON ZEDWITZ, 2002). Retomando a definição de Welch e Luostarinen (1988), pode-se afirmar que a internacionalização de P\&D é o envolvimento da empresa com atividades internacionais relacionadas à geração, desenvolvimento, proteção, difusão e aquisição de conhecimento e tecnologia, procurando por vantagens competitivas.

\subsubsection{Um fenômeno recente}

Já faz algum tempo que as empresas internacionalizam suas atividades de marketing e produção, mas a internacionalização de $\mathrm{P} \& \mathrm{D}$ é um fenômeno recente (GAMMELTOFT, 
2005). Tradicionalmente, as multinacionais sempre retiveram sua função $P \& D$ perto da matriz, e o argumento utilizado era o da preocupação com a segurança em relação ao conhecimento gerado. Assim, com a finalidade de proteger os ativos cruciais para sua competitividade, as empresas preferiam utilizar laboratórios localizados em seus países de origem. Um outro argumento era de que o P\&D centralizado possibilitava atingir economias de escala uma vez que a descentralização aumenta os custos de coordenação e de controle, tornando a comunicação mais difícil (CHIESA, 1995; BLANC; SIERRA, 1999). Gammeltoft (2005) acrescenta que, ao conservarem o P\&D em seu país de origem, as multinacionais mantinham a proximidade entre a área estratégica e o desenvolvimento de competências centrais; eram capazes de integrar os arranjos industriais específicos e os centros de conhecimento (universidades); mantinham ligações com os usuários principais, e reuniam a massa crítica necessária. Com isso, as empresas esperavam desenvolver vantagens competitivas - em especial o conhecimento tecnológico - em seu ambiente doméstico distinto, e explorar essa vantagem no exterior (REDDY, 1997).

Porém, a partir da década de 1980, a internacionalização de P\&D não parou de crescer, tanto quantitativamente quanto qualitativamente. Durante os primeiros períodos de expansão global (anos 1960 e 1970), as multinacionais constituíram unidades de venda e de manufatura em países estrangeiros. Nos anos 1970 e 1980, os esforços estavam direcionados para prover as subsidiárias de capacidades em design e desenvolvimento complementares (CHIESA, 2000). A partir dos anos 1980, devido à globalização, houve uma clara tendência para a realização de atividades de $\mathrm{P} \& \mathrm{D}$ em unidades no estrangeiro, apesar dessas atividades estarem, inicialmente, limitadas à engenharia e à adaptação de produtos e processos tecnológicos. De acordo com Chiesa (2000), esse movimento se deu porque a manufatura e o marketing, instalados no exterior, necessitavam de um suporte técnico. Além disso, a dispersão geográfica das instalações técnicas facilitava a penetração em mercados 
estrangeiros. Estrategistas suecos acrescentam como razões para internacionalização do P\&D, a falta de competências-chave no país de origem, a necessidade de melhor acesso à comunidade científica e tecnológica internacional, e o sistema de imposto inflexível da Suécia (GRANSTRAND; PAVEL; PAVITT, 1997).

Ronstadt (1978) notou que muitas das instalações de P\&D estrangeiras foram adquiridas acidentalmente, como parte de um processo de fusão ou aquisição. Ou seja, ao ocorrer a fusão ou a aquisição, a empresa "ganhava" uma função P\&D no exterior. Fato importante é que nenhuma dessas aquisições visava obter acesso aos recursos de P\&D da organização adquirida (RONSTADT, 1978). Dessa forma, a internacionalização de P\&D pode ser o produto da intensificação das atividades de fusões e aquisições (F\&A), ou o produto de uma internacionalização intencional, devido a fatores organizacionais (VON ZEDWITZ, 2005).

\subsubsection{O crescimento da internacionalização na década de 1990}

Os anos 1990 foram caracterizados pelo crescimento da internacionalização de P\&D, em que as empresas perseguiram as oportunidades de expansão (GASSMANN; VON ZEDWITZ, 1999), incluindo a montagem de laboratórios em países estrangeiros, o que resultou em um rápido crescimento dessa atividade no exterior. A literatura recente em internacionalização de tecnologia assinala que as maiores empresas do mundo têm aumentado suas atividades de P\&D e de inovação fora dos países de origem (PATEL; LE BAS, 2005). Esse aumento levou a um novo movimento no estabelecimento de configurações multinacionais de P\&D (GERYBADZE; REGER, 1999), com processos de ciência, tecnologia e inovação cada vez mais dispersos, tanto geográficos quanto funcionalmente (GAMMELTOFT, 2005). 
De acordo com Chiesa (2000), as empresas reconheceram que habilidades e talentos especializados, produtores de novas tecnologias ou de novos conhecimentos, se desenvolvem localmente, perto de centros de excelência ao redor do mundo. As firmas se viram forçadas a dispersar suas unidades de P\&D para acessar tal conhecimento. Por isso, a capacidade inovadora dessas firmas começou a depender da sua habilidade de capitalizar os recursos e o empreendedorismo de suas diversas subsidiárias, de integrar os recursos e capacidades de suas diferentes unidades, e de equilibrar seus recursos específicos, com o objetivo de gerar inovações que pudessem ser exploradas globalmente (CHIESA, 2000).

Assim, organizações globais de P\&D foram criadas na forma de unidades dispersas, cada qual com um propósito definido, direcionadas pelas estratégias globais da empresa. O sucesso dos projetos globais dependia de como a estrutura de P\&D global era apoiada pelas ferramentas e mecanismos organizacionais. Por exemplo, um dos elementos centrais na organização e gerenciamento das estruturas globais de P\&D, era a política global de recursos humanos. Ou seja, o recrutamento de especialistas para novas vagas, o desenvolvimento de carreiras que envolvessem experiências multinacionais, e um sistema de recompensa comum tanto no nível local, quanto no nível global (CHIESA, 2000). Assim, com a globalização do P\&D, a empresa passa a contemplar, também, a inclusão dos esforços de obter acesso a técnicos, pesquisadores e cientistas nos países para onde se internacionaliza (REDDY, 1997).

\subsubsection{A “estagnação quantitativa"}

Após a rápida internacionalização de $\mathrm{P} \& \mathrm{D}$ ocorrida nas duas últimas décadas, há indícios de que esse fenômeno pode ter entrado em um estágio de consolidação (OECD, 2004). Essa "estagnação quantitativa" estaria acontecendo - apesar das unidades autônomas e descentralizadas serem flexíveis, rápidas e conscientes das demandas locais - porque os 
resultados das estruturas internacionais de $\mathrm{P} \& \mathrm{D}$ tornaram-se complexos, fragmentados e de difícil gerenciamento (GERYBADZE; REGER, 1999).

Mesmo na era da informação global e dos sistemas de comunicação, o gerenciamento eficiente das unidades de P\&D e de projetos dispersos geográfica, cultural e institucionalmente, não é trivial (GERYBADZE; REGER, 1999). É verdade que as modernas tecnologias de informação e comunicação reduzem a necessidade de que as atividades de projeto sejam realizadas na mesma localidade, mas não resolve os problemas relacionados à confiança, espírito de equipe e transferência de conhecimento tácito (GASSMAN; VON ZEDWITZ, 2003). Isso levou as empresas a consolidar e reorganizar suas operações, reafirmando a necessidade de coordenação e controles hierárquicos (GAMMELTOFT, 2005). Uma das formas encontradas pelas empresas para se reorganizar foi a manutenção de múltiplos centros de aprendizado, mas sob o controle de um centro de coordenação (GERYBADZE; REGER, 1999; CHIESA, 1995).

Diante do exposto, têm-se dois momentos distintos de internacionalização de P\&D. O primeiro, entre as décadas de 1980 e 1990, quando houve a dispersão dessas atividades no âmbito global. O segundo, a partir do fim da década de 1990, é caracterizado por uma conscientização de que esse crescimento precisava de um melhor gerenciamento. Esses dois momentos são descritos por Gerybadze e Reger (1999) como o da a visão tradicional e o do novo paradigma da internacionalização de $\mathrm{P} \& \mathrm{D}$.

\subsubsection{Visão tradicional}

$\mathrm{Na}$ visão tradicional, o papel das multinacionais era, quase exclusivamente, gerar os conhecimentos tecnológicos de produtos e processos em sua matriz. O conhecimento gerado era então transferido para as atividades de vendas e produção no estrangeiro. Era uma via de 
mão-única de transferência tecnológica, tipicamente envolvendo fluxos de informação provenientes do centro para a periferia (GERYBADZE; REGER, 1999). Outra característica, era que cada campo tecnológico tendia a ser dominado por um centro global de pesquisa e inovação, tipicamente nos EUA (GAMMELTOFT, 2005).

\subsubsection{O novo paradigma da internacionalização de P\&D}

O novo paradigma enfatiza os caminhos pelos quais os processos de conhecimento e de inovação tornam-se, cada vez mais, policêntricos. O P\&D internacionalizado não está mais preocupado somente em adaptar produtos às preferências locais ou adaptar processos produtivos à tecnologia local e fatores mercadológicos. Ao contrário, as empresas multinacionais internacionalizam seu $\mathrm{P} \& \mathrm{D}$ também com o objetivo de monitorar novos desenvolvimentos tecnológicos, gerar novas tecnologias e produtos nas instalações no exterior, e convertê-las, o mais rápido possível, em novos negócios de sucesso (GERYBADZE; REGER, 1999; GAMMELTOFT, 2005).

\subsubsection{O conhecimento como vantagem competitiva}

Dessa forma, os motivos para conduzir atividades tecnológicas passaram a contemplar, também, o acesso ao conhecimento e às habilidades nas áreas de rápido desenvolvimento tecnológico (PATEL; LE BAS, 2005). Criar e manter uma vantagem competitiva tecnológica requer aumentos no acesso a uma gama mais ampla de habilidades e conhecimentos técnicos e científicos do que os disponíveis no país de origem (BLANC; SIERRA, 1999). 
2.3.5.2 Dispersão de atividades em escala mundial

Esse paradigma está construído na multiplicidade e dispersão de competências em escala global, sendo motivado tanto pela pesquisa quanto pelo mercado. Assim, as multinacionais precisam estabelecer mecanismos internos de transferência de conhecimento mais eficientes, já que estes contribuem para acelerar a conversão do conhecimento em produtos comercializáveis, aumentando a interatividade entre os sistemas de mercado e de pesquisa, e a efetiva integração intracorporativa dos múltiplos centros de aprendizado. Tornase, portanto, uma via de mão-dupla de aprendizado, possibilitando uma transferência de tecnologia nos dois sentidos e de forma interativa, tanto entre localidades geográficas diferentes, quanto entre unidades organizacionais (GERYBADZE; REGER, 1999).

\subsubsection{As redes de P\&D internacional}

As multinacionais não estão restritas somente a uma dicotomia de escolhas - ficar em casa ou alocar-se no exterior - para adquirir fontes de conhecimento imóveis. Existe uma variedade de opções disponíveis para acessar recursos específicos advindos da localização, e estes incluem acordos cooperativos. Tais acordos proporcionam acesso a tecnologias que são específicas de outras empresas (NARULA; DUYSTERS, 2004). As multinacionais aprimoram, dessa forma, suas capacidades de absorção de conhecimento por meio de um portfólio de projetos colaborativos e redes. Com a cooperação e alianças estratégicas de $\mathrm{P} \& \mathrm{D}$, as empresas líderes em tecnologia criaram novas soluções que propiciaram a rápida construção de redes flexíveis das competências dispersas regionalmente ou institucionalmente. Isso inclui novas formas de distribuir as atividades de P\&D e competências entre fornecedores, consumidores, e ainda entre universidades e institutos de 
pesquisa (GERYBADZE; REGER, 1999). Narula e Duyster (2004) sugerem que uma característica importante dessas alianças é que seu uso é disperso entre as firmas, independente de nacionalidade e porte, em atividades diversas, mesmo as que antes eram centralizadas e internalizadas como o P\&D (NARULA; DUYSTERS, 2004; GERYBADZE; REGER, 1999).

\subsubsection{A heterogeneidade da internacionalização de P\&D}

A internacionalização do $\mathrm{P} \& \mathrm{D}$ industrial é um fenômeno recente, que ainda não progrediu muito em termos absolutos. Entretanto, existem algumas tendências claras de que a longo prazo haverá um aumento na importância do $\mathrm{P} \& \mathrm{D}$ conduzido em bases internacionais (BLANC; SIERRA, 1999). A dispersão geográfica das atividades de P\&D pode fortalecer a base tecnológica das empresas, possibilitando-lhes o acesso a tecnologias mais avançadas e, também, a aumentar sua escala de produção, o que dilui os custos com P\&D. Ou seja, empreendimentos maiores, via internacionalização, possibilitam diminuir os custos de prospecção tecnológica e, conseqüentemente, os gastos com P\&D (ALEM; CAVALCANTI, 2005).

Ao mesmo tempo, a internacionalização de $\mathrm{P} \& \mathrm{D}$ ainda não pode ser associada a uma distribuição global homogênea das atividades de inovação (GERYBADZE; REGER, 1999; BLANC; SIERRA, 1999), já que ainda existe uma forte concentração de P\&D internacionalizado nos países da Tríade, na Coréia do Sul, em Cingapura e em outras economias emergentes do Pacífico (GASSMANN; VON ZEDWITZ, 2002).

Na figura 2.1 temos a distribuição de 1021 instalações de pesquisa e desenvolvimento levantadas por Gassmann e Von Zedwitz (2002). Percebe-se a concentração de instalações de pesquisa e desenvolvimento nos países da Tríade. As instalações destacadas por círculos 
brancos representam unidades de pesquisa, enquanto que as destacadas por quadrados pretos representam unidades de desenvolvimento. Os valores dentro das representações gráficas apontam o número mínimo de unidades por localidade.

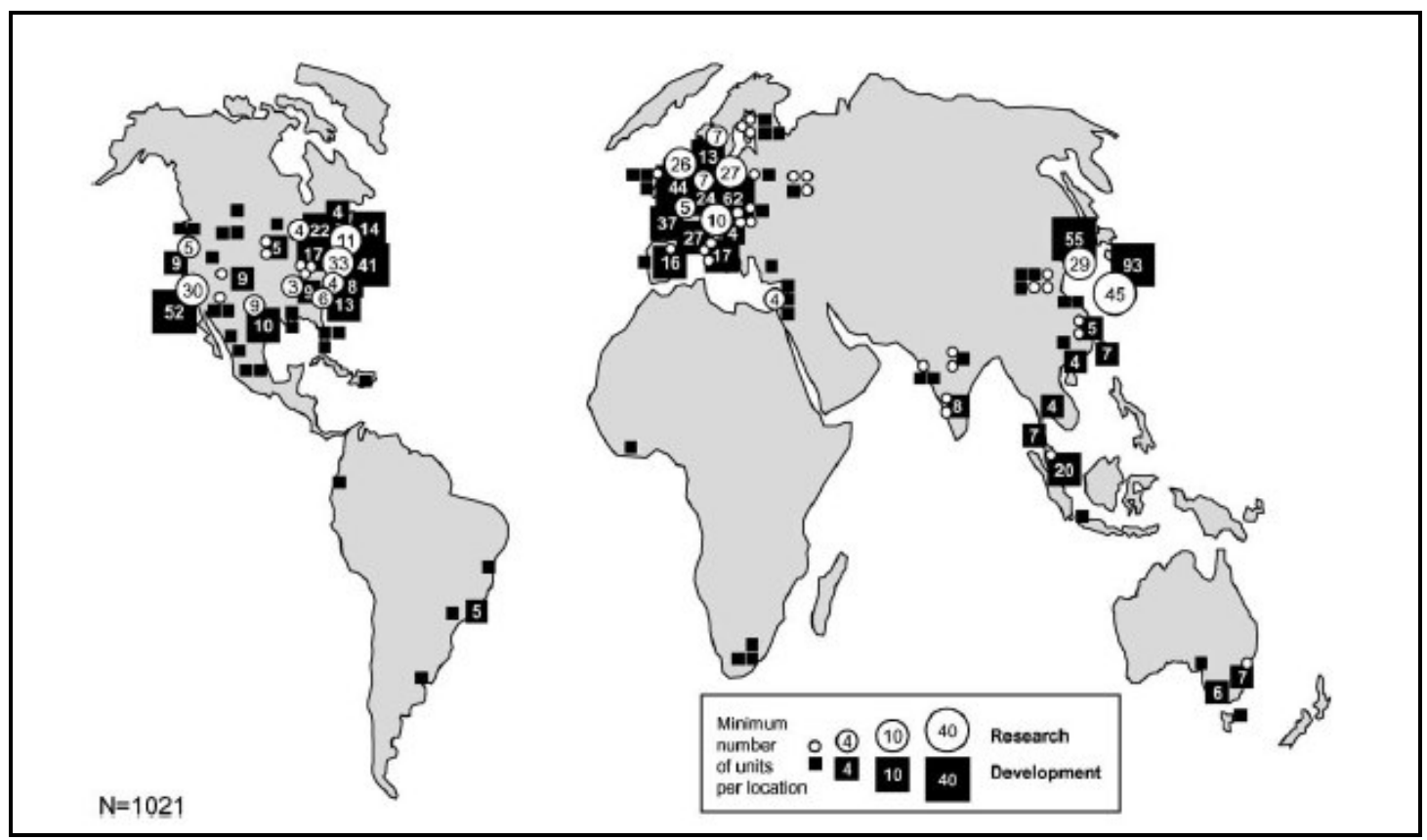

Figura 2.1 - Concentração de instalações de P\&D

Fonte: Gassmann e Von Zedwitz, 2002.

As atividades geradoras de conhecimento, cada vez mais efetuadas no estrangeiro, concentram-se em centros de excelência e, com isso, os processos mais sofisticados de P\&D que requerem tecnologia e conhecimento de ponta, tendem a se concentrar em países desenvolvidos (GERYBADZE; REGER, 1999). Uma possível explicação para esse fato, é que a internacionalização de $\mathrm{P} \& \mathrm{D}$ era realizada por multinacionais originárias de países desenvolvidos, e que tinham como destino outros países desenvolvidos. Von Zedwitz (2005) aponta esse como o tipo mais comum de internacionalização.

Mesmo com essa concentração nos países da Tríade, as empresas multinacionais instalam suas principais atividades inovadoras e de P\&D nos países de origem, limitando essas atividades no exterior. As evidências indicam que apenas cerca de $10 \%$ dos esforços 
tecnológicos são realizados nos países anfitriões (ARCHIBUGI; PIETROBELLI, 2003). Por outro lado, ainda não foi estudada em detalhes a extensão com a qual as firmas de países em desenvolvimento articulam suas capacidades inovadoras e criam suas redes globais de P\&D (VON ZEDWITZ, 2005).

\subsubsection{Atividades de P\&D realizadas em países em desenvolvimento}

A geração de novas tecnologias e inovações em países em desenvolvimento por multinacionais de países desenvolvidos, é ainda pouco significativa e não representa mais do que $1 \%$. Essas empresas não consideram conveniente alocar atividades tecnológicas em países em desenvolvimento, mesmo que as recompensas sejam significativas (ARCHIBUGI; PIETROBELLI, 2003). Existem, no entanto, algumas exceções, como o de multinacionais líderes no campo da tecnologia da informação e comunicação (Texas Instruments, Microsoft) que alocaram instalações de P\&D na Índia. Isso foi facilitado pela presença de universidades de renome, pela disponibilidade de engenheiros qualificados, e pela existência de uma estrutura de atividades produtivas relacionadas (ARCHIBUGI; PIETROBELLI, 2003).

\subsubsection{Estudos acadêmicos conduzidos em países em desenvolvimento}

Muitas das pesquisas sobre internacionalização de $\mathrm{P} \& \mathrm{D}$ foram realizadas em países desenvolvidos, pois estes eram responsáveis pela maior parte do P\&D conduzido globalmente, e estavam predispostos a cooperar. Já o P\&D realizado em países em desenvolvimento era pouco significativo em escala, e com dados escassos e dispersos (VON ZEDWITZ, 2005). 
Ao mesmo tempo, as multinacionais líderes de países em desenvolvimento tendem a ter baixa intensidade tecnológica e atuam em setores de exploração de recursos naturais (VON ZEDWITZ, 2005). No entanto, há excessões, e algumas dessas multinacionais perseguem um P\&D de alto nível internacional, como a Embraer no Brasil (o terceiro maior fornecedor mundial de aeronaves regionais), a Huawei (líder em telecomunicações da China), e a Infosys (provedora global de serviços de TI da Índia) (VON ZEDWITZ, 2005).

Von Zedwitz (2005), identificou duas estratégias possíveis para as empresas multinacionais de países emergentes internacionalizarem seu P\&D:

a) quando elas conduzem atividades de P\&D em um país de tecnologia avançada, e têm, por motivação principal, alcançar os níveis tecnológicos daqueles países. Estas firmas são naturalmente atraídas para usar países desenvolvidos como bases de $\mathrm{P} \& \mathrm{D}$, tanto para adquirir conhecimentos de ciência e tecnologia locais, quanto para apoiar o desenvolvimento de produtos locais.

b) a segunda estratégia seria quando essas multinacionais investem em $P \& D$ em outro país em desenvolvimento. As razões podem ser o apoio da transferência de tecnologia de segundo geração (quando um país recebeu tecnologia anteriormente e agora passa para outro), ou para oferecer apoio a outras atividades organizacionais.

Esses dois tipos de internacionalização de P\&D ainda não estão bem entendidos e, até certo ponto, contradizem as visões estabelecidas de P\&D internacional (VON ZEDWITZ, 2005). 


\subsubsection{Modelos de internacionalização de P\&D}

Nesta seção, serão apresentados três modelos que serão utilizados para analisar o P\&D dos casos estudados. O primeiro é o de Gassman e Von Zedwitz (1999) que considera a gestão de P\&d internacionalizado, sua coordenação e configuração. O segundo, o modelo de Chiesa (1995), avalia o centro de gravidade do P\&D de uma empresa, indicando se este se concentra em pesquisa ou em desenvolvimento. Por fim, o terceiro é o modelo Ronstadt e Reddy $(1977 ; 1997)$ que analisa as atividades de P\&D realizadas em cada unidade no exterior.

\subsubsection{Modelo de gestão de P\&D internacionalizado}

Apesar de apresentarem reservas com relação à internacionalização da função $P \& D$, devido aos seus altos custos de execução e baixa eficiência de projeto, as empresas reconhecem que o potencial do $\mathrm{P} \& \mathrm{D}$ internacional tem sido subestimado e insuficientemente explorado (GASSMANN; VON ZEDWITZ, 2002). As empresam internacionalizam seu P\&D por razões de demanda e de tecnologia. Os fatores de demanda incluem a obtenção de acesso aos mercados, resposta a necessidades locais específicas, e aumento da proximidade com consumidores. Já os fatores de tecnologia, são: acesso à tecnologia externa, recrutamento de pessoal qualificado e acesso a talentos estrangeiros, tanto empresariais quanto técnicos (CHIESA, 1995).

Ao analisar os benefícios e as ameaças da internacionalização de $\mathrm{P} \& \mathrm{D}$, cada empresa decide pela centralização ou pela descentralização da função. Sobre essa decisão, Gassmann e Von Zedtwitz (1999), em um estudo envolvendo 24 multinacionais de países desenvolvidos, identificaram cinco modelos diferentes de configurações de internacionalização de $\mathrm{P} \& \mathrm{D}$, a saber: o P\&D centralizado etnocentricamente; o P\&D centralizado geocentricamente; o P\&D 
descentralizado policentricamente; o P\&D organizado em hub; e o P\&D integrado em rede (ver quadro 2.3). Para cada configuração, foram levadas em consideração as seguintes variáveis: grau de centralização da tomada de decisão, e grau de cooperação/competição entre as subsidiárias da empresa.

\begin{tabular}{|c|c|c|}
\hline Modelo de P\&D & Configuração & Exemplos de Empresas \\
\hline $\begin{array}{c}\text { Centralizado } \\
\text { etnocentricamente }\end{array}$ & P\&D centralizado na matriz & Microsoft \\
& Programa de P\&D central com controle e \\
coordenação rígidos & Volvo \\
\hline Centralizado & P\&D centralizado na matriz & Nissan \\
geocentricamente & Contato próximo com sítios locais & MTU \\
& Recrutamento e rotação de trabalhos & ATR \\
& internacionais & ETL \\
& P\&D descentralizado & Kubota \\
\hline pescentralizado & Dominância de P\&D relacionado ao & Philips (anos 1980) \\
& produto & Sulzer \\
& Pouca coordenação entre as unidades de & Schindler (anos 1980) \\
& Poyal Dutch/Shell \\
\hline Organizado em hub & Orientação etno ou geográfica & BASF \\
& Estruturas de nódulos com clara & Zeneca \\
& dominância central & Siemens \\
& Cooperação entre unidades controlada & Bosch \\
& centralmente & Sony \\
\hline Integrado em rede & P\&D altamente internacionalizado & ABB \\
& Responsabilidade global dos centros de & Philips \\
& competências por tecnologias ou produtos & IBM \\
& Informação e coordenação multi- & Roche \\
& dimensionais & Ciba Geigy \\
& & Hoechst \\
\hline
\end{tabular}

Quadro 2.3 - Modelo de Gassmann e Von Zedtwitz para a internacionalização de P\&D

Fonte: Adaptado de Gassmann e Von Zedtwitz (1999).

\subsubsection{O modelo de Chiesa - O centro de gravidade de P\&D}

No início, a internacionalização do $\mathrm{P} \& \mathrm{D}$ era, principalmente, o resultado dos desenvolvimentos ou das ações acidentais e não relacionados diretamente com alguma estratégia de P\&D (RONSTADT, 1978; CHIESA, 1995). Contudo, atualmente, a internacionalização de P\&D está aumentando como resultado de deliberações estratégicas e como um fator-chave para aumentar a capacidade da firma de inovar (CHIESA, 1995). Segundo o autor, isso resulta de três motivos principais: as características da dinâmica 
tecnológica atual, a inovação que está se tornando sistêmica, e a pressão para reduzir o tempo dos lançamentos de novos produtos (CHIESA, 1995).

Dessa forma, existiriam duas abordagens para a internacionalização do P\&D: na primeira, o P\&D seria descentralizado como resultado da construção de laboratórios geograficamente dispersos, trabalhando a partir de um programa de pesquisas gerenciado centralmente. Na segunda, as empresas teriam seu P\&D descentralizado, seguindo a internacionalização da produção e do marketing para fornecer suporte tecnológico. Essas duas abordagens dependeriam do enfoque estratégico dado pela empresa à sua função, ou seja, seu “centro de gravidade” de P\&D (CHIESA, 1995).

A cada uma dessas abordagens estaria atrelado um tipo de organização. O primeiro tipo compreenderia as organizações voltadas para o "upstream" do P\&D. Ou seja, teriam sua competência na habilidade de desenvolver tecnologias que geram correntes de inovação a partir de suas próprias pesquisas. Estas organizações seriam orientadas à pesquisa e estariam ligadas a abordagem de um $\mathrm{P} \& \mathrm{D}$ descentralizado, trabalhando em um mesmo programa de pesquisa. Nessas empresas, os laboratórios de pesquisa ficariam centralizados, e só seriam descentralizados para acelerar o aprendizado por meio do acesso a recursos específicos. Já seus laboratórios de desenvolvimento seriam descentralizados para diminuir os custos de transferência do P\&D para a produção.

Já o segundo tipo de organização seriam aquelas focadas no "downstream” do P\&D. Essas organizações estariam voltadas para o desenvolvimento, baseando sua competência na habilidade de explorar e aplicar a tecnologia em novos produtos e processos (CHIESA, 1995). Nessas empresas, seus laboratórios de pesquisa seriam descentralizados para monitorar o desenvolvimento tecnológico e realizar pesquisas em conjunto. No entanto, seus laboratórios de desenvolvimento ficariam centralizados e só seriam descentralizados para acelerar o aprendizado sobre o mercado. 
2.3.9.3 Tipos de unidades de P\&D no exterior - modelo de Reddy (1997)

As MNC mantinham seu P\&D tradicionalmente confinado em seus países de origem. Em seus ambientes domésticos, esperavam desenvolver vantagens competitivas, em especial o conhecimento tecnológico, e explorar essas vantagens no exterior. Contudo, existiam algumas atividades de $\mathrm{P} \& \mathrm{D}$ realizadas no exterior, como as adaptações ou, em alguns casos, o desenvolvimento de produtos para mercados locais (REDDY, 1997).

Ronstadt (1978) distinguiu quatro tipos diferentes de unidades de P\&D utilizados por multinacionais norte-americanas, cada uma apresentando funções e atendendo a mercados específicos (ver quadro 2.4)

\begin{tabular}{|c|l|}
\hline \multicolumn{1}{|c|}{ Tipo de Unidade } & \multicolumn{1}{c|}{ Função } \\
\hline Unidade de transferência de tecnologia & $\begin{array}{l}\text { Facilitar a transferência de tecnologia da } \\
\text { matriz para a subsidiária, e prover serviços } \\
\text { técnicos locais. }\end{array}$ \\
\hline Unidade de tecnologia nativa & $\begin{array}{l}\text { Desenvolver novos produtos para os } \\
\text { mercados locais a partir da tecnologia local. }\end{array}$ \\
\hline Unidades de tecnologia global & $\begin{array}{l}\text { Desenvolver novos produtos e processos } \\
\text { para a maioria dos mercados do mundo. }\end{array}$ \\
\hline Unidade de tecnologia corporativa & $\begin{array}{l}\text { Gerar tecnologia básica a longo prazo ou de } \\
\text { natureza exploratória para ser utilizada pela } \\
\text { matriz. }\end{array}$ \\
\hline
\end{tabular}

Quadro 2.4 - As funções das unidades no exterior

Fonte: Adaptado de Ronstadt (1978)

Contudo, os mercados mundiais começaram a se integrar, em termos de padrões e tecnologias, surgindo os aglomerados regionais. Nesses aglomerados regionais, os mercados regionais dividem características comuns e necessidades por produtos especializados. Considerando isso, Reddy e Sigurdson (1994 apud REDDY, 1997) adicionaram mais um tipo de unidade ao trabalho de Ronstadt (1978), a unidade de tecnologia regional. 


\begin{tabular}{|c|l|}
\hline Tipo de unidade & \multicolumn{1}{c|}{ Função } \\
\hline Unidade de tecnologia regional & $\begin{array}{l}\text { Desenvolver produtos e processos para os } \\
\text { mercados regionais. }\end{array}$ \\
\hline
\end{tabular}

Quadro 2.5 - A função da unidade de tecnologia regional

Adaptado de Reddy (1997)

\subsubsection{A quarta proposição do estudo de caso}

Diante do exposto, a quarta proposição é que a empresa multinacional dispersa suas unidades de P\&D globalmente. Para verificar esta proposição, serão utilizados os modelos referenciados anteriormente.

P4: A empresa multinacional internacionaliza seu desenvolvimento de produto, dispersando suas unidades de P\&D globalmente.

\subsection{DESENVOLVIMENTO GLOBAL DE PRODUTOS}

As empresas multinacionais são agentes da globalização da produção, que é a capacidade que essas empresas têm de montar suas instalações de manufatura em locais que ofereçam condições propícias. Essas condições podem ser baixos custos, alta qualificação da mão-de-obra, e facilidade de acesso à matéria-prima, entre outras (DIAS; GALINA, 2000).

Várias são as atividades que podem ser realizadas por instalações de P\&D no exterior (OGBUEHI; BELLAS JUNIOR, 1992). Primeiramente, elas podem desenvolver novos produtos, processos ou sistemas organizacionais localmente, usando seus próprios recursos técnicos e organizacionais para responder às circunstâncias locais. Podem, também, adaptar as inovações desenvolvidas pela matriz, pela instalação central de $\mathrm{P} \& \mathrm{D}$ ou, ainda, por outras 
subsidiárias para o mercado local. Finalmente, as subsidiárias podem, inclusive difundir suas inovações locais para a matriz ou outras subsidiárias (BARTLETT; GHOSHAL, 1988).

O desenvolvimento global de produtos é um dos grandes desafios que as empresas enfrentam atualmente. Quando feito corretamente, leva ao aumento de vendas e dos lucros, porém, quando incorreto, leva ao acúmulo de prejuízos e ao desperdício de recursos (GRABER, 1996). O correto gerenciamento do desenvolvimento global de produtos depende das características da empresa, e requer uma estrutura organizacional global formalizada, com dispositivos de controle e coordenação atuantes (GRABER, 1996) As multinacionais que desenvolvem produtos de sucesso e de forma consistente, geralmente são coerentes e integradas (ESTORILIO, 2003).

Uma particularidade da globalização é a oferta de produtos com uma mesma plataforma tecnológica, em diferentes mercados. Essa estratégia de produto global já é uma realidade, porém, pode não atender a certos mercados locais, devido a fatores naturais, sociais, econômicos, políticos ou legais (DIAS; GALINA, 2000). Portanto, um dos primeiros passos para o desenvolvimento de um produto global é decidir o quanto de comunalidade deve ser associada ao produto e quanto o mercado local necessita de adaptação. Um produto como a Coca-Cola, que mantém a mesma fórmula e a mesma embalagem, pode ser vendido em qualquer mercado do mundo. Outros produtos também podem ser vendidos mundialmente, porém, antes, devem passar por pequenas modificações e adaptações aos mercados locais. Existe ainda um terceiro tipo de produto que requer diversas variações, uma (ou mais) para cada mercado que atende (GRABER, 1996).

Para Graber (1996), os quatro pontos principais no gerenciamento do processo de desenvolvimento de um produto global, são:

1) Começar pelo cliente, para entender as diferenças e semelhanças entre os mercados. 
2) Não fazer o produto mais global do que ele realmente é. Um eficiente produto regional é melhor do que um produto global deficitário.

3) Utilização de times globais e multifuncionais.

4) Apoio da alta direção.

\subsection{MULTINACIONAIS DE PAÍSES EMERGENTES}

Até esse ponto, o referencial teórico explorou a importância da internacionalização, a função pesquisa e desenvolvimento, a internacionalização da pesquisa e do desenvolvimento e, por fim, o desenvolvimento global de produtos. Este tópico tem por finalidade apresentar a maneira como as multinacionais brasileiras estão atuando no mundo globalizado, face a internacionalização e a sua função $P \& D$.

Um relatório do Boston Consulting Group (BCG) (BOSTON CONSULTING GROUP, 2006) analisa as vantagens, estratégias e impactos das 100 maiores multinacionais das economias emergentes, e o assunto repercutiu de tal maneira que foi capa da revista BusinessWeek de julho de 2006.

These new contenders hail from seemingly unlikely places, developing nations such as Brazil, China, India, Russia, and even Egypt and South Africa. They are shaking up entire industries, from farm equipment and refrigerators to aircraft and telecom services, and changing the rules of global competition (EMERGING, 2006; p. 40)*.

Essas 100 empresas combinadas apresentam uma receita de 715 bilhões de dólares e uma taxa de crescimento anual de $24 \%$. Atualmente, $28 \%$ de suas receitas derivam de operações no exterior (BCG, 2006). Elas representam quase todos os setores: bens industriais,

\footnotetext{
* Estes novos competidores surgem de lugares inesperados, nações em desenvolvimento como Brasil, China, Rússia e até o Egito e África do Sul. Eles estão abalando setores inteiros, de equipamentos agrícolas e refrigeradores a aeronaves e serviços de telecomunicações, e mudando as regras da competição global (Tradução do autor).
} 
bens de consumo, extração de recursos e serviços tecnológicos. Setenta dessas empresas são da Ásia (44 da China e 21 da Índia) e 18 são da América Latina (BCG, 2006). Doze são as empresas consideradas brasileiras: Braskem, Companhia Vale do Rio Doce, Coteminas, Embraco, Embraer, Gerdau, Natura, Perdigão, Petrobrás, Sadia, Votorantim e WEG (EMERGING, 2006).

Essas multinacionais de países emergentes estão crescendo dez vezes mais rápido que o PIB americano, 24 vezes mais rápido que o do Japão e 34 vezes mais rápido que o da Alemanha. Seu lucro operacional combinado está estimado em 145 bilhões de dólares, equivalente a uma margem de $20 \%$ sobre suas vendas (BCG, 2006). De acordo com o relatório, essas multinacionais estão se globalizando e procurando crescer organicamente, pois seus mercados domésticos não apresentam a escala ou os recursos que permitam isso. $\mathrm{O}$ objetivo dessas empresas é, portanto, conseguir acesso a novos mercados ou a reservas de matéria-prima de longo-prazo (BCG, 2006).

\subsection{INTERNACIONALIZAÇÃO E P\&D EM EMPRESAS BRASILEIRAS}

\subsubsection{A internacionalização de empresas brasileiras}

De acordo com o censo de 2004, o volume total de investimentos brasileiros diretos no exterior alcançou US\$ 71 bilhões, o que representou um crescimento da ordem de $30 \%$ em relação a 2003. Porém, esse investimento ainda é realizado, preponderantemente, pelas instituições financeiras e por empresas que utilizam holdings para administração de seus negócios internacionais. Apenas uma parcela reduzida desse investimento é realizado por empresas manufatureiras (ALEM; CAVALCANTI, 2005). 
No debate sobre o tema, os críticos às políticas de apoio à internacionalização alegam como principais fatores negativos, a possibilidade de "exportação" de empregos; o prejuízo ao balanço de pagamentos, já que envolveria uma saída de divisas do país; e a possível redução dos níveis de investimento doméstico. Por outro lado, os defensores dessas políticas, apresentam como pontos favoráveis, a importância da internacionalização para a sobrevivência das multinacionais de capital nacional, o aumento da competitividade dos seus países de origem, e a importância da criação de multinacionais brasileiras para a redução da vulnerabilidade externa (ALEM; CAVALCANTI, 2005).

\subsubsection{O investimento em P\&D pelas empresas brasileiras}

Nos países membros da Organização para o Desenvolvimento e Cooperação Econômica (OECD, sigla em inglês), o setor empresarial responde por cerca de $63 \%$ do dispêndio total em P\&D. No Brasil, por outro lado, os gastos em P\&D feitos pelas empresas correspondem a, aproximadamente, $37 \%$ do total (ASSOCIAÇÃO NACIONAL DE PESQUISA, DESENVOLVIMENTO E ENGENHARIA DAS EMPRESAS INOVADORAS, 2004). Apesar do baixo percentual apresentado, essas empresas nacionais, em proporção a seus faturamentos, investem mais em $P \& D$ do que as filiais de empresas estrangeiras instaladas no país.

Nos anos 90, a estratégia de grande parte das empresas brasileiras consistia na importação de tecnologia - visando a manutenção da competitividade - e na concentração do seu P\&D para a sustentação das capacidades necessárias, dando continuidade a esse processo de dependência do conhecimento externo (CARVALHO et al., 2000). Porém, do ponto de vista do sistema de inovação brasileiro, essa importação de tecnologia estrangeira é pouco significante, a menos que venha acompanhada de políticas locais que promovam o 
aprendizado e o desenvolvimento de capital humano e de capacidades tecnológicas (ARCHIBUGI; PIETROBELLI, 2003). Alem e Cavalcanti (2005) acrescentam que essas políticas de apoio devem ter, como contrapartida, a exigência de geração de empregos no mercado doméstico; o aumento das exportações; a transferência de tecnologia via criação de escritórios de engenharia; e o aumento de gastos em P\&D.

\subsection{OS OBJETIVOS E AS PROPOSIÇÕES DO TRABALHO}

Nas seções anteriores deste capítulo, foram levantadas quatro proposições que estão vinculadas aos objetivos do trabalho. Com base nos vículos entre os objetivos e as proposições, foram construídos dois quadros sinópticos: um relativo ao objetivo geral (Quadro 2.6), e outro aos objetivos específicos (Quadro 2.7).

Como apresentado anteriormente, o objetivo geral do trabalho é analisar a internacionalização das atividades de desenvolvimento de produto nas empresas MNB selecionadas. Espera-se, com isso, estudar a existência de um vínculo entre a internacionalização da produção e o desenvolvimento de produtos globais, o que é considerado uma tendência mundial. Portanto, a primeira proposição $(P l)$ é que, seguindo a tendência mundial, as multinacionais brasileiras, após internacionalizarem seus processos produtivos, internacionalizaram, ou pelo menos consideraram internacionalizar, o seu desenvolvimento de produtos.

\begin{tabular}{|c|c|}
\hline Objetivo geral & Proposição \\
\hline $\begin{array}{c}\text { Analisar a internacionalização das } \\
\text { atividades de desenvolvimento de produto } \\
\text { nas empresas MNB selecionadas. }\end{array}$ & $\begin{array}{c}\text { P1: As MNB, após a internacionalização de seus processos } \\
\text { produtivos, internacionalizam também seu desenvolvimento } \\
\text { de produtos. }\end{array}$ \\
\hline
\end{tabular}


Para alcançar o objetivo geral, foram determinados três objetivos específios. O primeiro é identificar a estratégia de $\mathrm{P} \& \mathrm{D}$ adotada pela organização e, com isso, traçar um panorama da maneira como ela coordena, planeja, organiza e dirige o P\&D em âmbito geral. Quais são suas atividades de P\&D e como elas estão distribuídas geograficamente? Portanto, a segunda proposição $(P 2)$ pressupõe a necessidade de concordância entre a estratégia de internacionalização da empresa e sua estratégia de P\&D.

O segundo objetivo específico é verificar como estão estruturadas as atividades de desenvolvimento de produtos, como elas ocorrem no Brasil e como são gerenciadas. Portanto, a terceira proposição (P3) que é a de que suas atividades de desenvolvimento de produtos no Brasil.

O terceiro objetivo específico trata da internacionalização das atividades de desenvolvimento de produtos realizadas nas unidades produtivas estrangeiras. Assim, a proposição (P4), procura investigar se as empresas multinacionais brasileiras seguem a tendência mundial, internacionalizando seu desenvolvimento de produtos.

\begin{tabular}{|c|c|}
\hline Objetivos específicos & Proposições do estudo de caso \\
\hline $\begin{array}{l}\text { Identificar a estratégia de } P \& D \text { adotada } \\
\text { pela empresa. }\end{array}$ & $\begin{array}{c}\text { P2: Nas multinacionais brasileiras estudadas há uma } \\
\text { consonância entre a estratégia global da empresa e sua } \\
\text { estratégia de } P \& D \text {. }\end{array}$ \\
\hline $\begin{array}{l}\text { Verificar como estão estruturadas } \\
\text { atividades de } \\
\text { desenvolvimento } \\
\text { produtos no país. }\end{array}$ & $\begin{array}{c}\text { P3: As multinacionais estudadas realizam atividades de } \\
\text { desenvolvimento de produtos no Brasil. }\end{array}$ \\
\hline $\begin{array}{l}\text { Identificar atividades de desenvolvimento } \\
\text { de produtos realizadas em suas unidades } \\
\text { produtivas estrangeiras. }\end{array}$ & $\begin{array}{c}\text { P4: A empresa multinacional internacionaliza seu } \\
\text { desenvolvimento de produtos, dispersando suas unidades de } \\
\text { P\&D globalmente }\end{array}$ \\
\hline
\end{tabular}




\section{III - ASPECTOS METODOLÓGICOS}

Etimologicamente, metodologia é o estudo dos métodos, dos caminhos usados para se realizar uma pesquisa científica. Método representa um procedimento racional e ordenado, constituído por instrumentos básicos, o que implica utilizar a reflexão e a experimentação para alcançar os objetivos pré-estabelecidos no planejamento de uma pesquisa (TEIXEIRA, 2005). Ao se planejar uma pesquisa científica, faz-se necessário analisar seus objetivos para, com isso, determinar o método mais apropriado para alcançá-los.

Esta pesquisa exigiu que, primeiramente, se entendesse como as multinacionais compreendem o desenvolvimento de produto integrado à estratégia de globalização proposta por elas. Ou seja, é necessário analisar como os dois eixos estratégicos das multinacionais interagem: o da inovação e o da globalização da produção. Essa integração é importante, porque identifica a seriedade com que a alta administração da empresa atribui ao desenvolvimento de produtos e seu planejamento global. Com isso em mente, serão analisadas a estrutura da função P\&D, suas instalações, como as atividades de desenvolvimento são conduzidas pela empresa no Brasil e, por fim, como elas são conduzidas no exterior.

\subsection{TIPO DE PESQUISA}

A pesquisa realizada apresentou natureza exploratória e qualitativa. Exploratória, porque se propôs a compreender o problema enfrentado pelo pesquisador, procurando explorar a situação para prover critérios e um melhor entendimento (MALHOTRA, 2001). Qualitativa, pois permitiu o entendimento do fenômeno, segundo a perspectiva dos 
participantes da situação estudada, propiciando uma interpretação própria do pesquisador (NEVES, 1996).

O método de pesquisa selecionado foi o estudo de caso, mais adequado quando se enfrenta questões do tipo "como" e "por que", com pouco controle sobre os acontecimentos, e com o foco centrado em fenômenos contemporâneos, inseridos em algum contexto da vida real (YIN, 2005). De acordo com Meyer (2001), o estudo de caso é uma investigação detalhada de uma ou mais organizações, ou de um grupo de organizações, com o intuito de fornecer uma análise do contexto e dos processos do fenômeno pesquisado. Yin (2005) acrescenta que o estudo de caso é uma estratégia de pesquisa, responsável por investigar um fenômeno contemporâneo dentro de seu contexto da vida real, especialmente quando os limites entre o fenômeno e o contexto não estão claramente definidos. Já para Martins (2006a), o estudo de caso é uma estratégia que realiza uma investigação empírica sobre fenômenos dentro de seu contexto real, onde o pesquisador não tem controle sobre os eventos ou as variáveis. Neste caso, o pesquisador busca apreender a situação sob estudo e, criativamente, descrever, compreender e interpretar a complexidade de um caso concreto. Esse tipo de estudo possibilita a penetração na realidade social, não conseguida plenamente pela avaliação quantitativa (MARTINS, 2006a).

Neste trabalho, seguindo a linha de Yin (2005) e Martins (2006a), os estudos de caso foram tratados como uma estratégia de pesquisa. É importante ressaltar ainda que a pesquisa foi um estudo de casos múltiplos. Yin (2005) considera que estudos de caso único e múltiplo são variantes de uma mesma estrutura metodológica. Porém, um ponto importante dentro do estudo de casos múltiplos, é a lógica da replicação e não da amostragem. Assim, cada caso, ao ser analisado, deve ser visto como um estudo diferente, e não como parte de um grupo, como na lógica da amostragem (YIN, 2005). 


\subsection{COLETA DE DADOS: MÉTODO E INSTRUMENTO}

\subsubsection{Tipos de dados}

Os dados coletados neste trabalho foram primários e secundários. Para analisar a internacionalização nas atividades de $\mathrm{P} \& \mathrm{D}$ interno das multinacionais, este trabalho obteve os dados primários por meio de entrevistas com representantes das empresas. Como fontes secundárias de dados, foram utilizados: notícias, artigos científicos, e sites das empresas pesquisadas, ou seja, materiais que forneceram dados sobre o processo de internacionalização das multinacionais. Além destes, em caso de anuência da empresa, foram coletados documentos ou dados pertencentes à organização: relatórios, contratos, planejamentos, indicadores, entre outros.

Para a coleta de dados, foram utilizadas as técnicas de entrevista em profundidade e de análise documental. A entrevista em profundidade é uma técnica de coleta com objetivo é entender e compreender o significado que os entrevistados atribuem a questões e situações. Denomina-se em profundidade, uma entrevista não estruturada, em que o respondente é abordado para obtenção de informações detalhadas sobre um tema específico, com a finalidade de levantar as motivações, crenças, percepções e atitudes em relação ao objeto sob investigação (MARTINS, 2006a). Esse instrumento foi utilizado para levantar as percepções dos respondentes a respeito do processo de internacionalização e do gerenciamento do P\&D.

Além das entrevistas, foram coletados documentos relacionados ao processo de internacionalização e à função $\mathrm{P} \& \mathrm{D}$. A pesquisa documental se assemelha à pesquisa bibliográfica, todavia a busca se concentra em material não editado como cartas, memorandos, planejamentos, propostas, relatórios, estudos, avaliações, contratos, entre outros. A utilização desses documentos propiciou uma compreensão objetiva das estratégias 
adotadas pela empresa à época da tomada de decisão, seus resultados e se os objetivos pretendidos foram alcançados. A partir da confrontação entre as percepções dos respondentes sobre a internacionalização e os fatos documentados, o trabalho procurou pontos de suporte ou contradição. Este método de análise é definido por Martins (2006a) como triangulação de dados. Com isso, obteve-se ter um panorama da internacionalização do desenvolvimento de produtos, do seu planejamento, e da sua execução. Um resumo sobre as empresas, com os dados pertinentes à pesquisa, está contido no apêndice desse trabalho.

Um ponto importante a ser salientado, é que, apesar de ter sido utilizado o mesmo protocolo de coleta de dados sobre as empresas para todos os entrevistados, a quantidade e qualidade dos dados foram diferentes, devido às características pessoais de cada um deles.

\subsubsection{Unidade de análise e perfil dos entrevistados}

Neste estudo, a unidade de análise escolhida foi a internacionalização da função P\&D em empresas multinacionais brasileiras. Seis empresas responderam ao convite para a realização da pesquisa: Embraco, Gerdau, Marcopolo, Smar, Tigre, WEG. No caso da Marcopolo, é importante ressaltar que não houve visita e entrevista. Ao invés disso, por opção e solicitação da empresa, foi enviado por e-mail, o roteiro de entrevista, transformado em questionário, foi enviado por e-mail, e respondido por seu gerente de P\&D. Além desse questionário, o pesquisador compareceu a palestras sobre a internacionalização da empresa, ministradas por um dos diretores, onde teve a oportunidade de conversar com ele sobre o tema.

Como as proposições do estudo abordam tanto o nível estratégico quanto o nível tático da função $P \& D$, foram entrevistados diretores e gerentes dessa função nas empresas. Nas que dispunham de um diretor responsável pela atuação internacional da firma, eles também foram 
entrevistados, quandp necessário, para a obtenção de um panorama mais geral do processo de internacionalização.

$\mathrm{Na}$ Embraco, foram entrevistados quatro funcionários, o gerente de recursos de engenharia corporativo, o chefe de relações institucionais para o $\mathrm{P} \& \mathrm{D}$, um engenheiro corporativo sênior e a bibliotecária responsável pelo controle da propriedade intelectual da empresa. Na WEG, foram entrevistados, além do gerente do departamento de P\&D do produto, o gerente de engenharia de motores industriais, o gerente do departamento de engenharia de produto, e o chefe de seção de tecnologia de produto. Na Gerdau, foram entrevistados o coordenador do Gerdau Business System, o gerente de tecnologia em aços especiais, e o consultor técnico P\&D. Na Smar, os contatos foram com o diretor de desenvolvimento, e com um dos gerentes de desenvolvimento. Na Tigre, foram entrevistados o gerente de pesquisa e desenvolvimento e o chefe de seção de tecnologia de produto. $\mathrm{Na}$ Marcopolo, o questionário foi respondido pelo gerente da engenharia de desenvolvimento.

As entrevistas foram realizadas entre outubro de 2006 e março de 2007 e forneceram os resultados que estão apresentados no capítulo quatro desta dissertação. Na próxima seção está o protocolo de estudo de caso utilizado nas entrevistas.

\subsection{PROTOCOLO DO ESTUDO DE CASO}

Este protocolo constitui um conjunto de códigos, menções e procedimentos suficientes para se replicar o estudo, ou aplicá-lo em outro caso. Isso dá condição prática para testar a confiabilidade do estudo, pois oferece a segurança de que o trabalho foi planejado, e que seus resultados possibilitaram explicações sobre a realidade investigada (MARTINS, 2006a).

O referencial bibliográfico do trabalho forneceu o suporte teórico para o estudo de caso conduzido nas empresas multinacionais. A partir deste referencial, foram construídas as 
proposições e foi preparado o protocolo do estudo de caso. A primeira parte do protocolo foi apresentada na seção 2.6, quando foram vinculados os objetivos da pesquisa com as proposições levantadas no referencial.

O passo seguinte para a confecção do protocolo de pesquisa foi a montagem do roteiro de entrevistas, utilizado junto às empresas. Para isso, foram analisadas as proposições levantadas no referencial teórico e formuladas as perguntas incluídas no roteiro de entrevista.

\subsubsection{Roteiro de entrevista}

A proposição $\boldsymbol{P 1}$ verifica se a internacionalização do processo produtivo levou a empresa a internacionalizar sua atividade de desenvolvimento de produtos. Assim, as questões feitas foram:

- O que levou a empresa a internacionalizar suas operações produtivas?

- Quando começou a internacionalização das operações produtivas?

- Para quais países a internacionalização foi feita?

- Qual o motivo da escolha desses países?

- Aconteceram casos de desinvestimento em algum país? Por que isso ocorreu?

A proposição $\boldsymbol{P 2}$ procura uma consonância entre a estratégia global da empresa e a estratégia específica de P\&D. Para avaliar essa conformidade, foram usadas as respostas dadas às questões anteriores, junto com as respostas às seguintes perguntas:

- Como está estruturada a função P\&D na empresa?

- A empresa possui algum centro de pesquisa?

- Onde estão localizadas as instalações de P\&D da empresa?

- Em caso de mais de uma instalação, como se dá a coordenação das atividades?

- Como se dão o planejamento e a gestão para a função P\&D? 
- Quantas pessoas trabalham na função P\&D no Brasil?

- Qual a formação educacional do pessoal?

- Na opinião do entrevistado, qual a relevância do P\&D para empresa?

- Baseado na resposta anterior, como o entrevistado descreveria a estratégia de P\&D?

- Quais as atividades de P\&D realizadas pela empresa?

- Além das atividades produtivas, a empresa internacionalizou alguma atividade relacionada à função $\mathrm{P} \& \mathrm{D}$ (pesquisa básica, pesquisa aplicada, desenvolvimento de produtos, serviços de assistência técnica)?

- Em caso afirmativo, quais motivos levaram a empresa descentralizar esta atividade de $\mathrm{P} \& \mathrm{D} ?$

- Em caso negativo, quais motivos levam a empresa a não internacionalizar seu P\&D?

A proposição $\boldsymbol{P 3}$ procura detalhar o desenvolvimento de produtos realizado pela empresa no Brasil. A importância deste ponto está no esclarecimento das atividades realizadas no país para uma confrontação com as atividades realizadas no exterior.

- Como está estruturado administrativamente o desenvolvimento de produtos na empresa?

- Como o entrevistado descreveria o processo de desenvolvimento de produtos na empresa (planejamento, organização, gestão, coordenação)?

- Quantas pessoas trabalham na área de desenvolvimento de produtos no Brasil?

- Qual é a formação educacional do pessoal?

- Quais as atividades de desenvolvimento de produtos realizadas no Brasil?

- Onde são realizados os testes e ensaios necessários para o desenvolvimento de produtos?

- Alguma parcela do orçamento é destinada ao desenvolvimento de produtos nas subsidiárias do exterior? 
- A empresa possui alguma parceria com empresas no exterior, para o desenvolvimento de produtos?

A proposição $\boldsymbol{P 4}$ analisa a internacionalização da atividade de desenvolvimento de produtos da empresa. As questões pertinentes seriam:

- A empresa, em algum momento, internacionalizou alguma atividade relacionada com o desenvolvimento de produtos?

- Como foi essa experiência (obteve êxito ou não)?

- O que levou a empresa a internacionalizar seu desenvolvimento de produtos?

- Em caso negativo, quais fatores levaram a empresa a optar por permanecer com seu desenvolvimento de produtos centralizado na matriz?

- Já foi realizado algum projeto de integração internacional de desenvolvimento de produtos? Como ele foi gerenciado?

- Em quais países a empresa descentralizou suas atividades de desenvolvimento de produtos? Quais fatores levaram a escolha desses países?

- Algum desenvolvimento de produtos foi realizado, formalmente, nas fábricas do exterior? E informalmente?

- A empresa utiliza estruturas diferentes para gerenciar as atividades de pesquisa das de desenvolvimento?

- Quais são os métodos de proteção de conhecimento utilizados pela empresa?

- Esses métodos são empregados nas subsidiárias no exterior? De qual forma?

No quadro 3.1, a seguir, estão as proposições criadas para este trabalho, bem como as questões pertinentes. 


\begin{tabular}{|c|c|}
\hline Proposições & Questões de pesquisa \\
\hline $\begin{array}{l}\text { P1: As MNB, após } \\
\text { internacionalizarem seus processos } \\
\text { produtivos, internacionalizam seu } \\
\text { desenvolvimento de produtos. }\end{array}$ & $\begin{array}{l}\text { O que levou a empresa a internacionalizar suas operações produtivas? } \\
\text { Quando começou a internacionalização das atividades produtivas? } \\
\text { Para quais países a internacionalização foi feita? } \\
\text { Qual o motivo da escolha desses países? } \\
\text { Aconteceram casos de desinvestimento em algum país? Por que isso ocorreu? }\end{array}$ \\
\hline $\begin{array}{l}\text { P2: Nas multinacionais brasileiras } \\
\text { estudadas há uma consonância entre } \\
\text { a estratégia global da empresa e sua } \\
\quad \text { estratégia de } P \& D .\end{array}$ & $\begin{array}{l}\text { Como está estruturada a função P\&D na empresa? } \\
\text { A empresa possui algum centro de pesquisa? } \\
\text { Onde estão localizadas as instalações de P\&D da empresa? } \\
\text { Em caso de mais de uma instalação, como se dá a coordenação das atividades? } \\
\text { Como se dão o planejamento e a gestão para a função P\&D? } \\
\text { Quantas pessoas trabalham na função P\&D no Brasil? } \\
\text { Qual a formação educacional do pessoal? Quantos têm nível técnico, terceiro grau } \\
\text { completo ou alguma pós-graduação? } \\
\text { Na opinião do entrevistado, qual a relevância do P\&D para empresa? } \\
\text { Baseado na resposta anterior, como o entrevistado descreveria a estratégia de P\&D? } \\
\text { Quais as atividades de P\&D realizadas pela empresa? } \\
\text { Além das atividades produtivas, a empresa internacionalizou alguma atividade relacionada } \\
\text { à função P\&D (pesquisa básica, pesquisa aplicada, desenvolvimento de produtos, serviços } \\
\text { de assistência técnica)? } \\
\text { Em caso afirmativo, quais fatores levaram a empresa considerar descentralizar esta } \\
\text { atividade de P\&D? } \\
\text { Em caso negativo, quais motivos levam a empresa a não internacionalizar seu P\&D? }\end{array}$ \\
\hline $\begin{array}{l}\text { P3: As multinacionais estudadas } \\
\text { realizam atividades de } \\
\text { desenvolvimento de produto no } \\
\text { Brasil. }\end{array}$ & $\begin{array}{l}\text { Como está estruturado administrativamente o desenvolvimento de produtos na empresa? } \\
\text { Como o entrevistado descreveria o processo de desenvolvimento de produtos na empresa } \\
\text { (planejamento, organização, gestão, coordenação)? } \\
\text { Quantas pessoas trabalham na área de desenvolvimento de produtos no Brasil? } \\
\text { Qual é a formação do pessoal? } \\
\text { Quais as atividades (testes e ensaios, prototipagem, pesquisa de mercado etc.) de } \\
\text { desenvolvimento de produtos realizadas no Brasil? } \\
\text { Onde são realizados os testes e ensaios necessários para o desenvolvimento de produtos? } \\
\text { Alguma parcela do orçamento é destinada ao desenvolvimento de produtos nas subsidiárias } \\
\text { do exterior? } \\
\text { A empresa possui alguma parceria com empresas no exterior, para o desenvolvimento de } \\
\text { produtos? }\end{array}$ \\
\hline $\begin{array}{l}\text { P4: A empresa multinacional } \\
\text { internacionaliza seu desenvolvimento } \\
\text { de produto, dispersando suas } \\
\text { unidades de } P \& D \text { globalmente. }\end{array}$ & $\begin{array}{l}\text { A empresa, em algum momento, internacionalizou alguma atividade relacionada com o } \\
\text { desenvolvimento de produtos (testes e ensaios, prototipagem, pesquisa de mercado etc.)? } \\
\text { Como foi essa experiência (obteve êxito ou não)? } \\
\text { O que levou a empresa a internacionalizar seu desenvolvimento de produtos? } \\
\text { Em caso negativo, quais fatores levaram a empresa a optar por permanecer com seu } \\
\text { desenvolvimento de produtos centralizado na matriz? } \\
\text { Já foi realizado algum projeto de integração internacional de desenvolvimento de produtos? } \\
\text { Como ele foi gerenciado? } \\
\text { Em quais países a empresa descentralizou suas atividades de desenvolvimento de produtos? } \\
\text { Quais fatores levaram a escolha desses países? } \\
\text { Algum desenvolvimento de produtos foi realizado, formalmente, nas fábricas do exterior? } \\
\text { E informalmente? } \\
\text { A empresa utiliza estruturas diferentes para gerenciar as atividades de pesquisa das de } \\
\text { desenvolvimento? } \\
\text { Quais são os métodos de proteção de conhecimento utilizados pela empresa? } \\
\text { Esses métodos são empregados nas subsidiárias no exterior? De qual forma? }\end{array}$ \\
\hline
\end{tabular}

Quadro 3.1 - As proposições e as questões pertinentes do roteiro de entrevistas 


\subsubsection{Dicionário de termos}

O último passo do protocolo de estudo de caso foi a criação de um dicionário de termos. Esse dicionário serve como um balizador entre o entrevistado e o entrevistador e, além disso, auxilia famializar o leitor do trabalho com os termos utilizados na pesquisa, criando uma linguagem comum para a replicação do estudo.

- Atividades de P\&D: pesquisa básica, pesquisa aplicada, desenvolvimento de produtos/processos, serviços de assistência-técnica.

- Atividades de desenvolvimento de produto: Atividades ligadas ao desenvolvimento do produto como pesquisa de mercado, prototipagem, testes e ensaios.

- Desinvestimento: Retirada do investimento. Fechamento de fábrica no exterior.

- Formação educacional: Nível de escolaridade dos colaboradores. Dentre: primeiro grau, segundo grau, técnico, terceiro grau, pós-graduação.

- Métodos de proteção de conhecimento: Patentes, segredo industrial, marcas etc.

- Processo de desenvolvimento de produto: Pesquisa de mercado, pesquisa, desenvolvimento, prototipagem, venda e pós-venda.

- Relevância do P\&D: Os pontos que o entrevistado considerar importantes do P\&D para a criação de vantagens competitivas da empresa. Os pontos levantados podem levantar questionamentos sobre o P\&D e sua internacionalização.

\subsection{AS EMPRESAS ESTUDADAS}

Esta última seção precede a apresentação dos resultados da pesquisa, e foi usada para introduzir, brevemente, as empresas estudadas. Maiores informções estão contidas no apêndice A. Porém, antes de começar essa descrição, alguns pontos precisam ser levantados. 
O primeiro é referente à nacionalidade da Embraco. Em 1997, a americana Whirpool assumiu o controle acionário da empresa, assim deixando de ser uma "multinacional brasileira". A partir de abril de 2006 houve uma reestruturação e a empresa passou a ser uma unidade de negócios da Whirpool Brasil. Contudo, a matriz da unidade de negócio continua sediada no Brasil, de forma que todas as decisões são tomadas no país. Outro ponto é sobre o P\&D e a internacionalização da empresa. Sua história, desde o início, demonstra um sério compromisso com a pesquisa e o desenvolvimento e, além disso, ela iniciou seu processo de internacionalização em 1994, ou seja, antes de ser adquirida. Ao mesmo tempo, na pesquisa realizada pelo BCG (BCG, 2006), ela é considerada como uma empresa brasileira e o próprio site da empresa alega que "dada a peculiaridade de seu negócio, continua a operar de forma estruturalmente independente da Whirpool" (EMBRACO, 2006). Um último ponto é que apesar da GERDAU possuir cerca de 40 unidades no exterior, o P\&D é gerenciado centralizadamente na usina de Charqueadas (RS). Contudo, em 2006, com a aquisição da Sidenor, a empresa incorporou seu primeiro e único departamento de P\&D no exterior.

A Embraco foi fundada em 1971, em Joinville (SC), onde, atualmente, mantém uma unidade fabril, a administração, o centro de pesquisa e desenvolvimento, a Fundição Embraco, e a EECON - Embraco Electronics Controls - que desenvolve, fabrica e comercializa sistemas eletrônicos para eletrodomésticos. Em Itaiópolis (SC), a empresa possui outra fábrica, dedicada à produção de componentes elétricos e trocadores de calor, utilizados em unidade de condensadores e seladas. Os produtos da empresa são: compressores, componentes de ferro fundido, componentes elétricos, condensadores e evaporados. Sua participação de mercado é de $20 \%$ em relação a vendas e emprega cerca de dez mil pessoas (EMBRACO, 2006).

A Gerdau iniciou suas operações em 1902, com a Fábrica de Pregos Ponta de Paris, na cidade de Porto Alegre, Rio Grande do Sul. Em 1948, a empresa entra para o setor 
siderúrgico, com a instalação da Usina Riograndense e, em 1968, inicia a produção em Pernambuco, com a Açonorte. Hoje, a empresa tem como principal produto os vergalhões para a construção civil. Em 2004, seu faturamento total chegou a R\$ 23,4 bilhões, um aumento de $48 \%$ em relação ao ano anterior. Ainda em 2004, a empresa possuía 20160 funcionários, alocados geograficamente da seguinte forma: $71 \%$ no Brasil, $25 \%$ EUA e Canadá e 4\% entre Argentina, Chile e Uruguai (ALTMANN, 2005). O grupo Gerdau possui usinas siderúrgicas distribuídas no Brasil, Argentina, Canadá, Chile, Colômbia, Estados Unidos e Uruguai. Hoje, alcança uma capacidade instalada total de 19 milhões de toneladas de aço por ano (GERDAU, 2001).

A Marcopolo tem sua matriz instalada na cidade de Caxias do Sul, RS. Fundada em 1949 como Nicola e Cia Ltda, a Marcopolo atualmente é, em participação de mercado, a maior encarroçadeira de ônibus no Brasil. A empresa possui 10590 colaboradores, sendo 8151 no Brasil e 2439 no exterior (MARTINS, 2006b). Sua capacidade de produção no Brasil é de 70 unidades por dia, enquanto que a do grupo todo é de 110 unidades por dia. A produção do ano passado, até outubro, foi de 23463 unidades. A participação mundial de mercado da Marcopolo era de 6,5\% em 2005, patamar que permaneceu inalterado em 2006 (MARTINS, 2005; MARTINS, 2006b).

A Smar Equipamentos Industriais Ltda. é uma das líderes mundiais em tecnologia de automação industrial, com filiais em sete países. Na década de 80, a empresa iniciou operações voltadas para os setores de mineração, químico, de bebidas, alimentos, petróleo e outros. Atualmente, está transferindo a sua tecnologia de medição usada em grandes empreendimentos industriais, para prédios de apartamentos e escritórios, shoppings, hospitais e condomínios residenciais (GAZETA MERCANTIL, 1999). A empresa compete diretamente com as grandes empresas de automação industrial e tecnologia de ponta do mundo, ficando em segundo lugar, no ranking mundial de empresas do ramo (MAUAD; MARTINELLI; 
LIBONI, 2006) e mantém dois laboratórios de pesquisa, em Houston e Nova York, nos Estados Unidos.

A Tigre iniciou suas operações, na cidade de Joinville, em 1941, como uma fábrica de pentes e cachimbos feitos a partir de chifres de boi. Alguns anos depois, com a disseminação do plástico, a empresa começou a utilizar essa nova matéria-prima na fabricação de produtos como pentes, piteiras, copos, pratos, brinquedos e leques. No fim dos anos 50, resolveu investir em um novo projeto, usando o PVC para fabricar tubos e conexões para instalações hidráulicas (TIGRE, 2005).

Fundada em 1961, em Jaraguá do Sul, SC. A WEG produziu inicialmente motores elétricos, começou a expandir suas atividades a partir da década de 80, com a fabricação de geradores, componentes eletroeletrônicos, produtos para automação industrial, transformadores de força e distribuição, tintas líquidas e em pó, e vernizes eletroisolantes. Hoje a WEG é uma das maiores fabricantes de motores elétricos da América Latina, está presente em mais de 100 países, possuindo três unidades fabris na Argentina, duas no México, uma em Portugal e uma na China. (WEG, 2006). 


\section{IV - ANÁLISE E DISCUSSÃO DOS RESULTADOS}

Este capítulo está dividido em duas partes: a primeira trata da apresentação dos resultados obtidos em cada um dos seis casos, e a segunda, da discussão dos casos frente às teorias apresentadas no referencial teórico. A divisão foi feita com o intuito de apresentar os dados obtidos das empresas sem perder a linearidade de cada caso. Na matriz abaixo (Quadro 4.1), está demonstrado o esquema de apresentação e discussão dos dados.

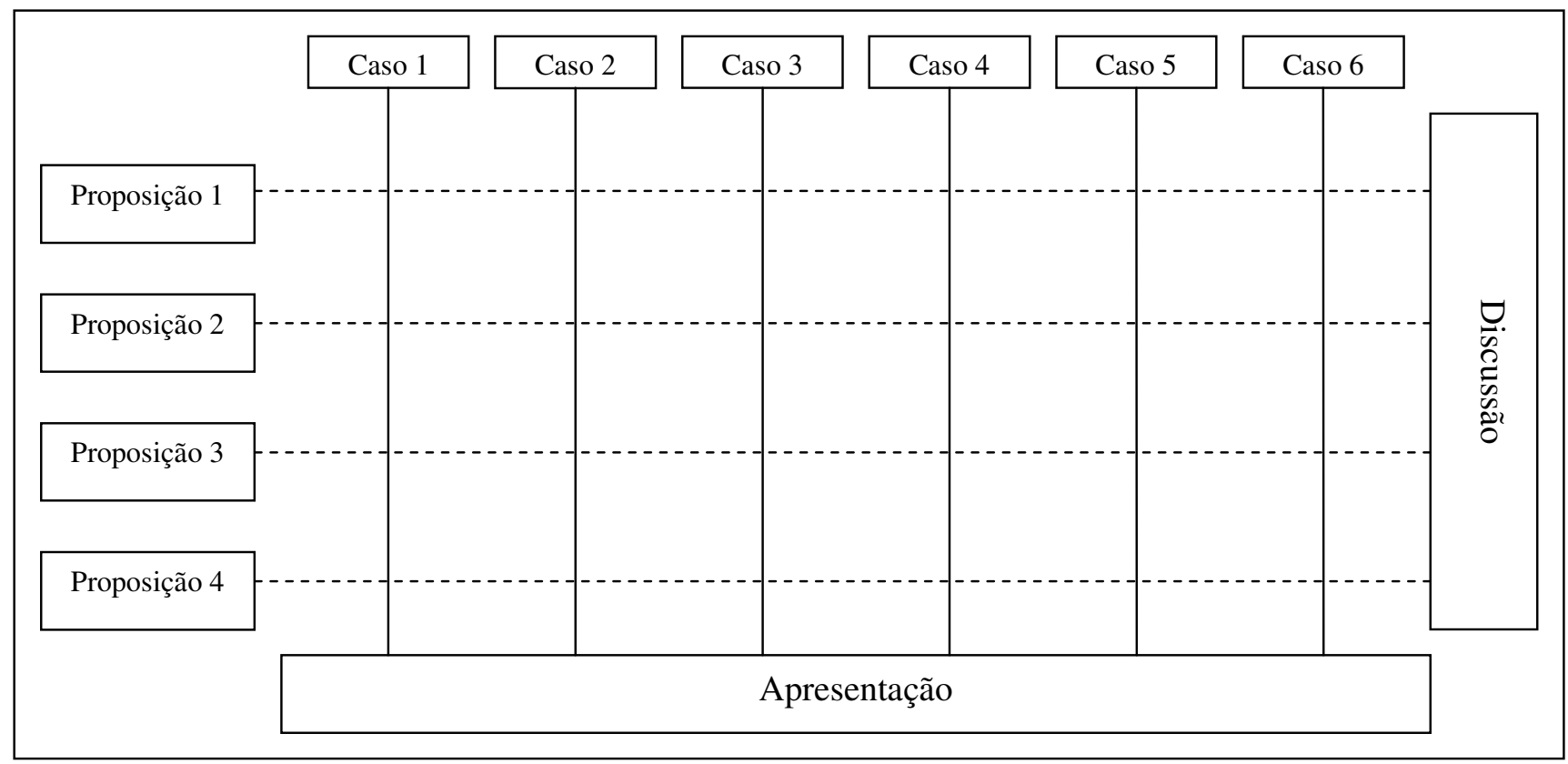

Quadro 4.1 - Esquema de apresentação e discussão dos dados.

\subsection{APRESENTAÇÃO DOS DADOS}

Nesta seção, serão apresentados os seis casos. Os dados de cinco desses casos foram levantados a partir de entrevistas e visitas às empresas. Em um caso - o da MARCOPOLO -, foi remetido o questionário sobre a internacionalização do $\mathrm{P} \& \mathrm{D}$ e foram assistidas palestras sobre a internacionalização da empresa, onde o pesquisador teve oportunidade de conversar com um dos diretores sobre o assunto. A apresentação dos resultados está dividida por 
empresa, e cada uma delas de acordo com a ordem das quatro proposições de estudo de caso utilizadas.

\subsubsection{WEG}

\subsubsection{Internacionalização}

A WEG começou a se expandir internacionalmente no início dos anos setenta, primeiramente por meio de representantes e, depois, com a abertura de escritórios próprios, um nos EUA e outro na Bélgica. Segundo os entrevistados, o processo de internacionalização da empresa é irreversível, tanto no nível comercial quanto no fabril. Já com um grande mercado interno, a direção optou pela estratégia de internacionalização, para dar continuidade a seu desenvolvimento. Outra razão foram os custos logísticos de atendimento de clientes no exterior. Com a internacionalização, a WEG começou a atender um mercado mais exigente, o que a forçou a desenvolver produtos mais competitivos e adequados às necessidades dos seus novos clientes.

De acordo com os entrevistados, o processo de internacionalização da empresa pode ser descrito em três estágios. O primeiro, relativo a uma fase anterior à internacionalização, foi quando a empresa assegurou uma posição no mercado interno, e percebeu que para continuar crescendo, seria necessário procurar mercados no exterior. Deu início então ao segundo estágio, atuando no exterior por meio de revendedores e, em seguida, implantando escritórios próprios para comercialização. O terceiro, e atual, estágio deu-se com a implantação de fábricas no exterior, iniciado no ano de 2000. De acordo com os entrevistados, a compra de uma fábrica, mesmo tecnologicamente ultrapassada, implica a aquisição de toda 
uma estrutura. Assim, a estratégia da empresa para a entrada no exterior é a aquisição de fábricas já existentes, para uma posterior expansão.

Um aspecto interessante foi que, de início, nenhum das empresas do setor percebeu a WEG como concorrente importante no mercado. Ela se aproveitou disso para firmar contratos de transferência de tecnologia com um concorrente do exterior, procurando obter, além dos projetos, o conhecimento. Atualmente, os principais concorrentes internacionais já não comercializam mais sua tecnologia com a empresa.

De acordo com os entrevistados, as plantas no exterior foram adquiridas para atender às demandas dos mercados locais. As fábricas são habilitadas a produzir toda a linha de produtos, porém cada uma delas atende apenas seu mercado local. Elas devem atuar de forma competitiva, principalmente na região onde estão localizadas. Além disso, com a compra da fábrica em Portugal, a empresa adquiriu uma nova linha de produtos e novas competências que puderam ser internalizadas. Um último aspecto interessante é que, de acordo com os entrevistados, a empresa tem o interesse de se integrar à comunidade onde atua. Assim, "a WEG não é uma empresa brasileira implantada na Argentina, mas uma empresa Argentina também”. De acordo com os entrevistados, essa é uma diferença importante na filosofia de internacionalização da empresa - a de procurar se ajustar à cultura do país - e pouco a pouco integrar as duas culturas. Dessa forma, seu pessoal do Brasil é enviado para trabalhar no exterior, da mesma forma que o do exterior vem para o Brasil, mesclando times de trabalho, entendendo a cultura local e, paulatinamente, transmitindo a cultura da empresa. Isso é feito em todos os níveis hierárquicos, inclusive no nível gerencial, trazendo funcionários do exterior para administrar departamentos da matriz. Esse intercâmbio de colaboradores facilita a interface entre matriz e subsidiárias, criando vínculos entre os funcionários das diferentes plantas. 


\subsubsection{P\&D}

No início, por não possuir ainda tecnologia própria, a empresa procurou adquiri-la por meio de parcerias com uma concorrente européia. Essa cooperação foi importante para fornecer à empresa uma tecnologia de fundo e para o desenvolvimento de produtos durando até 1993. A partir daí, a empresa começou a desenvolver sua tecnologia utilizando a colaboração de consultores e de universidades no Brasil e no exterior.

Atualmente, de acordo com os entrevistados, a gestão da tecnologia da empresa está baseada em três pilares: adaptação tecnológica, contratação externa e desenvolvimento próprio. A adaptação de tecnologia refere-se tanto ao benchmarking realizado em produtos de concorrentes, em que se avalia o grau de inovação tecnológica, quanto ao acompanhamento das tendências tecnológicas junto a fornecedores, consultores, clientes e principais revendedores. A contratação externa de tecnologia são acordos realizados com empresas para a compra de pacotes abertos. Esses pacotes englobam tanto a tecnologia de produto e processo, quanto o treinamento de seus colaboradores, para que esse conhecimento seja incorporado ao quadro de competências tecnológicas. O terceiro pilar está relacionado ao desenvolvimento próprio. A empresa utiliza seu próprio $\mathrm{P} \& \mathrm{D}$ e engenharia, cooperações com universidades e contratação de consultores externos para aprimorar sua tecnologia em produto e processos.

Portanto, a política de $\mathrm{P} \& \mathrm{D}$ da empresa é gerar tecnologia e conhecimento próprios para, com isso, desenvolver produtos e processos inovadores, internalizando o conhecimento e a tecnologia no quadro de competências da empresa. A empresa considera imprescindível desenvolver tecnologia própria, porém optou por não investir em pesquisa básica. Ao invés disso, para crescer, investe em pesquisa aplicada e desenvolvimento, o que "mantém a empresa viva e competitiva", segundo os entrevistados. 
O departamento de P\&D desempenha três atividades principais: o desenvolvimento de novos materiais (especialmente com fornecedores); a otimização e aperfeiçoamento dos produtos atuais; e o desenvolvimento de novas tecnologias. Além dessas atividades, o departamento também presta trabalhos assessoria técnica aos outros departamentos da empresa.

\subsubsection{Desenvolvimento de produtos}

Todo projeto novo começa pelo $\mathrm{P} \& \mathrm{D}$, como uma concepção. Concluída essa concepção, o projeto é passado para a engenharia, onde é detalhado. A demanda de novos projetos pode advir de solicitações de clientes ou de informações sobre os concorrentes. Além disso, o próprio $\mathrm{P} \& \mathrm{D}$ pode oferecer aos clientes algo que tenha desenvolvido recentemente. Assim, o P\&D é responsável pelo desenvolvimento do conceito ou da tecnologia, pelo modelo matemático e físico, e pelo teste de avaliação de funcionamento. Nas palavras de um dos entrevistados: "O P\&D é responsável por desenvolver o produto com uma concepção diferente ou de tipo de funcionamento diferente, e fazer com que o projeto funcione bem". Em contrapartida, a engenharia é responsável por desenvolver o produto para sua comercialização e adequação das linhas de produção. É importante ressaltar, portanto, que dentro da função de engenharia da empresa, há também uma seção de desenvolvimento. Esse setor está interligado às áreas de vendas e de $\mathrm{P} \& \mathrm{D}$, e é responsável pela análise da interação entre o mercado e a tecnologia. Segundo os entrevistados, essa área "sombreada" entre as atividades de P\&D e engenharia não gera conflitos.

Além disso, quando a empresa precisa fazer um novo desenvolvimento que não consta entre suas competências, contrata consultores estrangeiros, geralmente engenheiros aposentados de grandes multinacionais que vêm ao Brasil especialmente para essa finalidade. 
Essa contratação de consultores estrangeiros confere mais confiança ao projeto, segundo os entrevistados.

\subsubsection{Internacionalização do desenvolvimento de produto}

De acordo com os entrevistados, a estratégia da empresa é centralizar no Brasil, tanto a pesquisa quanto o desenvolvimento. Assim, as subsidiárias não fazem desenvolvimento de produtos, mas possuem a liberdade de customizar os produtos para os mercados nos quais atuam. Contudo, a WEG mantém atividades de desenvolvimento em sua unidade portuguesa, que atualmente produz uma linha especial de produtos, de maior valor agregado, projetados para atuar em áreas de risco de explosão. Um ponto importante é que a empresa não detinha antes a competência de fabricar esse tipo de produto, e trouxe esse conhecimento para o Brasil. O desenvolvimento dessa linha de produtos permaneceu internacionalizada, pois, para que os produtos sejam comercializados na Europa, precisam ter a certificação de laboratórios da região. Ao invés de desenvolver aqui no Brasil e enviar para ser certificado na Europa, a subsidiária fica responsável pela produção e posterior certificação. A WEG planeja ampliar essa linha da subsidiária européia, agregando produtos com projeto básico brasileiro e adaptando-os à prova de explosão.

A unidade européia sempre teve uma área de $\mathrm{P} \& \mathrm{D}$, mas atualmente, qualquer desenvolvimento novo passa, obrigatoriamente, pelo Brasil. No entanto, a subsidiária tem liberdade para contratar consultores e fazer seus desenvolvimentos de produtos.

Segundo os entrevistados, as subsidiárias no exterior devem funcionar como extensão do que existe na matriz, porém a WEG não quer criar uma estrutura pesada em cada uma das unidades. Assim, ela concentra algumas atividades no Brasil com o intuito de proporcionar uma maior flexibilidade para as subsidiárias. Por fim, como todas as plantas possuem 
engenharia e produção internacionalizadas, e os colaboradores dessas áreas nas subsidiárias começam a participar das decisões tomadas na matriz, comparecendo a reuniões e integrando comissões até mesmo de forma virtual. Com isso, eles podem opinar sobre os produtos, alterar ou criar novas linhas. Porém, apesar desse canal de comunicação aberto entre a matriz e as subsidiárias, não há um canal formal de comunicação entre as subsidiárias.

\subsubsection{EMBRACO}

\subsubsection{Internacionalização}

A Embraco possui três plantas produtivas no exterior: duas na Europa (uma na Itália e outra na Eslováquia), e uma na Ásia (China). Os fatores que motivaram a internacionalização da produção da empresa foram a proximidade com o cliente estrangeiro, questões logísticas, a busca de fornecedores alternativos, e a redução de custos. Segundo os entrevistados, não houve nenhuma motivação tecnológica para a internacionalização da produção, mas apenas vantagens logísticas e de localização, que procuravam reduzir o lead-time de cada pedido.

De acordo com os entrevistados, a aquisição da unidade na Europa Ocidental foi devida à necessidade de redefinição estratégica de uma outra empresa pertencente ao grupo e antiga controladora da planta. Como a Embraco e a planta em questão manufaturavam os mesmos produtos, ela adquiriu o controle da planta, o que lhe permitiu abrir uma nova linha de produtos e, conseqüentemente, um novo mercado. Um ponto importante é que, atualmente, essa planta está sofrendo um “desinvestimento" gradual, realizado em virtude dos altos custos da produção e trabalhistas. Os entrevistados afirmam que isso definiu uma estratégia conservadora de investimentos na planta e, ao mesmo tempo, acelerou o processo de abertura de uma fábrica no Leste Europeu, onde os custos são mais baixos em comparação com o resto 
da Europa. Assim, foi feita uma busca de fornecedores locais para tecnologias maduras e a empresa optou pela Eslováquia, que apresentava uma grande usina siderúrgica nas imediações do local de construção da planta.

$\mathrm{Na}$ China, a empresa iniciou suas operações por meio de uma joint-venture. Segundo os entrevistados, a motivação da empresa, além das relativas à localização e logísticas, foram as altas taxas de crescimento de mercado apresentadas pela região. Em 2006, as instalações da unidade mudaram para o setor industrial na mesma cidade, e nessa nova fábrica aumentou-se o número de linhas de produção e foram instalados novos laboratórios.

\subsubsection{P\&D}

Para os entrevistados, a área de P\&D é importante para a empresa, pois é a responsável pelo seu crescimento e sobrevivência. Ela fornece as ferramentas necessárias para a empresa atingir aprimoramentos e inovações em produtos e processos responsáveis pelo aumento da qualidade e da produtividade, e ainda pela diminuição dos custos. As atividades de pesquisa e desenvolvimento tecnológico realizadas pela empresa apresentam como objetivos principais, o aprimoramento dos produtos existentes (consumo de energia, nível de ruído, redução de custo, redução de tamanho, normas ambientais) e o desenvolvimento de produtos inovadores.

Em seu início, a Embraco não possuía competências ou tecnologia para desenvolver e manufaturar os compressores. Assim, seu primeiro passo foi firmar um acordo com uma concorrente européia e começar a produzir localmente, de maneira a depender menos da importação. Apesar disso, porém, a empresa continuou a depender da tecnologia estrangeira. A partir da década de 1980, foram firmados acordos de cooperação tecnológica com universidades brasileiras e do exterior, com o objetivo principal de capacitar a empresa a desenvolver suas competências tecnológicas. Essa estratégia resultou não só em um produto 
totalmente desenvolvido com tecnologia nacional, mas também permitiu que ela atingisse, segundo os entrevistados, um patamar de liderança tecnológica no setor. Dessa forma, o P\&D foi decisivo para o crescimento e a posterior internacionalização da empresa. Sob a ótica dos entrevistados, isso ocorreu porque a empresa não se limitou a manufaturar produtos baseados em plataformas adquiridas de concorrentes estrangeiros, mas apostou no desenvolvimento de sua própria tecnologia.

A empresa dividiu sua gestão de P\&D em quatro, sendo, três gestões-fim e uma gestão-meio. As gestões-fim foram separadas de acordo com as atividades de $\mathrm{P} \& \mathrm{D}$ realizadas - duas são responsáveis pelo desenvolvimento das linhas de produtos e processos; enquanto a terceira se responsabiliza pela pesquisa e desenvolvimento tecnológico mais amplo. A gestãomeio, por sua vez, oferece suporte às outras três gestões, centralizando a coordenação do "pool" de recursos ofertados para cada projeto em andamento. Esse "pool" de recursos é constituído pelos funcionários e pelos recursos de hardware e software dos laboratórios e das demais instalações de $\mathrm{P} \& \mathrm{D}$ das plantas do exterior e do Brasil.

Como a gestão-fim responsável pela pesquisa está alocada no Brasil, todas as atividades de pesquisa da empresa ficam centralizadas na matriz. De acordo com os entrevistados, os custos de implantação de novos laboratórios e de pessoal com as competências necessárias são os maiores impedimentos para a internacionalização da pesquisa. Com a finalidade de adquirir conhecimentos específicos em centros de excelência, a empresa firmou contratos de cooperação tecnológica com universidades no Brasil e no exterior, coordenados centralmente pela matriz. O trabalho de coordenação dessas pesquisas é feito por funcionários ligados à matriz, chamados de "corporativos". Essa "rede de conhecimento" teve início em 1981, com a assinatura de um contrato de cooperação tecnológica com a FEI - Faculdade de Engenharia Industrial de São Bernardo/SP e com a Universidade de São Paulo na área de motores elétricos. Atualmente, esses acordos se 
estendem para centros especializados de 11 países além do Brasil, dois dos quais são considerados países emergentes: Rússia e China.

\subsubsection{Desenvolvimento de produto}

O desenvolvimento de produto realizado pela empresa é dividido em duas estruturas, de acordo com o grau de novidade da tecnologia para a empresa: desenvolvimento de novos produtos/tecnologias e o desenvolvimento de produtos/tecnologias dominados.

Quando é o caso de novos produtos ou de uma tecnologia não dominada, o desenvolvimento fica centralizado no Brasil, sob responsabilidade dos corporativos da empresa, essa estratégia visa internalizar essa tecnologia e diminuir os custos do desenvolvimento. Esse desenvolvimento apresenta como fator gerador as demandas do mercado, assim, quando a demanda contempla um campo que a empresa não domina, os corporativos fazem uma varredura nos meios de comunicação, nas feiras, nas universidades e no mercado, buscando descobrir onde o conhecimento está disponível e quem pode oferecer suporte à pesquisa. Depois de desenvolvido, o conhecimento é internalizado na matriz e disperso nas três plantas no exterior, como um conhecimento já dominado. Assim sendo, apesar do desenvolvimento do produto ser centralizado, esses novos produtos são produzidos onde for mais interessante logisticamente.

O segundo tipo, o desenvolvimento de produtos/tecnologia já dominado, será tratado na seção seguinte, pois é o caso de internacionalização do desenvolvimento. 
4.1.2.4 Internacionalização do desenvolvimento de produtos

Quando é o caso de desenvolvimento de conhecimentos e tecnologias já dominadas pela empresa, a subsidiária do exterior recebe a autonomia para realizar adaptações e customizações do produto e do processo de produção, de acordo com as características locais de planta e de mercado. Essa descentralização aconteceu devido à necessidade de a empresa estar mais próxima do cliente e de obter uma resposta mais rápida. O que significa identificar a necessidade do cliente, traduzir em demanda de projeto, e executar em um menor tempo do que se o desenvolvimento fosse centralizado.

Mesmo sem levar em conta o fator tecnológico, a internacionalização da produção da Embraco faz com que as plantas no exterior desenvolvam uma interface com fornecedores locais, capaz de propiciar um melhor desenvolvimento local. Assim, a agilidade não está somente na resposta ao cliente, mas contempla toda a cadeia de suprimentos.

\subsubsection{Internacionalizando a pesquisa para a Ásia}

Um último ponto que merece ser abordado, é que a Embraco está considerando internacionalizar as atividades de pesquisa para a China, descentralizando essa função. A unidade foi escolhida por estar localizada em uma área que apresenta um alto crescimento de mercado e um grande número anual de formandos em engenharia e de pós-graduados, o que está transformando a região em um centro de excelência em pesquisa. Além disso, a China apresenta vantagens financeiras para a pesquisa, apesar de esbarrar ainda em questões de propriedade intelectual e de gestão do conhecimento. Como esses pontos dificultam a exposição da vantagem competitiva da empresa no país, ela optou por fazer a internacionalização de forma gradual. Essa atividade de pesquisa começará por meio de 
cooperações com universidades e parceiros, depois, com a contratação de novos profissionais, seguida pelo mapeamento das competências no mercado e, finalmente, será formada uma estrutura interna de pesquisa.

\subsubsection{MARCOPOLO}

\subsubsection{Internacionalização}

A partir de 1998, o mercado interno brasileiro deixou de oferecer perspectivas de crescimento para a Marcopolo, que já possuía parcela significativa do mercado. Considerando esse panorama, a direção da empresa decidiu internacionalizá-la, pautando sua estratégia em três bases principais: a internacionalização da produção, a verticalização e na tecnologia própria.

De acordo com o representante da Marcopolo, a internacionalização de uma empresa se dá quando esta decide produzir em plantas no exterior, ela própria ou em joint-ventures. Ele ressaltou que é importante não confundir contratos de cessão de tecnologia e exportação de componentes ou produtos completos com internacionalização. Com o passar do tempo, o país importador começa a exigir um maior grau de comprometimento por parte da empresa exportadora. Essa cobrança se dá, geralmente, na forma de barreiras tarifárias e percentuais crescentes de nacionalização progressiva, o que força a empresa a ir, gradualmente, internacionalizando sua produção.

Como forma de facilitar o estabelecimento de planos de nacionalização progressiva, a Marcopolo optou por verticalizar sua produção. Essa verticalização também possibilita uma maior flexibilidade na adaptação do produto ao uso e leis locais. Um terceiro ponto a favor da verticalização foi que, sem ela, a empresa corria o risco de ter a sua tecnologia copiada. Para o 
representante da Marcopolo, a única maneira de uma empresa ter liberdade de mercado é possuir sua própria tecnologia. Quando a empresa compra tecnologia fica impossibilitada de penetrar nos territórios do cedente, o que restringe o mercado e o processo de internacionalização. "O domínio da própria tecnologia é talvez o ponto mais forte de qualquer empresa na sua caminhada rumo à internacionalização", concluiu.

\subsubsection{P\&D}

O papel do P\&D na estratégia de internacionalização da Marcopolo é importante, devido às características do produto, das demandas dos clientes, e customizações necessárias para cada mercado. Assim, o P\&D da empresa é responsável por montar o escopo do projeto, analisar o grau de intensidade tecnológica dos possíveis parceiros e fornecedores locais, e conhecer os concorrentes locais. Praticamente, todas as atividades de P\&D estão localizadas na matriz. A estrutura da função é composta por um gerente de P\&D e dois supervisores subordinados a ele. Os demais níveis são formados por engenheiros, projetistas, desenhistas e designers. Toda essa equipe está subordinada ao diretor da divisão de engenharia.

\subsubsection{Desenvolvimento de produto}

A importância do desenvolvimento de produtos para a Marcopolo reside no fato de a empresa atuar em diversos mercados, que apresentam diferenças com relação às condições climáticas, exigências normativas etc. Além disso, clientes de um mesmo mercado podem necessitar de especificações diferentes. Essas diferenças de mercado impulsionaram a empresa a desenvolver um maior grau de customização. 
4.1.3.4 Internacionalização do desenvolvimento de produto

Salvo algumas exceções, todos os projetos tecnológicos são desenvolvidos com atuação direta da matriz. Uma das exceções é a contribuição das subsidiárias para a identificação das características específicas do mercado local, que são transferidas para a matriz por meio de reuniões de trabalho (presenciais ou por telefone), envio de informações por e-mail, análise conjunta de projetos. Essa participação da subsidiária - quando o projeto ou produto exige uma customização para o mercado de atuação - reduz o prazo de conclusão do projeto.

Além disso, a empresa mantém um setor de engenharia de desenvolvimento em duas subsidiárias no exterior, uma em Bogotá, Colômbia, e outra em Coimbra, Portugal. Na Colômbia, o motivo foi que o parceiro local da joint-venture já fabricava alguns produtos de seu portfólio próprio. Com a parceria, a Marcopolo decidiu manter esse setor desenvolvendo novos produtos e aperfeiçoando os existentes. Em Coimbra, a empresa decidiu manter o desenvolvimento local, uma vez que o mercado, além de apresentar baixo volume de vendas, exigia um tipo de produto muito distinto do produzido pela matriz.

A administração do desenvolvimento realizado nas subsidiárias é independente da gerência da matriz, e a direção de P\&D no Brasil não é responsável pelo trabalho de desenvolvimento no exterior. Da mesma forma, o orçamento de desenvolvimento das coligadas é definido localmente. A ação da matriz diz respeito ao acompanhamento, alinhamento das linhas mestras do design, e a definição dos parâmetros gerais no início de cada projeto, mas a coordenação é local. A comunicação entre a matriz e a administração dos projetos é feita por meio do supervisor da engenharia, que está fisicamente na coligada, e do gerente de desenvolvimento, alocado na matriz. Além disso, são feitas reuniões mensais entre 
engenharia e as áreas comerciais que representam estas coligadas, para alinhamento dos projetos de desenvolvimento.

\subsubsection{GERDAU}

\subsubsection{Internacionalização produtiva}

A Gerdau trabalha com duas linhas principais de produtos: tradicionais, e especiais. A linha de produtos tradicionais é a mais internacionalizada, com dezenas de plantas distribuídas na América do Sul e América do Norte. Já com relação aos produtos especiais, em meados de 2006, a empresa adquiriu sua primeira planta desses produtos especiais no exterior, na Espanha. Além das duas linhas principais, a empresa atua com uma terceira linha chamada de "zona cinza", composta por produtos intermediários, entre os tradicionais e os especiais. Esses produtos são desenvolvidos nas usinas de produtos especiais, porém fabricados nas usinas de produtos tradicionais.

\subsubsection{P\&D}

A inovação desenvolvida pela empresa geralmente é mais importante para o mercado nacional do que para o internacional, onde muitas vezes não é considerada uma novidade. Além disso, os entrevistados acreditam que, para o ramo de negócio de atuação da empresa, a importância do desenvolvimento tecnológico está em alinhar as necessidades dos clientes à capacidade produtiva da planta. A empresa ainda utiliza amplamente o benchmarking, e segundo as palavras de um dos entrevistados da empresa, "procura-se analisar as tendências do setor antes de implementar alguma ação de maior abrangência”. Dessa maneira, a 
estratégia da empresa é montar uma estrutura interna enxuta para P\&D, e completar sua expertise com auxílio externo de centros de referência em pesquisa no setor, em áreas em que a empresa ainda não domina. Assim, a função de P\&D da empresa trabalha de forma centralizada em uma usina de produtos especiais, em Charqueadas, no Rio Grande do Sul, pesquisando e desenvolvendo esses produtos, e prestando serviços para as usinas de produtos tradicionais, principalmente para o aperfeiçoamento de processos.

A atuação do P\&D está ligada ao desenvolvimento de novos produtos solicitados por clientes, à coordenação dos projetos de melhorias nos processos, e ao gerenciamento de projetos com parcerias e com centros de pesquisas. A função está vinculada estruturalmente ao departamento de tecnologia de produtos especiais (TPE), juntamente com a engenharia de produto e processos, engenharia de inspeção, laboratório de química e laboratório de metalurgia. Possui um corpo de oito pesquisadores, com capacitação técnica diferenciada para o desenvolvimento de ações em $\mathrm{P} \& \mathrm{D}$, estando organizada em forma de célula. Além das células, a empresa utiliza times multifuncionais de produção, que propiciam a integração de operadores, engenheiros de processo e suporte de $\mathrm{P} \& \mathrm{D}$, se necessário.

Segundo os entrevistados, historicamente, $30 \%$ dos investimentos em P\&D são aplicados em novos produtos e o restante em aperfeiçoamento de processos industriais. Contudo, devido ao aquecimento do mercado nos anos de 2004 e 2005, quase $90 \%$ foi investido em novos processos.

\subsubsection{Desenvolvimento de produto}

Como a empresa trabalha com três linhas de produtos, é preciso analisar o desenvolvimento de cada uma delas. A linha de produtos tradicionais é fundamentada em uma tecnologia madura, e sua estratégia de competitividade não está baseada na inovação, mas sim 
nos custos. Portanto, o papel do desenvolvimento nessa linha estaria ligado não ao produto, mas à diminuição dos custos do processo de fabricação.

Os produtos da "zona cinza" apresentam um valor agregado menor que os produtos especiais, mas um valor maior que os tradicionais. Os pedidos dessa linha "intermediária" são alocados nas plantas que fabricam o produto tradicional com a finalidade de aumentar seu valor gerado. A intensidade tecnológica exigida por esses produtos é maior do que a dos produtos tradicionais, por isso o papel do desenvolvimento é dar suporte tecnológico para essas unidades.

Os produtos especiais apresentam um maior valor agregado, pois atende clientes que exigem requisitos específicos. Nessa linha, o papel do P\&D é mais relevante. Na unidade visitada, cerca de $80 \%$ da produção está voltada para a indústria automotiva, e os $20 \%$ restantes são divididos entre outros setores, como motores elétricos, mineração, distribuição de energia etc. Como o produto final segue as especificações singulares para cada cliente, a produção da unidade é mediante encomenda, e os estoques são mantidos em níveis mínimos. Segundo os entrevistados, a inovação em produtos especiais está limitada às especificações de produto de acordo com requisitos estabelecidos pelos clientes. Contudo, é possível variar as composições químicas para alterar, por exemplo, as características do material, e assim atender a outros mercados.

\subsubsection{Internacionalização do desenvolvimento de produto}

Até 2005, a empresa possuía plantas no exterior destinadas somente à manufatura de produtos tradicionais. Com a aquisição, em 2006, de sua primeira planta produtiva na Espanha para a fabricação dos produtos especiais, ela incorporou um departamento de P\&D com cerca de 30 funcionários. Esse centro de P\&D da subsidiária espanhola tem expertise em 
todas as etapas do processo produtivo e, além disso, mantém parcerias, na Europa, com montadoras ou fornecedores da indústria automotiva, para desenvolvimento e fornecimento de produtos especiais. Ainda segundo um dos representantes da empresa, na aquisição dessa subsidiária, a existência de P\&D pesou favoravelmente. A Gerdau pretende ter maior participação em produtos especiais e, portanto, seguirá com expansões nessa área. Atualmente, ela trabalha para alinhar as práticas das unidades de P\&D do Brasil e as do exterior e, para isso, tem proporcionado intercâmbio de profissionais, com projetos estão sendo planejados em conjunto. A empresa pretende realizar um fórum anual de $\mathrm{P} \& \mathrm{D}$ (intercalado entre a Espanha e o Brasil) para a troca de experiências e apresentação de casos. Um fato muito importante é que os colaboradores espanhóis estão abertos a esta troca.

Mesmo tendo apenas essa área formal de P\&D no exterior, existem algumas ações de rotina, relativas a processos, principalmente de produção, que demandam suporte do $\mathrm{P} \& \mathrm{D}$ e são realizadas no exterior. Um exemplo dessas ações foi o desenvolvimento, em uma unidade dos EUA, por demanda de cliente local, de um produto especial para ser usado em cidades litorâneas.

Além disso, os funcionários transitam entre as várias unidades para favorecer a troca de conhecimento, e é comum a vinda de colaboradores estrangeiros para ao Brasil. Ao mesmo tempo, o sistema de informações da empresa possibilita que as melhores práticas sejam trocadas entre suas várias unidades, o que tem resultado em melhorias de processos. 


\subsubsection{TIGRE}

\subsubsection{Internacionalização}

A história da Tigre está intimamente ligada à inovação, que atualmente, está dirigida aos novos mercados, novos produtos e novos negócios. O foco em novos mercados está interligado à estratégia de internacionalização da empresa, que contempla tanto a produção quanto a comercialização dos produtos em novos países.

De acordo com os entrevistados, a internacionalização da produção da Tigre ocorreu para aumentar a velocidade de atendimento ao mercado estrangeiro. Assim, cada unidade fabrica os produtos específicos para o atendimento do mercado local.

\subsubsection{P\&D}

A função P\&D da Tigre foi estruturada de maneira a se integrar com as demais áreas da empresa, obedecendo a uma estratégia que visa uma maior precisão e sigilo, e ainda a redução do tempo de desenvolvimento. Atualmente, 83 funcionários trabalham na área de $\mathrm{P} \& \mathrm{D}$, que tem suas atividades centralizadas na matriz. Essa concentração de esforços de $\mathrm{P} \& \mathrm{D}$ deriva da necessidade de aproveitar a experiência e o reservatório de conhecimentos adquiridos pela Tigre ao longo dos anos. Um ponto interessante é que o profissional de P\&D da empresa passa metade do seu tempo de trabalho no laboratório, e a outra metade no campo. Isso permitiu ao pesquisador um maior convívio com o dia-a-dia das operações, verificando as ineficiências que possam ser resolvidas. Ao mesmo tempo, as atividades de P\&D estão mais voltadas para o desenvolvimento do que para a pesquisa. Segundo os entrevistados, a 
opção da empresa por não realizar pesquisa aplicada, é devido ao fato de a Tigre ser uma empresa industrial, focada no cliente final.

\subsubsection{Desenvolvimento de produto}

O processo de desenvolvimento de produtos se dá na forma de stage-gate. O início do processo ocorre com a identificação de uma necessidade do cliente ainda não atendida. A empresa utiliza como fontes de informação para a inovação, as obras em andamento, universidades, patentes, projetos de pesquisa financiados pela empresa, concorrentes e clientes, tanto internos quanto externos. Uma estratégia interessante utilizada pela TIGRE é a visita a clientes selecionados, para levantar as necessidades e conversar sobre mudanças que estes gostariam de ver nos produtos. Essa visita é feita por um grupo de funcionários ligados ao marketing e ao $\mathrm{P} \& \mathrm{D}$, e de uma empresa especializada em pesquisas. Ao serem detectadas, as demandas são transformadas em projeto primário, e com o cálculo de especificações referentes ao material utilizado, retorno financeiro, tempo de execução, meios de produção necessários, entre outras. O projeto é então avaliado por um comitê, formado pela alta administração da empresa, e por gerentes de áreas. Este é o primeiro ponto de avaliação. Até

chegar ao comitê, o projeto é de responsabilidade do $\mathrm{P} \& \mathrm{D}$, mas após a avaliação, a responsabilidade passa para a engenharia.

\subsubsection{Internacionalização do desenvolvimento de produto}

A empresa não possui desenvolvimento de produtos no exterior. Contudo, como as unidades atendem à demanda local, elas são utilizadas para detectar mudanças no comportamento do mercado e o surgimento de novas tendências. Dessa forma, quando novas 
propostas de projetos surgem nas plantas, são passadas para a matriz que os avalia e seleciona. Esses novos projetos são desenvolvidos pelo P\&D no Brasil e, posteriormente, são produzidos nas unidades que os propuseram.

De acordo com os entrevistados, um P\&D descentralizado geograficamente, desestabilizaria a organização da empresa e diminuiria a velocidade de atuação e a sinergia entre as áreas.

\subsubsection{SMAR}

\subsubsection{Internacionalização}

A internacionalização da Smar teve iniciou no fim dos anos 1980, quando um de seus pesquisadores mudou-se para Nova Iorque e, por iniciativa própria, começou a realizar desenvolvimentos para a empresa. $O$ pesquisador percebeu que a principal vantagem de fazer desenvolvimentos nos EUA era a rapidez na entrega dos componentes. A internacionalização da empresa foi contemplada dentro do segundo plano geral de desenvolvimento (PGD 2) da empresa. Foram montados um escritório e uma fábrica em Nova York, sendo estes implantados de forma adaptativa e gradual, de acordo com as oportunidades e condições da empresa, que seriam o investimento com dinheiro próprio, o retorno das primeiras vendas realizadas e exigências dos mercados em termos de qualidade e regulamentações.

Além dessa unidade pioneira, a empresa inaugurou, alguns anos depois, outra fábrica em Houston, implantada em uma região próxima de empresas concorrentes, que oferecia vantagens em termos de custo. As subsidiárias no exterior operam independentemente da matriz, mas seu direcionamento estratégico é orientado pelas diretrizes do conselho administrativo do grupo no Brasil. 


\subsubsection{P\&D}

A importância do P\&D para a empresa está na necessidade dela se manter atualizada e inovadora em seu setor de atuação. Para coordenar as atividades de $\mathrm{P} \& \mathrm{D}$ realizadas na matriz, a empresa estabeleceu os Planos Gerais de Desenvolvimento (PGD), baseados nas diretrizes da alta administração. Atualmente a empresa está em seu quarto PGD.

A pesquisa na empresa já foi mais atuante, porém, diante do aumento da concorrência, os pesquisadores foram alocados em projetos. Então, atualmente, o P\&D da empresa está voltado para o desenvolvimento de produto e processos. Além de se responsabilizar pela inovação, o P\&D atua também na criação de novos equipamentos para a manufatura dos produtos da empresa.

\subsubsection{Desenvolvimento de produto}

A diretoria define os produtos a serem desenvolvidos após consulta ao mercado e aos setores comercial e marketing da empresa. A partir disso é definido um time funcional para cada produto que fica responsável pela elaboração e aprovação de um documento com os requisitos de negócio do produto, o DRE - documento de requisitos do projeto, nesta fase todos os setores da empresa são envolvidos.

O projeto é dividido em componentes e então, traça-se o DPL - plano de desenvolvimento do projeto. São formadas equipes que desenvolvem e testam os componentes e, no fim, integram o projeto, produzindo um protótipo para validação. Após validação é feito o DRS - documento dos resultados de saídas do projeto e então submetido a aprovação do time que participou da definição do DRE. O projeto então entra na fase de 
manutenção onde as alterações são documentadas e registradas no RHP - documento de histórico do projeto.

\subsubsection{Internacionalização do desenvolvimento de produto}

Ambas as unidades do exterior realizam pesquisa e desenvolvimento, fabricam e comercializam produtos próprios, desenvolvidos localmente para o mercado global. Os fabricados em Houston estão voltados para a linha de Controladores Lógicos Programáveis, enquanto que os de Nova York focam na linha de barreiras de segurança intrínseca e transmissores de temperatura e de nível. Um fato importante é que o P\&D realizado no exterior é independente do realizado no Brasil, tendo autonomia em relação ao diretor de P\&D brasileiro.

\subsection{CONFRONTO DOS CASOS COM O REFERENCIAL}

Nesta seção, os casos são confrontados com o referencial teórico levantado. Primeiramente foi analisada a internacionalização da produção das empresas, usando como referências o Modelo de Uppsala, a Teoria do Paradigma Eclético, as Teorias Estratégicas da Internacionalização, e o Modelo de Internacionalização Produtiva de Ferdows.

\subsubsection{Modelo de Uppsala}

Este modelo postula que o processo de internacionalização é feito de maneira gradual, primeiro com exportações e, à medida que a empresa obtém um maior conhecimento do mercado, vai aumentando seu comprometimento com o mesmo. "A preocupação maior dos 
teóricos de Uppsala era explicar o processo de internacionalização e as forças que atuam no decorrer desse processo, e não os motivos que levam as empresas a investir no exterior" (ROCHA; ALMEIDA, 2006; p. 25).

Todas as empresas estudadas iniciaram suas atividades internacionais pelas exportações, revenda e distribuição, antes de instalar suas plantas. Assim, do ponto de vista geral, elas foram gradualmente aumentando seu comprometimento com o mercado, por meio de suas operações internacionais.

Os casos estudados nos levam a considerar que, além de um comprometimento com o mercado, existiria também um comprometimento com a internacionalização da empresa. Assim, a empresa já internacionalizada, traçaria suas estratégias de entrada para novos paises, levando em conta não só o novo mercado, país ou região, mas todos os lugares nos quais já atua. Dessa maneira, em certas unidades, as formas de atuação não evoluiriam conforme o modelo, mas permaneceriam nos estágios iniciais sendo supridas pelas fábricas da empresa em outras localidades. Assim, não é somente o comprometimento com o mercado que direciona o processo de internacionalização, mas como o novo mercado interage com os demais onde a empresa já atua, e qual seria a evolução mais vantajosa para a internacionalização da empresa.

Por exemplo, a WEG começou com exportações, utilizando representantes e escritórios próprios, e depois, instalando plantas produtivas no exterior, essa divisão de estágios está de acordo com o Modelo de Uppsala. Contudo, a empresa utiliza os três estágios simultaneamente, o que demonstra que, para cada localidade ela tem um comprometimento diferente. O aumento desse comprometimento em uma localidade não levaria, necessariamente, a uma evolução de uma unidade de revenda para uma planta produtiva, não fazendo ela mudar sua estratégia de atuação em determinada localidade. Isso pode demonstrar que existem outros fatores que influenciam a decisão de internacionalização da WEG. Assim, 
apesar da estratégia inicial da firma evoluir na direção do Modelo de Uppsala, os determinantes de como essa evolução aconteceria estariam contidos no Paradigma Eclético e / ou nas Teorias Estratégicas da Internacionalização.

Ainda no caso da WEG, os fatores que levaram à escolha das localizações das plantas foram à necessidade de crescimento, redução dos custos logísticos, e do tempo de atendimento ao cliente. Com essa finalidade, a empresa montou uma rede de plantas produtivas que abastecem seus mercados. O comprometimento com determinada região não aumenta até que seja construída uma planta produtiva; mas as vantagens e desvantagens de cada localidade influenciam tanto a estratégia de entrada utilizada, quanto à evolução desse comprometimento. É importante notar que se o foco estratégico de atuação no país mudar, o comprometimento da empresa se altera, podendo até fazer uma planta regredir, como foi notado no caso da EMBRACO, cuja planta italiana está passando por um processo de "desinvestimento" gradual para alcançar um ponto sustentável. Isso demonstra que o grau de comprometimento de uma empresa pode variar ao longo do tempo e que essa variação não é, necessariamente, sempre positiva. Ao mesmo tempo, o interesse da empresa com a região européia não diminuiu, tanto que isso levou a empresa a implantar uma nova planta na Eslováquia, que apresenta vantagens competitivas em relação à planta italiana. Assim, podese especular sobre a possibilidade do comprometimento migrar de um país para outro, mas sem reduzir o interesse pelo mercado.

Por outro lado, mudanças dos aspectos culturais e econômicos na Ásia, fizeram a EMBRACO planejar a instalação de um centro de pesquisa na China, demonstrando que o grau de comprometimento da empresa com a região estaria aumentando. Os motivos apontados para isso seriam a alta taxa de crescimento do mercado e ao aumento da mão-deobra especializada. A empresa está montando, na China, uma estratégia de internacionalização de pesquisa gradual, primeiro firmando acordos com universidades e 
centros de pesquisa na região e depois implantando o seu próprio centro, o que demonstrando que, dentro de um mesmo estágio de comprometimento, existem subdivisões.

O grau de aumento do comprometimento difere, naturalmente, de empresa para empresa. A SMAR, por exemplo, teve um aumento tão significativo do seu comprometimento, que levou a empresa a instalar, em apenas um ano, um escritório e uma fábrica em Nova York. E, depois de algum tempo, a abriu sua segunda fábrica no país, em Houston. Já o caso da MARCOPOLO demonstrou que o comprometimento de uma empresa pode ser influenciado por ações externas, derivadas das mudanças políticas de uma região. A empresa inicia sua internacionalização por meio da exportação de produtos acabados, e, com o passar do tempo, o país onde ela atua passa a obrigar que parte desse produto seja feita em fábricas locais. Assim, para continuar operando na região, é obrigada a aumentar seu compromisso, alocando fases da produção nos países anfitriões, o que impulsiona a empresa a internacionalizar suas plantas produtivas.

É preciso notar que o setor de atuação e o processo de produção também podem influenciar o comprometimento com a região e a internacionalização. A Tigre internacionalizou sua produção para alguns países, mas em outros continuou a operar por meio de revendas e distribuidores. Contudo, a Gerdau, diferentemente das demais empresas, apresenta uma distribuição geográfica singular, característica do seu negócio. A implantação de uma nova siderúrgica depende de um valor de investimento inicial alto, e sua localização deve ficar próxima dos mercados consumidores e das fontes de energia, o que levou a empresa a optar por comprar usinas já estabelecidas. 


\subsubsection{Paradigma Eclético}

O Paradigma Eclético procura explicar os motivos que induzem uma empresa a tomar a decisão de produzir no exterior. Para competir nos países estrangeiros, as empresas devem desenvolver vantagens que compensem os custos de operação nestas localidades. Cinco empresas estudadas foram motivadas a internacionalizar sua produção, principalmente, pela necessidade de estarem próximas aos clientes, sendo as vantagens locacionais, foram, portanto, preponderantes. O único caso diferente foi o da SMAR que teve um início de internacionalização caracterizado como não planejado, segundo seus representantes. Contudo, ao perceber que a região era promissora, a empresa montou um plano de internacionalização e, em pouco tempo, instalou um escritório e uma fábrica. A vantagem apresentada pela rapidez na aquisição de componentes para a montagem dos produtos foi o fator que levou a empresa a se internacionalizar.

No caso da TIGRE, a internacionalização está ligada à procura de novos mercados, assim, a vantagem perseguida pela empresa foi estar próxima do cliente, para responder o mais rápido possível às demandas. Também na internacionalização da GERDAU, o motivo foi a necessidade de estar próximo ao cliente. Contudo, o fator preponderante para a decisão não foi só o de responder mais rápido à demanda, mas, também, de fornecer produtos com custos mais competitivos, e ao adquirir plantas já construídas no exterior, ficou também com a carteira de clientes. No caso da aquisição da usina de produtos especiais, além da vantagem descrita acima, teve também a vantagem locacional de aumentar a participação de mercado nessa linha de produtos.

A vantagem proprietária mencionada nos casos é a da tecnologia própria, porém

algumas das empresas estudadas não possuíam essa vantagem no início e só foram desenvolvê-la com o passar do tempo. 
A WEG e a EMBRACO, por exemplo, firmaram contratos para obtenção de tecnologia no exterior. Contudo, apesar desses contratos terem lhes possibilitado a produção de melhores produtos, eles não incorporavam tecnologias de ponta. Dessa forma, as empresas ficavam dependentes das suas "fornecedoras de tecnologia". O investimento em P\&D surgiu como uma forma da empresa desenvolver sua tecnologia própria, não reinventando a roda, mas desenvolvendo a competência de fazê-la. Para a MARCOPOLO, a tecnologia própria é tão importante que a empresa, indo na contra-mão da indústria automobilística, prefere verticalizar toda sua produção, mantendo suas competências internalizadas.

Outro ponto seria o das "desvantagens específicas" associadas à firma por ser uma empresa brasileira. Como descrito por um entrevistado da WEG, a questão era: o que uma empresa brasileira tem a oferecer em termos de tecnologia, que uma firma estrangeira já não oferece? Ela contornou esse revés trazendo clientes para visitar sua matriz e verificar seus parques fabris, mostrando que a empresa também dispunha de competências tecnológicas. Contudo, foram necessários dez anos para que ela obtivesse o reconhecimento. Um caso semelhante foi relatado pela SMAR, alguns dos representantes da empresa solicitaram que ela evitasse ou retirasse o selo "Made in Brazil" das embalagens dos produtos. Com o passar do tempo, a empresa conseguiu o reconhecimento de qualidade de produção tecnológica e isso deixou de ser solicitado.

Por fim, as vantagens de internalização são as que norteiam as ações da empresa em relação ao deixar de explorar suas vantagens específicas, cedendo direitos temporários a parceiros não associados. Ou seja, uma empresa pode associar-se a um revendedor, distribuidor ou fabricante no exterior, ao invés dela mesma realizar o investimento. Com relação às atividades de pesquisa e desenvolvimento, as empresas estudadas buscaram formar acordos de cooperação com Universidades e centros de excelência para a realização pesquisa 
aplicada, além de realizarem desenvolvimento de produtos e processos com seus fornecedores.

\subsubsection{Teoria de Estratégia de Internacionalização}

Esta teoria parte do princípio que a configuração e a coordenação concebidas pela empresa, são importantes no processo de internacionalização da mesma. A análise dos casos estudados demonstrou que as empresas possuem estratégias e estruturas próprias de internacionalização. A GERDAU prefere utilizar aquisições como modo de entrada no exterior, aproveitando os ganhos de escala. Isso pode ser uma estratégia da empresa para conseguir entrar nos mercados já com uma participação. A WEG utilizou essa estratégia no México, e conseguiu, após a aquisição, um aumento de sua participação de mercado na região. Já a EMBRACO está considerando internacionalizar a pesquisa para a China, isto devido ao crescimento do mercado e ao aumento de mão-de-obra especializada no país. A TIGRE internacionalizou sua produção para atender melhor seus clientes locais, porém seu P\&D ficou centralizado para utilizar a "massa crítica" da empresa, obter ganhos de escala, e por que, segundo os entrevistados, o P\&D descentralizado acarretaria aumento do custo de organização e coordenação. Esse é o mesmo caso da MARCOPOLO, que capta no exterior as tendências de mercado e tecnológicas, e centraliza suas operações de P\&D na matriz. Porém em Portugal e na Colômbia, pelas peculiaridades dos mercados, permite que haja desenvolvimento de produtos. Esse desenvolvimento de produtos é coordenado localmente, e não presta contas diretamente ao diretor de $\mathrm{P} \& \mathrm{D}$ da matriz. A mesma estrutura independente foi verificada também na SMAR, que optou por uma estrutura autônoma para suas subsidiárias, ficando a coordenação à cargo do conselho administrativo. 


\subsubsection{Internacionalização de atividades produtivas}

O Modelo de Ferdows, apresentado na seção 2.1.3, estuda os papéis que as plantas no exterior podem assumir. Para classificar esses papéis, o modelo trabalha em duas dimensões: as razões estratégicas e as competências das plantas.

Nesta pesquisa, para avaliar a razão estratégica da internacionalização da planta, foi utilizado o principal motivo apresentado pelos entrevistados para determinar a localização da fábrica. Para o caso de competência da planta, foram utilizadas as informações colhidas sobre o desenvolvimento de produtos. Se as plantas apresentavam um desenvolvimento próprio de produtos antes e depois da internacionalização continuaram com o desenvolvimento, elas foram consideradas detentoras de uma competência alta, Mas se o desenvolvimento não era determinante para atuação das plantas, então elas foram consideradas com baixa competência.

De uma maneira geral, a localização das plantas privilegiou a próximidade com o mercado, e foram, portanto, classificadas como Server ou Contributor, dependendo da sua competência. A SMAR possui duas fábricas no exterior, ambas nos Estados Unidos, com um gerenciamento independente da empresa no Brasil, assim, elas foram classificadas como Lead. No caso da WEG são seis plantas Server e uma Contributor. A planta Contributor tem uma competência maior que as demais, pois já fabricava os produtos à prova de explosão. No caso da GERDAU, das plantas no exterior, a analisada foi a planta da Espanha que trabalha com aços especiais, ela pode ser classificada, como Lead. Essa planta, adquirida no fim de 2006, tem competências para a fabricação de produtos especiais.

Das três plantas que a EMBRACO tem no exterior, duas podem ser classificadas como Server e uma como Contributor. A MARCOPOLO possui cinco plantas e três delas são classificadas como Server. As fábricas restantes (Portugal e Colômbia) podem ser 
classificadas como Contributor, pois operam sem a coordenação da matriz. Já as seis plantas da TIGRE podem ser classificadas como Server.

O modelo descreve caminhos que podem levar as plantas produtivas a papéis estratégicos mais altos. Isso seria conseguido com o aumento da competência da planta, focalizando nos ativos intangíveis, como aprendizagem com fornecedores, clientes, competidores e centros de pesquisa e a atração global de talentos. Esses caminhos podem ser utilizados para analisar as mudanças estratégicas e as competências das plantas o que possibilita analisar sua dinâmica.

Na EMBRACO, a fábrica chinesa, considerada Server, está passando por um processo semelhante pois, a empresa está cogitando transferir para ela, atividades de P\&D que antes eram conduzidas somente na matriz. Assim, o foco estratégico da planta está mudando da proximidade de clientes, para o acesso a habilidades e conhecimentos. Isso pode levar a uma reclassificação da planta para Lead. Ainda na EMBRACO, a planta da Itália está sofrendo um processo reverso. Na época da aquisição, a planta possuía uma linha de produtos que a matriz não tinha, e isso possibilitou à empresa internalizar novas competências. Apesar de ter desvantagens a definição da estratégia de "desinvestimento" conseguiu fazer com que a planta, focando em produtos de alto valor agregado, se tornasse operacionalmente sustentável. Porém, se a situação se tornasse insustentável, uma planta que foi classificada como Lead, poderia ser re-classificada como Outpost. Outro caso é o da planta da WEG em Portugal. Nesta unidade, a competência em produzir produtos à prova de explosão foi transferida para o Brasil, mas a unidade permaneceu com seu desenvolvimento o que a classifica como Contributor. No quadro 5.2 estão sumarizadas as empresas e os tipos de plantas que possuem. Foram analisadas 24 plantas, sendo que a maioria apresenta competências que podem ser aperfeiçoadas para aumentar sua contribuição para a rede da empresa. 


\begin{tabular}{|l|l|}
\hline \multicolumn{1}{|c|}{ Empresa } & \multicolumn{1}{c|}{ Tipo de plantas (de acordo com Ferdows) } \\
\hline EMBRACO & Uma LEAD e duas SERVER \\
\hline GERDAU & Uma LEAD \\
\hline TIGRE & Seis SERVER \\
\hline MARCOPOLO & Duas CONTRIBUTOR e três SERVER \\
\hline SMAR & Duas LEAD \\
\hline WEG & Seis SERVER e uma CONTRIBUTOR \\
\hline
\end{tabular}

Nas próximas três seções, serão utilizados os modelos de internacionalização de $\mathrm{P} \& \mathrm{D}$, apresentados na seção 2.3.9 do referencial, para análise das características de cada um dos casos, do posicionamento de seu centro de gravidade, e dos tipos e funções de $\mathrm{P} \& \mathrm{D}$ realizadas das suas unidades no exterior.

\subsubsection{Modelo de gestão de P\&D internacionalizado}

O primeiro modelo a ser utilizado é o de Gestão de P\&D Internacionalizado de Gassmann e Von Zedwitz (1999). As empresas analisam os benefícios e ameaças da internacionalização do $\mathrm{P} \& \mathrm{D}$ e, baseadas nessa análise, decidem sobre a centralização ou não da função. Dos seis casos estudados, a SMAR e a EMBRACO foram as únicas que, além de internacionalizar as atividades produtivas, por decisão própria, internacionalizaram, também as atividades ligadas ao desenvolvimento de produtos. Para a WEG, MARCOPOLO e GERDAU, a aquisição de instalações no exterior forneceu instalações de desenvolvimento de produto que foram incorporadas à empresa. A TIGRE foi a única empresa do estudo que apresentou o desenvolvimento de produto totalmente centralizado.

Segundo este modelo, tem-se o desenvolvimento de produtos centralizado etnocentricamente para quatro empresas: WEG, MARCOPOLO, GERDAU e TIGRE. Porém, para a MARCOPOLO, as unidades em Portugal e Colômbia, estão descentralizadas 
atuando independentemente da matriz. Para a WEG, sua unidade em Portugal atua de forma descentralizada, mas com a coordenação das atividades feitas pela matriz. E para a GERDAU, sua unidade na Espanha começa a ser inserida nas atividades de $\mathrm{P} \& \mathrm{D}$ da empresa, então pode ainda ser considerada descentralizada. A EMBRACO apresenta duas configurações uma para o desenvolvimento de tecnologia dominada e outro para a tecnologia não dominada. Para a tecnologia dominada sua configuração se assemelha descentralizado policentricamente, já para as tecnologias não dominadas, seu desenvolvimento de produtos é centralizado etnocentricamente. Para a SMAR as subsidiárias estrangeiras apresentam um alto grau de autonomia em relação à matriz, o que configuraria um caso extremo de descentralização policêntrica, da mesma forma, pode-se considerar a TIGRE como o caso extremo de centralização etnocêntrica.

De acordo com GALINA (2003), as transnacionais de origem estrangeira apresentam seu P\&D disperso como forma de captar as novidades tecnológicas mundiais. Contudo, as multinacionais estudadas, indo na contra-mão das estrangeiras, centralizam sua pesquisa e desenvolvimento de inovações e dispersam o desenvolvimento de tecnologias dominadas. Isso pode ser derivado da necessidade de internalizar na matriz as novas competências, antes de dar prosseguimento a desenvolvimentos posteriores.

\subsubsection{O modelo de Chiesa}

De acordo com este modelo, uma empresa pode internacionalizar seu P\&D por fatores de demanda ou de tecnologia. Cada um desses fatores teria estratégias diferentes para a internacionalização do $\mathrm{P} \& \mathrm{D}$ das empresas. $\mathrm{O}$ fator de demanda determinaria uma descentralização seguindo a internacionalização da produção e do marketing, enquanto que o 
fator tecnologia, definiria uma descentralização resultante da construção de laboratórios geograficamente dispersos.

De acordo com o modelo, os laboratórios de pesquisa descentralizados da SMAR serviriam para obter acesso a recursos específicos e para monitorar o desenvolvimento tecnológico. $\mathrm{O}$ resultado das entrevistas evidencia que o rápido acesso aos componentes foi o motivo principal para a internacionalização.

Por sua vez, a TIGRE apresenta seus laboratórios, tanto de pesquisa quanto de desenvolvimento, centralizados na matriz. Isso aumenta a eficiência e a agilidade dos processos internos, porém desacelera o aprendizado do mercado. Essa deficiência é suprida, no entanto, pelo monitoramento feito por gerentes alocados nas plantas do exterior.

A EMBRACO apresenta uma divisão na gestão de seu desenvolvimento. Enquanto seus laboratórios de tecnologias não dominadas permanecem centralizados na matriz, seus laboratórios de desenvolvimento de tecnologias dominadas são descentralizados, oferecendo um rápido aprendizado do mercado e atendimento a clientes das diferentes regiões de atuação.

A WEG, a GERDAU e a MARCOPOLO apresentam grande parte de seu desenvolvimento centralizado na matriz. Apenas as fábricas que já possuíam o desenvolvimento de produtos mantiveram essa função. A GERDAU na Espanha mantém laboratórios de pesquisa e de desenvolvimento, a fim de que a empresa utilize esses laboratórios para acesso a recursos específicos e diminua custos de transição entre o P\&D e a produção. Da mesma forma, os laboratórios de desenvolvimento da WEG em Portugal, e a MARCOPOLO na Colômbia e em Portugal são usados para diminuir os custos de transação entre o P\&D e a produção.

Um ponto importante é que cinco das empresas estudadas alegam que optaram por internacionalizar suas atividades produtivas, com a finalidade de aumentar a proximidade com 
os clientes. Já a SMAR, alegou que internacionalizou suas atividades de desenvolvimento para os EUA como forma de obter um melhor acesso à tecnologia.

Para determinar o foco estratégico de P\&D das empresas tem-se de analisar se essa fuanção está baseada na habilidade de desenvolver tecnologias que gerem correntes de inovação a partir de suas próprias pesquisas, ou se, baseiam sua competência na habilidade de explorar e aplicar a tecnologia em novos produtos e processos. No início as empresas não possuíam tecnologia própria e tiveram que explorar e aplicar a tecnologia de terceiros em seus produtos e processos. Contudo, conforme foram se internacionalizando e enfrentando a concorrência de multinacionais, elas foram forçadas a desenvolver sua própria tecnologia. Assim, seu foco estratégico de $\mathrm{P} \& \mathrm{D}$, que no início era baseado na exploração do ambiente tecnológico e adaptação dos produtos para o mercado brasileiro, migrou para a o desenvolvimento de tecnologias com as próprias pesquisas. Dessa forma, todas as empresas foram classificadas como voltadas para a pesquisa.

\subsubsection{O modelo de Ronstadt e Reddy}

Os dois primeiros modelos foram utilizados para avaliar a função $P \& D$ da empresa quanto a sua configuração, coordenação e foco estratégico. Este terceiro, por sua vez, analisa as unidades do exterior de cada empresa de acordo com as características das atividades realizadas. Assim, para fazer a classificação dos casos, foram levadas em conta as características das atividades de desenvolvimento de produtos realizadas nessas unidades. Cada unidade foi avaliada, primeiramente, pela capacidade de gerar tecnologias e novos produtos para ser utilizada pela matriz, ou atuando apenas para a transferência de tecnologia; e depois, pelo impacto geográfico da tecnologia gerada, ou seja, a importância do produto gerado para os mercados local, regional ou global. 
As duas subsidiárias da SMAR foram classificadas como unidades de tecnologia corporativa e global, pois além de desenvolverem produtos para o mercado global geram tecnologia básica de longo prazo para uso corporativo. A unidade espanhola da GERDAU desenvolve produtos e processos para a maioria dos mercados, tem competências próprias exploradas pela matriz, e foi classificada como uma unidade de tecnologia corporativa e global. As duas unidades da MARCOPOLO que possuem desenvolvimento de produtos, foram classificadas como unidades de tecnologia nativa, enquanto que as demais foram classificadas como unidades de transferência de tecnologia. O mesmo se deu com as unidades da TIGRE, e as unidades da WEG, com a exceção da unidade portuguesa da WEG, que foi classificada como uma unidade de tecnologia corporativa e regional, pois, além de fabricar os produtos à prova de explosão para o mercado europeu, faz desenvolvimento desse tipo de produto e transfere essas competências para a matriz. No que se refere às unidades da Embraco, a italiana é uma unidade de tecnologia global, e a da Eslováquia seria uma unidade de tecnologia regional. Já a chinesa é uma unidade de tecnologia regional que pode vir a se tornar uma unidade de tecnologia corporativa e global.

No quadro 4.3 tem-se sumarizadas as informações sobre internacionalização de P\&D para cada empresa estudada. 


\begin{tabular}{|c|c|c|c|}
\hline Empresa & $\begin{array}{c}\text { Modelo de Gasssman e Von } \\
\text { Zedwitz (1999; 2002) }\end{array}$ & $\begin{array}{c}\text { Modelo de Chiesa (1995; } \\
\text { 2000) }\end{array}$ & $\begin{array}{c}\text { Modelo de Ronsdatd (1978) } \\
\text { e Reddy (1997) }\end{array}$ \\
\hline Embraco & $\begin{array}{l}\text { Centralizado } \\
\text { etnocentricamente / } \\
\text { Descentralizado } \\
\text { policentricamente }\end{array}$ & $\begin{array}{l}\text { Desenvolvem tecnologias } \\
\text { que geram correntes de } \\
\text { inovação a partir de seuas } \\
\text { próprias pesquisas. }\end{array}$ & $\begin{array}{c}\text { Unidade Italiana: Tecnologia } \\
\text { Global } \\
\text { Unidade Eslovaca: } \\
\text { Tecnologia Regional } \\
\text { Unidade Chinesa: } \\
\text { Tecnologia Regional que } \\
\text { pode se tornar uma unidade } \\
\text { de Tecnologia Corporativa. }\end{array}$ \\
\hline Gerdau & $\begin{array}{c}\text { Centralizado } \\
\text { etnocentricamente, com uma } \\
\text { unidade descentralizada }\end{array}$ & $\begin{array}{l}\text { Desenvolvem tecnologias } \\
\text { que geram correntes de } \\
\text { inovação a partir de seuas } \\
\text { próprias pesquisas. }\end{array}$ & $\begin{array}{c}\text { Unidade Espanhola: } \\
\text { Tecnologia Corporativa e } \\
\text { Global } \\
\text { Demais unidades: } \\
\text { Transferência de Tecnologia } \\
\end{array}$ \\
\hline Tigre & $\begin{array}{c}\text { Centralizado } \\
\text { etnocentricamente (caso } \\
\text { extremo) }\end{array}$ & $\begin{array}{l}\text { Desenvolvem tecnologias } \\
\text { que geram correntes de } \\
\text { inovação a partir de seuas } \\
\text { próprias pesquisas. }\end{array}$ & $\begin{array}{c}\text { Unidades de Transferência } \\
\text { de Tecnologia }\end{array}$ \\
\hline WEG & $\begin{array}{c}\text { Centralizado } \\
\text { etnocentricamente, com uma } \\
\text { unidade descentralizada. }\end{array}$ & $\begin{array}{l}\text { Desenvolvem tecnologias } \\
\text { que geram correntes de } \\
\text { inovação a partir de seuas } \\
\text { próprias pesquisas. }\end{array}$ & $\begin{array}{c}\text { Unidade Portuguesa: } \\
\text { Tecnologia Corporativa e } \\
\text { Regional } \\
\text { Demais unidades: } \\
\text { Transferência de Tecnologia }\end{array}$ \\
\hline Marcopolo & $\begin{array}{l}\text { Centralizado } \\
\text { etnocentricamente, com duas } \\
\text { unidades descentralizadas. }\end{array}$ & $\begin{array}{l}\text { Desenvolvem tecnologias } \\
\text { que geram correntes de } \\
\text { inovação a partir de seuas } \\
\text { próprias pesquisas. }\end{array}$ & $\begin{array}{c}\text { Unidades em Portugal e } \\
\text { Colômbia: Tecnologia } \\
\text { Regional } \\
\text { Demais unidades: } \\
\text { Transferência de Tecnologia } \\
\end{array}$ \\
\hline Smar & $\begin{array}{c}\text { Descentralizado } \\
\text { policentricamente (caso } \\
\text { extremo) }\end{array}$ & $\begin{array}{l}\text { Desenvolvem tecnologias } \\
\text { que geram correntes de } \\
\text { inovação a partir de seuas } \\
\text { próprias pesquisas. }\end{array}$ & $\begin{array}{c}\text { Unidades Americanas: } \\
\text { Tecnologia Corporativa e } \\
\text { Global }\end{array}$ \\
\hline
\end{tabular}

Quadro 4.3 - Quadro sinóptico dos modelos de internacionalização de P\&D e as empresas estudadas 


\section{V - CONSIDERAÇÕES FINAIS}

\subsection{CONCLUSÕES}

O problema de pesquisa proposto por este trabalho procurou saber se o processo de internacionalização das multinacionais brasileiras motivou a internacionalização de suas atividades de desenvolvimento de produtos. Para responder à questão, foram conduzidos seis estudos de caso em empresas multinacionais brasileiras, identificando a estratégia de P\&D dessas organizações, verificando a estruturação das atividades de desenvolvimento de produtos e, ainda, identificando se algumas dessas atividades eram realizadas no exterior.

De forma geral, as empresas estudadas internacionalizaram seu desenvolvimento de produtos por motivos de adaptações necessárias aos mercados ou às regulamentações (WEG, MARCOPOLO, EMBRACO, GERDAU, SMAR), e, também, por motivos de acesso mais rápido a recursos específicos (SMAR). Porém, a parte internacionalizada ainda é pequena para a maior parte dos casos. A TIGRE foi a única empresa que manteve seu desenvolvimento de produto totalmente centralizado na matriz, e isso foi feito como forma de resguardar suas competências e de minimizar os custos e o tempo de desenvolvimento. Essa internacionalização ocorreu em plantas novas (EMBRACO, SMAR), em plantas adquiridas (EMBRACO, WEG, MARCOPOLO, GERDAU) e em plantas fruto de joint-ventures (MARCOPOLO). O importante é que nas duas últimas formas, o desenvolvimento já existia anteriormente, e por características de mercado ou de certificação, as empresas optaram por mantê-lo no exterior. Outro ponto observado é que as plantas situadas na Europa Ocidental possuem um desenvolvimento de produtos de maior valor agregado, por motivos de certificação e de mercado. O quadro 5.1 apresenta os resultados finais. 


\begin{tabular}{|c|c|}
\hline EMPRESA & $\begin{array}{c}\text { O processo de internacionalização das MNB motivou a } \\
\text { internacionalização de suas atividades de desenvolvimento de } \\
\text { produtos? }\end{array}$ \\
\hline TIGRE & Não. \\
\hline MARCOPOLO & Sim, mas só onde já existia desenvolvimento. \\
\hline WEG & Sim, mas só onde já existia desenvolvimento. \\
\hline GERDAU & Sim, mas só onde já existia desenvolvimento. \\
\hline EMBRACO & Sim, mas somente para as tecnologias já dominadas. \\
\hline SMAR & Sim. \\
\hline
\end{tabular}

Quadro 5.1 - Quadro de respostas para o problema de pesquisa

As empresas não realizam pesquisa básica, mas sim a pesquisa aplicada, no Brasil e no exterior, inclusive junto a Universidades, centros de pesquisas, ou com consultores especializados. Narula e Duyster (2004) e Von Zedwitz (2005) sugeriram que as empresas podem usar alianças como forma de internacionalização, e isso foi encontrado em quatro dos casos estudados. A EMBRACO que, ao invés de internacionalizar suas unidades de pesquisa para os centros de excelência, assinou contratos de cooperação tecnológica, criando uma rede de conhecimento no exterior, utilizada para inovar produtos e processos. Da mesma forma, a WEG utiliza acordos com universidades e de consultorias externas no desenvolvimento de novos produtos. A MARCOPOLO assinou contrato com uma universidade portuguesa para ajudá-la a desenvolver produtos para o mercado europeu. A GERDAU, além de fazer o monitoramento do mercado por meio do benchmarking, realiza projetos de desenvolvimento com parceiras e centros de pesquisa.

A internacionalização das empresas não foi motivada apenas pela procura de vantagens no exterior, mas, também, pelo baixo crescimento do mercado interno. Assim, a forma encontrada pelas empresas para continuar a crescer foi procurar mercados externos, tanto em países desenvolvidos quanto em países em desenvolvimento.

As MNB estudadas indicaram que o desenvolvimento de uma tecnologia própria foi também decisivo para o crescimento. A EMBRACO e a WEG relataram que fizeram contratos de aquisição de tecnologia com concorrentes para desenvolverem produtos de 
melhor qualidade, assim, desde o início, essas empresas já procuravam monitorar o ambiente tecnológico exterior. Muitas das competências tecnológicas foram encontradas no exterior e internalizadas nas empresas, que deram continuidade ao aperfeiçoamento até desenvolverem uma tecnologia $100 \%$ própria. Dessa forma, pode-se especular que houve uma internacionalização das empresas no início, para apreender um rol de conhecimentos técnicos necessários, e depois disso, deu-se o processo de internalização dessas competências nas matrizes das empresas.

Foram encontradas evidências de que estudar a pesquisa e o desenvolvimento separadamente, propicia um entendimento mais apurado da estratégia da tecnológica da empresa e sua relação com a estrutura organizacional, algo que já havia sido encontrado na literatura pesquisada. Os casos estudados evidenciam que a pesquisa ainda é, majoritariamente, realizada na matriz, enquanto que o desenvolvimento, principalmente por motivos comerciais e produtivos, apresenta um pequeno grau de internacionalização.

Da mesma forma, a internacionalização das empresas estudadas não foi só determinada por seu comprometimento com o mercado exterior, mas, também, foram levadas em conta as estratégias, as vantagens do Paradigma Eclético, a falta de crescimento do mercado interno, e as políticas dos países anfitriões. Esse comprometimento, portanto, dependeria do âmbito estratégico que a empresa atua. No caso da Embraco, o comprometimento com a Itália diminuiu por causa das desvantagens associadas à planta, porém, ao invés de sair do país, a empresa desenvolveu uma estratégia de desinvestimento para tornar a planta sustentável, ao mesmo tempo em que investiu na abertura de uma planta na Eslováquia, mantendo o compromisso com o mercado europeu. Assim, o comprometimento com a internacionalização poderia, a exemplo das unidades no modelo de Ronstadt e Reddy, ser analisado como local, regional e global. Percebe-se assim, que além de utilizar as Teorias de Estratégias e do Paradigma Eclético para avaliar os motivos que levam 
as empresas a investir no exterior, como descrevem Rocha e Almeida (2006), pode-se utilizálos, em conjunto com o Modelo de Uppsala, para a análise do processo de internacionalização da empresa. Da mesma forma que o posicionamento estratégico das plantas no exterior pode evoluir, como sugere o Modelo de Ferdows, a própria internacionalização se ajusta às novas condições de mercado, de tecnologia e de regulamentação, o que faz com que a empresa tenha que ajustar não só a um conjunto inicial de condições, mas também à dinâmica dessas condições no decorrer do tempo. Com isso, o uso dos modelos propicia, além de uma análise pontual da situação da empresa, uma perspectiva histórica da internacionalização e sua contínua dinâmica.

O modelo de Gassmann e Von Zedwitz (1999) de gestão de P\&D internacionalizado demonstra que as empresas estudadas, com exceção da SMAR e da EMBRACO, possuem configurações de pesquisa e desenvolvimento parecidas, centralizando o P\&D e possuindo poucas (ou nenhuma) unidades de desenvolvimento no exterior. A SMAR apresenta suas unidades configuradas independentemente da matriz, algo inusitado, pois pode acarretar em um aumento desnecessário dos custos de coordenação. No caso da EMBRACO, a divisão da empresa em tecnologias dominadas e não-dominadas mostrou-se um interessante método de gestão das inovações tecnológicas. Se por um lado essa gestão mantém a pesquisa e desenvolvimentos das tecnologias não-dominadas centralizados, por outro, cria mecanismos de transferência dessa tecnologia, quando dominada, para as plantas no exterior, disseminando o conhecimento por toda a organização e permitindo que desenvolvimentos posteriores dessa tecnologia sejam realizados no exterior.

O modelo de Chiesa diferencia atividades de P\&D realizadas em laboratórios de pesquisa, das conduzidas em laboratórios de desenvolvimento, analisando os motivos que levariam as empresas a descentralizar esses dois tipos de laboratórios. Para as seis empresas o foco estratégico do P\&D é voltado para a pesquisa, ou seja, suas correntes de inovação são 
baseadas nas habilidades de desenvolvimento tecnológico das próprias empresas. Porém, isso não implica que essas atividades tenham de ser realizadas pela empresa, podendo ser conduzidas por parceiros.

O modelo de Ronsdatd (1977) e Reddy (1997) apresenta uma análise focada nas atividades de P\&D realizadas nas subsidiárias. Quase todas as empresas estudadas apresentaram seu P\&D centralizado, tendo a sua unidade de tecnologia corporativa no Brasil, e as demais sendo unidades de transferência de tecnologia. Contudo, as empresas, em algumas regiões, instalaram unidades de tecnologia regionais e globais, com o intuito de desenvolver produtos específicos para atender os diferentes mercados. A exceção é o caso da Tigre, que apresenta somente unidades de transferência de tecnologia, utilizando-as para monitorar o mercado local.

A internacionalização do P\&D nas empresas estudadas ainda está em seu princípio. Além da SMAR, somente a EMBRACO está planejando internacionalizar sua pesquisa e direcionada para um país em desenvolvimento, a China. De acordo com Von Zedwitz (2005) isso significaria que a EMBRACO estaria transferindo tecnologia de segunda geração, ou oferecendo apoio para outras atividades organizacionais. Porém, de acordo com os entrevistados da empresa, ela pretende internacionalizar-se como forma de aproveitar as taxas de crescimento e o alto número de mão-de-obra especializada. Assim, vemos que além das opções sugeridas pelo autor, as empresas podem internacionalizar-se procurando por vantagens competitivas que sejam utilizadas para o próprio desenvolvimento tecnológico, e não somente para uma replicação tecnológica.

Como comentado por Cassiolato e Lastres (2005), somente as empresas que estiverem envolvidas na criação do conhecimento dispõem de possibilidades reais para absorver e fazer uso pleno do acesso à tecnologia. As empresas estudadas, antes da internacionalização, tiveram que aprender a escanear o ambiente exterior, procurando as melhores práticas ao 
redor do globo e desenvolvendo suas próprias tecnologias e inovações. Isso foi feito não por meio da alocação de unidades próprias no exterior, mas de acordos com Universidades, centros de pesquisas, consultores e concorrentes que forneceram uma "tecnologia de fundo" para que as empresas. Assim, pode-se considerar que a internacionalização do $\mathrm{P} \& \mathrm{D}$ poderia não ser só a instalação de unidades no exterior para a realização de pesquisa e desenvolvimento, mas também, um maneira de aprender a monitorar o ambiente tecnológico mundial, e definir estratégias próprias, para obter acesso a tecnologias e internalizá-las de modo a integrá-las à base de competências da empresa, e, como bem colocaram Archibugi e Pietrobelli (2003), promovendo o aprendizado e o desenvolvimento do capital humano e das capacidades tecnológicas.

De acordo com Santos (2006), as multinacionais tradicionais projetam no mundo o que elas aprenderam nos seus mercados de origem, esta seria a "globalização clássica", que levaria a um mundo homogeneizado. Contudo, o autor sugere que essa globalização está mudando para uma metanacional. Essa nova forma de globalização seria uma fonte alternativa de vantagem para as empresas que queiram inserir-se no mercado global, e que tenham uma visão cosmopolita, além das fronteiras das nações. Assim se estabelece a verdadeira mundialização das empresas, vinculado a um progresso baseado na diversidade (SANTOS, 2006).

...a viabilidade de empresas brasileiras se internacionalizarem é muito maior que a vinte anos. Mas, para que isso se concretize, muitas das organizações brasileiras devem considerar o desafio metanacional e traçar caminhos distintos dos percorridos pelas atuais multinacionais estrangeiras. Assim, a estratégia de internacionalização será diferente da que hoje ainda se prescreve como via dominante (SANTOS, 2006; p. 64-65).

Diante do exposto pode-se concluir que foi fundamental para as empresas estudadas internalizarem as tecnologias captadas no exterior, de forma a desenvolver suas próprias 
habilidades tecnológicas. Cada vez mais as empresas precisam estar atentas aos novos desenvolvimentos tecnológicos, agregando-os aos seus produtos e processos, mas também se responsabilizando por seus direcionamentos, participando ativamente com seu P\&D na rede do conhecimento. A globalização clássica e a projeção das características dos mercados da tríade para o restante do mundo mostrou-se insuficiente para atender as demandas dos mercados "emergentes". Assim, as multinacionais emergentes não deveriam "projetar" seus modelos nos diferentes mercados, mas talvez, como a filosofia da WEG propõe, inserir-se no país anfitrião como uma empresa de lá, entender a cultura local e, paulatinamente, integrar-se à região.

\subsection{LIMITAÇÕES E PROPOSTAS DE PESQUISAS POSTERIORES}

As limitações desta pesquisa estão incorporadas à própria metodologia utilizada, uma vez que os resultados provenientes de estudos qualitativos não permitem a generalização. Contudo, ainda há a possibilidade de utilização do protocolo de pesquisa deste trabalho para coletar dados sobre as demais empresas contidas no quadro 1.1, e confrontar seus resultados com os aqui apresentados, procurando analisar como o desenvolvimento de produtos dessas empresas é feito no exterior e comparar com o desenvolvimento feito no Brasil.

Um segundo estudo poderia ser um mapeamento tecnológico das empresas. Utilizando a citação de patentes, pode-se analisar a dispersão da tecnologia feita pelas empresas e, por outro lado, de onde provém a tecnologia que elas utilizam. Esse estudo pode mostrar as relações tecnológicas entre empresas e aprofundar o estudo sobre a internacionalização de multinacionais brasileiras.

Além disso, as informações qualitativas contidas nesta pesquisa podem servir de referência para outros estudos, para o levantamento de hipóteses e proposições a respeito da 
internacionalização, sobre o P\&D e a internacionalização do desenvolvimento de produtos, tanto para as empresas estudadas quanto outras. 


\section{REFERÊNCIAS}

ABREU, A. F.; FRANCA, T. C. V.; SINZATO, C. I. P. Acesso à informação - promovendo competitividade em P\&D com o uso de tecnologia de informação. Ciência da Informação, Brasília, v. 28, n. 3, p.322-332, 1999.

ALEM, A. C.; CAVALCANTI, C. E. O BNDES e o apoio à internacionalização das empresas brasileiras: algumas reflexões. Revista do BNDES, Rio de Janeiro, v. 12, n. 24, p. 43-76, 2005.

ALTMANN, R. G. As multinacionais brasileiras com plantas industriais no exterior: configuração das operações internacionais. 2005. 162 p. Dissertação (Mestrado) - Escola Politécnica, Universidade de São Paulo, São Paulo, 2005.

ANDERSEN, O. On the internationalization process of the firm: a critical analysis. Journal of International Business Studies, Washington, v. 24, n. 2, p. 209-231, 1993.

ARAÚJO, R. D. Esforços tecnológicos das firmas multinacionais e domésticas. In: DE NEGRI, J. A. SALERNO, M. S. (Org.). Inovações, padrões tecnológicos e desempenho das firmas industriais brasileiras. Brasília: IPEA, 2005, p 119-170.

ARBIX, G. Inovar ou inovar: a indústria brasileira entre o passado e o futuro. 2006. $163 \mathrm{f}$. Tese (Livre-docência). Faculdade de Filosofia, Letras e Ciências Humanas, Universidade de São Paulo, São Paulo, 2006.

ARCHIBUGI, D.; PIETROBELLI, C. The globalisation of technology and its implications for developing countries. Windows of opportunity or further burden? Technical forecasting \& social change, Portland, v. 70, p. 861-883, 2003.

ASSOCIAÇÃO NACIONAL DE PESQUISA, DESENVOLVIMENTO E ENGENHARIA DAS EMPRESAS INOVADORAS [ANPEI]. Como alavancar a inovação tecnológica nas empresas. São Paulo: ANPEI, 2004.

BARTLETT, C. A.; GHOSHAL, S. Creation, adoption and diffusion of innovations by subsidiaries of multinational corporations. Journal of International Business Studies, Washington, v. 19, n. 3, p. 365-388, 1988.

BARTLETT, C. A.; GHOSHAL, S. Gerenciando Empresas no Exterior: a solução transnacional. São Paulo: Makron Books, 1992. 
BLANC, H.; SIERRA, C. The internationalisation of R\&D by multinationals: a trade of between external and internal proximity. Cambridge Journal of Economics, Oxford, v. 23, n. 2, p. 187-206, 1999.

BOSTON CONSULTING GROUP [BCG]. The New Global Challengers: how 100 top companies from rapidly developing economies are changing the world. Boston: BCG Publications, 2006. Disponível em: $<$ http://www.bcg.com/publications/publication_view.jsp?pubID=1849\&language=English $>$. Acesso em: 23 jul, 2006.

CARDOSO, M. A. Estratégia tecnológica e competitividade: o caso da Marcopolo. 2000, 84 f. Dissertação (Mestrado), Universidade Federal do Rio Grande do Sul, Porto Alegre, 2000 .

CARVALHO, R. Q.; BRISOLLA, S.; FURTADO, A.; BERNARDES, R. Força e fragilidade do sistema de inovação paulista. São Paulo em Perspectiva, São Paulo, v.14, n.3, p.124-141, 2000 .

CASSIOLATO, J. E.; LASTRES, H. M. M. Tecnoglobalismo e o papel dos esforços de P,D\&I de multinacionais no mundo e no Brasil. Parcerias Estratégicas, Brasília, n. 20, p. 1179-1200, jun. 2005.

CHIESA, V. Global R\&D project management and organization: a taxonomy. Journal of Product Innovation Management, Nova Iorque, v. 17, n. 5, p. 341-359, 2000.

CHIESA, V. Globalizing R\&D Around Centers of Excellence. Long Range Planning, Londres, v. 28, n. 6, p 19-28, 1995.

COHEN, W. M.; LEVINTHAL, D. A. Innovation and Learning: the two faces of R\&D. The Economic Journal, Londres, n. 99, p 569-596, 1989

CONSONI, F. L; CARVALHO, R. Q. Desenvolvimento de produtos na indústria automobilística brasileira: perspectivas e obstáculos para a capacitação local. Revista de Administração Contemporânea, Curitiba, v. 6, n. 1, p. 39-62, 2002.

CYRINO, A. B; OLIVEIRA JUNIOR, M. M. Global Players Research Investigation on the Internationalization Processes of Companies in Brazil. Caderno de Idéias, Nova Lima, v. CI0224, dez. 2002.

DIAS, A. V.; GALINA, S. V. R. Global Product Development: some case studies in tha brazilian automotive and telecomunication industries. In: INTERNATIONAL 
CONFERENCE ON TECHNOLOGY POLICY AND INNOVATION, 4, 2000, Curitiba. Anais..., Curitiba, 2000.

DIAS, V. V. Las empresas brasileñas: internacionalización y ajuste a la globalización de los mercados. Documento de Trabajo. Brasília: Nações Unidas, v. 33, 1994.

DIOS, V. Smar empresa que inova. Inovação Unicamp. Campinas, 2003. Disponível em: $<$ http://www.inovacao.unicamp.br/index.shtml $>$. Acesso em 19 de setembro de 2006.

DUNNING, J. H. Re-evaluating the Benefits of foreign direct investment. Transnational Corporations, Genebra, v. 3, n. 1, fev. 1994.

EMBRACO. Joinville, 2006. Disponível em: <http://www.embraco.com.br $>$. Acesso em: 28 ago. 2006.

EMERGING giants. BusinessWeek online, New York, v. 3995, 2006. Disponível em: $<$ http://www.businessweek.com/magazine/content/06_31/b3995001.htm $>$. Acesso em: 23 jul. 2006.

ESTORILIO, C. C. A. O trabalho dos engenheiros em situações de projeto de produto: uma análise de processo baseada na ergonomia. 2003. 317 p. Tese (Doutorado) Escola Politécnica, Universidade de São Paulo, São Paulo, 2003.

FERDOWS, K. Making the most of foreign factories. Harvard Business Review, New York, v. 75, n. 2, p. 73-88, 1997.

FLEURY, A.; FLEURY, M. T. L. Para pensar o processo de internacionalização das empresas brasileiras. INOVA - Boletim do núcleo de política e gestão tecnológica da Universidade de São Paulo, São Paulo, v. 13, n. 45, p. 1-3, 2006.

GALINA, S. V. R. Desenvolvimento global de produtos: o papel das subsidiárias brasileiras de fornecedores de equipamentos do setor de telecomunicações. 2006. 311 p. Tese (Doutorado). Escola Politécnica, Universidade de São Paulo. São Paulo, 2003.

GAMMELTOFT, P. Internationalisation of R\&D: trends, drivers and managerial challenges. In: DRUID SUMMER CONFERENCE ON DYNAMICS OF INDUSTRY AND INNOVATION: ORGANIZATIONS, NETWORKS AND SYSTEM, 10, 2005, Copenhagen. Anais.... Copenhagen: DRUID, 2005.

GASSMANN, O.; VON ZEDWITZ, M. Market versus technology drive in R\&D internationalization: four different patterns of managing R\&D. Research Policy, Amsterdam, v. 31, n. 4, p. 569-588, 2002. 
GASSMANN, O.; VON ZEDWITZ, M. New concepts and trends in international R\&D organization. Research Policy, Amsterdam, v. 28, n. 2/3, p. 231-250, 1999.

GASSMANN, O.; VON ZEDWITZ, M. Trends and determinants of managing virtual R\&D teams. R\&D Management, Oxford, v. 33, n. 3, p. 243-262, 2003.

GERDAU. Porto Alegre, 2001. Disponível em: <http://www.gerdau.com.br>. Acesso em: 28 ago. 2006.

GERYBADZE, A.; REGER, G. Globalisation of R\&D: recent changes in the management of innovation in transnational corporations. Research Policy, Amsterdam, v. 28, n. 2/3, p. 251274, 1999.

GRABER, D. R. How to manage a global product development process. Industrial Marketing Management, Nova Iorque, v. 25, n. 6, p. 483-489, 1996.

GRANSTRAND, O.; PATEL, P.; PAVITT, K. Multi-technology corporations: why they have "distributed" rather than "distinctive core" competencies. California Management Review, Berkeley, v. 39, n.4, 1997.

GROEN A. J.; WEERD-NEDERHOF P. C.; KERSSENS-VAN DROGELEN, I. C.; BADOUX, R. A. J.; OLTHIUS, G. P. H. Creating and justifying research and development value: scope, scale, skill and social networking of $R \& D$. Creativity and Innovation Management, Oxford, v. 11, n. 1, p. 2-16, 2002.

HEMAIS, C. A.; HILAL, A. O Processo de Internacionalização na a Ótica da Escola Nórdica: evidências empíricas em empresas brasileiras. Revista de Administração Contemporânea, Curitiba, v. 7, n. 1, p. 109-124, 2003.

IGLESIAS, R.; MOTTA VEIGA, P. Promoção de exportações via internacionalização das firmas de capital brasileiro. In PINHEIRO, A.; MARKWALD, R.; PEREIRA, L. (orgs.), $\mathbf{O}$ desafio das exportações. Rio de Janeiro: BNDES, 2002. p. 367 - 446.

JANKOWSKY, J. E. R\&D: foundation for innovation. Research Technology Management, Arlington, v. 41, n. 2, p. 14-20, 1998.

JOHANSON, J.; VAHLE, J. The internationalization process of the firm - a model of knowledge development and increasing foreign market commitment. Journal of International Business Studies, Washington, v. 8, n. 1, p. 23-32, 1977. 
KERSSENS-VAN DROGELEN, I. C.; NIXON, B.; PEARSON, A. Performance measurement in industrial R\&D. International Journal of Management Reviews, Oxford, v. 2, n. 2, p. 111-143, 2000a.

KERSSENS-VAN DROGELEN, I. C.; NIXON, B.; PEARSON, A. R\&D as a business what are the implications for performance measurement. R\&D Management, Oxford, v. 30, n. 4, p. 355-366, 2000b.

KLINE, S. J.; ROSEMBERG, N. An overview of innovation. In: LANDAU, R.; ROSENBERG, N. (eds.), The positive sum strategy: harnessing technology for economic growth, Washington, DC: National Academy Press, p. 275-306, 1986.

LAMBIN, J. J. Market-driven Management: strategic and operational marketing. Great Britain: Palgrave Press, 2000.

LIAO, Z.; GREENFIELD, P. F. Corporate R\&D strategy portfólio in Japanese and Australian technology-based firms: a empirical study. IEEE Transactions on engineering management, Nova Iorque, v. 45, n. 4, p. 323-330, 1998.

LIYANAGE, S.; GREENFIELD, P. F.; DON, R. Towards a fourth generation R\&D management model-research networks in knowledge management. International Journal of technology management, Genebra, v. 18. n. 3/4, p. 372-394, 1999.

MALHOTRA, N. K. Pesquisa de marketing: uma orientação aplicada. 3.ed. Porto Alegre: Bookman, 2001.

MARCOPOLO. Caxias do Sul, 2006. Disponível em: http://www.marcopolo.com.br. Acesso em: 17 de março de 2007.

MARTINS, G. de A. Estudo de caso: uma estratégia de pesquisa. São Paulo: Atlas, $2006 a$.

MARTINS, J. A. Internacionalização da Marcopolo. Rio de Janeiro, 2005. (Apresentação da palestra realizada no V Workshop em Internacionalização de empresas (COPPEAD)).

MARTINS, J. A. Internacionalização da Marcopolo. São Paulo, 2006b (Apresentação da palestra realizada na FGV/EAESP - São Paulo no dia 07/12/2006).

MAUAD, T. M.; MARTINELli, D. P.; LIBONI, L. B.; A dinâmica da inovação no desenvolvimento do ciclo de vida das organizações: um estudo de caso. In: SEMEAD, 9, 2006, São Paulo. Anais... São Paulo, 2006. 
MEDCOF, J.W. A taxonomy of internationally dispersed technology units and its application to management issues. R\&D Management, Oxford, v. 27, n. 4, 301-318, 1997.

MELIN, L. Internationalization as a strategy process. Strategic Management Journal, Chichester, v. 13, Edição especial de Inverno, p. 99-118, 1992.

MEYER, C. B. A case in case study methodology. Field methods, Gainesville, v. 13, n. 4, p. 329-352, 2001.

MORGAN, R. E.; KATSIKEAS, C. S. Theories of international trade, foreign direct investment and firm internationalization: a critique. Management Decision, Londres, v.35, $\mathrm{n}$. 1, p.68-78, 1997.

NARULA, R.; DUYSTERS, G. Globalisation and trends in international R\&D alliances. Journal of International Management, Filadélfia, v.10, n. 2, p. 199- 218, 2004.

NETZ, C. Empresas brasileiras crescem no mercado global. O Estado de São Paulo, São Paulo, 5, out., 2006. Brasil com Z.

NEVES, J. L. Pesquisa qualitativa - características, usos e possibilidades. Caderno de pesquisa em administração, São Paulo, v. 1, n. 3, p. 1-5, 1996.

OGBUEHI, A. O.; BELLAS JUNIOR, R. A. Decentralized R\&D for global product development: Strategic implications for the multinational corporation. International Marketing Review, Londres, v. 9, n. 5, p. 60-70, 1992.

ORGANIZATION FOR ECONOMIC CO-OPERATION AND DEVELOPMENT [OECD], Science, Technology and Industry Outlook 2004. Paris, 2004.

ORGANIZATION FOR ECONOMIC CO-OPERATION AND DEVELOPMENT [OECD]. Frascati Manual. Paris, 2002.

PATEL, P.; LE BAS, C. Does internationalization of technology determine technological diversification in large firms?. SEWPS, Brighton, n. 128, 2005.

PORTER, M. The competitive advantage of nations. New York: The Free Press, 1990.

REDDY, P. New Trends in Globalization of Corporate R\&D and Implications for Innovation Capability in Host Countries: a Survey from India. World Development, Oxford, v. 25, n. 11, p. 1821-1837, 1997. 
ROCHA, A.; ALMEIDA, V. Estratégias de entrada e de operação em mercados internacionais. In. TANURE, B.; DUARTE, R. G. (Orgs.). Gestão Internacional. São Paulo: Saraiva, 2006. p. 7 - 37.

ROGERS, D. M A. The challenge of fifth generation R\&D. Research Technology Management, Washington, vol. 39, n. 4, p. 33-41, 1996.

RONSTADT, R. C. International R\&D: the establishment and evolution of research and development abroad by seven U.S. multinationals. Journal of International Business Studies, Washington, v. 9, n.1, p. 7-24, 1978.

ROSELINO, J. E.; GOMES, R. Limites e possibilidades do Brasil nas configurações produtivas globalizadas: software e as cadeias produtivas internacionalizadas. Araraquara e Campinas, 2000. (Relatório Final de Pesquisa).

SANTOS, J. F. P. O desafio multinacional. In. TANURE, B.; DUARTE, R. G. (Orgs.). Gestão Internacional. São Paulo: Saraiva, 2006. p. 63 - 79.

SBRAGIA, R.; STAL, E. Tecnologia e Inovação: experiência de gestão na micro e pequena empresa. São Paulo: PGT/USP, 2002.

SMAR. Sertãozinho, 2001. Disponível em: <<http://www.smar.com.br $>>$ Acesso em: 17 de março de 2007.

TAKAHASHI, S.; TAKAHASHI, V. P. Gestão de inovação de produtos: estratégia, processo, organização e conhecimento. Rio de Janeiro: Elsevier. 2007.

TEECE, D. J.; PISANO, G.; SHUEN, A. Dynamic capabilities and strategic management. Strategic Management Journal, Chichester, v. 18, n. 7, p. 509-533, 1997.

TEIXEIRA, G. O que significa metodologia?. Módulo: metodologia da pesquisa. São Paulo, 2005. Disponível em: <http://www.serprofessoruniversitario.pro.br $>$. Acesso em: $11 \mathrm{abr}$. 2006.

TIGRE. Joinville, 2005. Disponível em: <http://www.tigre.com.br $>$. Acesso em: 29 ago. 2006.

URBAN, T. P. O processo de internacionalização de uma multinacional brasileira. 2006. 99 p. Tese (Mestrado) Faculdade de Economia, Administração e Contabilidade, Universidade de São Paulo, São Paulo, 2006. 
VIEIRA, C. R. B.; ZILBOVICIUS, M. Empresas brasileiras com plantas industriais no exterior. In: WORKSHOP DE INTERNACIONALIZAÇÃO DE EMPRESAS, 5, 2005, Rio de Janeiro. Anais... Rio de Janeiro: COPPEAD, 2005.

VON ZEDWITZ, M. International R\&D in companies from developing countries. In: UNCTAD. Globalization of R\&D in developing countries. Genebra: UN, 2005. p 117 140.

WEG. Jaraguá do Sul, 2006. Disponível em: <http://www.weg.com.br>. Acesso em: 27 ago. 2006.

WELCH, L.S.; LUOSTARINEN, R. Internationalisation: evolution of a concept. Journal of General Management, Henley-on-Thames, v. 14, n. 2, p. 34-55, 1988.

YIN, R. K. Estudo de Caso: planejamento e métodos. 3. ed. Porto Alegre: Bookman, 2005. 


\section{APÊNDICE}

\section{A - AS EMPRESAS SELECIONADAS}

Como já foi mencionado, as empresas que foram estudadas neste trabalho são multinacionais brasileiras com unidades produtivas fora do Brasil. Seus históricos são diferentes e neste capítulo foi feita uma breve introdução para cada uma delas.

\section{EMBRACO}

A Embraco foi fundada em 1971 em Joinville (SC), onde, atualmente, mantém: uma unidade fabril, a administração, o centro de pesquisa e desenvolvimento, a Fundição Embraco e a EECON - Embraco Electronics Controls - que desenvolve, fabrica e comercializa sistemas eletrônicos para eletrodomésticos. Em Itaiópolis (SC), a empresa possui outra fábrica, dedicada à produção de componentes elétricos e trocadores de calor, utilizados em unidade de condensadores e seladas. Os produtos da empresa são: compressores, componentes de ferro fundido, componentes elétricos, condensadores e evaporados. Sua participação de mercado é de $20 \%$ em relação a vendas e emprega cerca de dez mil pessoas (EMBRACO, 2006).

\section{Internacionalização}

A empresa conta hoje, com fábricas no Brasil, Itália, China e Eslováquia. Este processo de abertura das bases produtivas para o exterior teve início nos primeiros anos de 1990. A planta italiana da Embraco, adquirida em 1994 está localizada em Riva presso Chieri.

Com a marca Áspera, essa fábrica já produzia compressores desde 1956. Em Spisská Nová Vês, na Eslováquia, a Embraco inaugurou uma planta em 1999, direcionada para a 
refrigeração comercial, e a produção de compressores e de unidades condensadoras. Em 1995, ela estabeleceu uma joint-venture na China, na zona central de Beijing, dando origem à Embraco Snowflake. Em maio de 2006, a produção na China foi transferida para uma nova fábrica na mesma cidade, e passou a abrigar um centro de P\&D (EMBRACO, 2006).

\section{Tecnologia}

A Embraco começou a desenvolver tecnologia própria em 1981, por meio de parcerias com universidades e centros de pesquisa. Dois anos depois, implantou uma área de P\&D com a função estratégica de consolidar os conhecimentos adquiridos sobre os produtos. Atualmente possui uma área física e um quadro funcional voltado à Pesquisa e Desenvolvimento, para os quais são alocados recursos da ordem de 3\% das vendas líquidas anuais (ABREU; FRANCA; SINZATO, 1999).

A partir da criação de seu próprio núcleo de pesquisa e o desenvolvimento de parcerias com universidades e centros de pesquisa, no país e exterior, a Embraco passou em 1987 a ser líder nos Estados Unidos do mercado de compressores de alta eficiência (ABREU; FRANCA; SINZATO, 1999, p. 324).

No âmbito mundial, o Centro de Pesquisa e Desenvolvimento da Embraco já obteve cerca de 550 patentes em âmbito mundial e nele trabalha uma equipe de cerca de 400 engenheiros e técnicos. Esse centro de P\&D conta ainda com o suporte de 37 laboratórios próprios, localizados nas diferentes plantas (EMBRACO, 2006).

\section{GERDAU}

A empresa iniciou suas operações em 1902, com a Fábrica de Pregos Ponta de Paris, na cidade de Porto Alegre, Rio Grande do Sul. Em 1948, a empresa entra para o setor 
siderúrgico, com a instalação da Usina Riograndense e, em 1968, inicia a produção em Pernambuco, com a Açonorte. Hoje, a empresa tem como principal produto os vergalhões para a construção civil. Em 2004, seu faturamento total chegou a R\$ 23,4 bilhões, um aumento de $48 \%$ em relação ao ano anterior. Ainda em 2004, a empresa possuía 20160 funcionários, alocados geograficamente da seguinte forma: $71 \%$ no Brasil, $25 \%$ EUA e Canadá e 4\% entre Argentina, Chile e Uruguai (ALTMANN, 2005). O grupo Gerdau possui usinas siderúrgicas distribuídas no Brasil, Argentina, Canadá, Chile, Colômbia, Estados Unidos e Uruguai. Hoje, alcança uma capacidade instalada total de 19 milhões de toneladas de aço por ano (GERDAU, 2001).

\section{Internacionalização}

A empresa iniciou seu processo de internacionalização em 1980, com a aquisição da siderúrgica Laisa, no Uruguai. Em 1989 comprou a usina Courtice Steel no Canadá, e em 1995, a MRM Steel no mesmo país. Ainda na década de 90, outros investimentos foram realizados desta vez na América do Sul, com a compra das empresas Indac e Aza, do Chile em 1992, e em 1998, com a aquisição de 38,2\% da Sinpar Rosário, de Rosário, na Argentina. Em 1999, a Gerdau adquiriu a Ameristeel, empresa já conceituada no mercado americano e possuidora de sete usinas, e em 2002, a também norte-americana Birminghem Southwest e unificou as operações, criando a Gerdau Ameristeel Corporation. A América do Sul também foi alvo de mais investimentos em 2004, com a compra de $53 \%$ da Diaco S.A. e $60 \%$ da Siderúrgica del Pacífico S.A., ambas localizadas na Colômbia. Recentemente, a empresa adquiriu $40 \%$ da participação societária na empresa Sinedor, localizada na Espanha (GERDAU, 2001). 


\section{Tecnologia}

Do ponto de vista de tecnologia, a aquisição da Sidenor é a mais relevante. As outras unidades da empresa trabalham com um produto tradicional, o que faz com que as inovações nessas unidades sejam voltadas para os processos. Na usina da Espanha, o produto são os aços especiais, um produto com um maior valor agregado e que necessita de um P\&D especializado. Outro ponto é que essa usina já possui um departamento de $\mathrm{P} \& \mathrm{D}$ formado. $\mathrm{O}$ quadro a seguir (4.1), mostra a distribuição geográfica das usinas de aço da empresa, bem como sua capacidade produtiva de aço no Brasil e no exterior.

\begin{tabular}{l}
\hline \multicolumn{1}{|c|}{ Distribuição geográfica da Gerdau } \\
\hline Brasil \\
\hline Capacidade produtiva: 9 milhões de toneladas de aço bruto. \\
\hline Capacidade produtiva: 5,5 milhões de toneladas de produtos laminados. \\
\hline 11 usinas siderúrgicas \\
\hline 11 centros de serviços de corte e dobra \\
\hline 6 unidades de transformação e seções especiais \\
\hline Exterior \\
\hline Capacidade produtiva: 9,7 milhões de toneladas de aço bruto. \\
\hline Capacidade produtiva: 9,3 milhões de toneladas de produtos laminados. \\
\hline 19 usinas siderúrgicas. \\
\hline 38 centros de serviços de corte e dobra. \\
\hline 15 unidades de transformação e seções especiais. \\
Quadro A1 - Distribuição geográfica da Gerdau \\
Fonte: GERDAU (2001)
\end{tabular}

\section{SMAR}

A Smar Equipamentos Industriais Ltda. é uma das líderes mundiais em tecnologia de automação industrial, com filiais em sete países. Na década de 80, a empresa iniciou operações voltadas para os setores de mineração, químico, de bebidas, alimentos, petróleo e outros. Atualmente, está transferindo a sua tecnologia de medição usada em grandes empreendimentos industriais, para prédios de apartamentos e escritórios, shoppings, hospitais 
e condomínios residenciais (GAZETA MERCANTIL, 1999). A empresa compete diretamente com as grandes empresas de automação industrial e tecnologia de ponta do mundo, ficando em segundo lugar, no ranking mundial de empresas do ramo (MAUAD; MARTINELLI; LIBONI, 2006) e mantém dois laboratórios de pesquisa, em Houston e Nova York, nos Estados Unidos.

A empresa foi fundada em 1974, com objetivo de prestar serviços de campo para turbinas a vapor da indústria açucareira brasileira. As indústrias financiadas pelo Pró-álcool repassavam parte dos recursos para a Smar que, por sua vez, desenvolvia produtos com novas tecnologias que atendessem o setor (DIOS, 2003).

Porém, em1982, com o fim do Pró-álcool, a empresa viu-se impelida a buscar mercados alternativos e voltou-se para o desenvolvimento de instrumentos para controle de processos (ROSELINO; GOMES, 2000). Assim, produtos antes restritos ao setor do açúcar e do álcool, começaram a ser desenvolvidos para atender outras indústria, por exemplo, a petroquímica (DIOS, 2003).

Em 1997 a demanda da indústria química e petroquímica representou a parte mais significativa dos seus negócios, cerca de 35\%, seguida pelas áreas de siderurgia e do açúcar e do álcool, cada uma com $17 \%$ do faturamento. O restante ficou distribuído entre outros segmentos da manufatura, como mineração, indústria alimentícia e papel e celulose (ROSELINO; GOMES, 2000).

Mesmo concorrendo com grandes multinacionais, a empresa tornou-se uma das líderes no projeto e na fabricação de transmissores inteligentes de pressão e temperatura, especialmente com tecnologia fieldbus ${ }^{1}$ (ROSELINO; GOMES, 2000). Foi devido a essa

\footnotetext{
${ }^{1}$ Em linhas básicas, o fieldbus permite que um simples par de fios alimente e leve os sinais de comunicação entre os dispositivos de campo e a sala de controle. Esta característica significa uma economia gigantesca em cabos, bandejas, racks e custos de mão de obra para instalação, substituição de bandeja e de conduítes danificados pela corrosão em plantas com atmosferas agressivas.
} 
tecnologia que a Smar obteve, nos últimos cinco anos, uma média de crescimento de 27,5\% (DIOS, 2003).

O setor de automação industrial da empresa - que produz quase 70 tipos diferentes de equipamentos - agrega serviços e desenvolve software, e responde por $95 \%$ do faturamento da empresa. Os 5\% restantes são provenientes da área de periféricos. Seu produto principal, o transmissor de pressão digital, corresponde a 40\% das receitas. Em 2000, mais de um terço da produção da empresa era vendido no mercado internacional (ROSELINO; GOMES, 2000). Em 2003, a empresa contava com 1200 funcionários, 285 deles com nível superior sendo 40 mestres e 3 doutores (DIOS, 2003).

\section{Tecnologia}

A Smar reinveste atualmente cerca de $10 \%$ de seu faturamento bruto em pesquisa e desenvolvimento, uma parte em Nova York, EUA, onde são manufaturados chips e placas, e outra parte em Sertãozinho, responsável pela montagem final dos equipamentos (ROSELINO; GOMES, 2000). Em 2002, dos US\$ 60 milhões de faturamento da empresa, 16\% foram direcionados para a área de pesquisa e desenvolvimento (DIOS, 2003).

Em 2003, trabalhavam em Sertãozinho 110 funcionários, 100 deles engenheiros formados pelas grandes instituições de ensino do país, como o ITA, a USP, Unicamp e UFRJ. Divididos em 10 grupos de trabalho, esses profissionais atuavam nos setores de laboratório, comunicação, equipamentos de campo, blocos funcionais, industrialização, interface, sistemas, layout, certificação e testes e qualidade (DIOS, 2003).

As pesquisas na Smar, em geral, nascem de um programa maior elaborado pela diretoria da empresa e sua equipe de P\&D, o PGD - Planos Gerais de Desenvolvimento. O PGD 2 tinha por meta principal conquistar o mercado externo, o terceiro objetivava o 
desenvolvimento da plataforma Fieldbus. Em 2003, a equipe já estava trabalhando no PGD 4 cujo principal objetivo era desenvolver a plataforma Fieldbus para Internet (DIOS, 2003).

Além do departamento de P\&D chefiado por Libânio, a Smar possui outras unidades de pesquisa, o departamento de pesquisa mecânica e dois laboratórios de desenvolvimento, um em Nova Iorque e outro em Houston. "Para esses dois laboratórios mandamos nossos grupos que fazem levantamento de pesquisa inicial", conta Libânio. (DIOS, 2003).

\section{Internacionalização}

O processo de internacionalização iniciou-se pelos Estados Unidos em 1989, e chegou à Europa em 1990. Em 2000, a empresa já contava com subsidiárias nos Estados Unidos, México, Alemanha, França, Singapura e em Pequim, além de um Centro de Serviços na Noruega. A rede comercial possuía mais de 90 representantes em mais de 50 países de todo o mundo (ROSELINO; GOMES, 2000).

Em 2003, a Smar possuía 11 unidades em Sertãozinho, laboratórios em Nova Iorque e também em Houston (nos Estados Unidos); e filiais na Alemanha, Argentina, China, Cingapura, Estados Unidos, França e México. Em 2003, aproximadamente $40 \%$ do faturamento da empresa provinha das vendas ao exterior (DIOS, 2003).

\section{TIGRE}

A Tigre iniciou suas operações, na cidade de Joinville, em 1941, como uma fábrica de pentes e cachimbos feitos a partir chifres de boi. Alguns anos depois, com a disseminação do plástico, a empresa começou a utilizar essa nova matéria-prima na fabricação de produtos como pentes, piteiras, copos, pratos, brinquedos e leques. No fim dos anos 50, resolveu 
investir em um novo projeto, usando o PVC para fabricar tubos e conexões para instalações hidráulicas (TIGRE, 2005).

\section{Internacionalização}

Em 1977, a Tigre constituiu a empresa Tubopar, em Lamboré, no Paraguai, uma jointventure com empresários locais. Hoje, sua participação no mercado paraguaio de tubos e conexões de PVC é de 80\%. Em 1997, a companhia adquiriu o controle da empresa Fanaplas, no Chile, e em 1998 deu início a suas operações fabris na Argentina, com a inauguração de uma unidade em Pilar, Buenos Aires e em 1999, assumindo a Santorelli, também na capital Argentina. Ainda em 1999, adquiriu mais três empresas chilenas. Em 2000, comprou a Plasmar, na Bolívia (TIGRE, 2005). No quadro seguinte (4.2) têm-se as localizações dos centros operacionais da Tigre no exterior.

\begin{tabular}{|l|l|}
\hline \multicolumn{1}{|c|}{ País } & \multicolumn{1}{c|}{ Centros operacionais no exterior } \\
\hline Bolívia & $\begin{array}{l}2 \text { centros localizados em La Paz e Santa } \\
\text { Cruz de la Sierra. }\end{array}$ \\
\hline Paraguai & 1 centro localizado em Lambaré. \\
\hline Argentina & 1 centro localizado em Buenos Aires. \\
\hline Chile & 2 centros ambos localizados em Santiago \\
\hline
\end{tabular}

Quadro A2 - Centros operacionais da Tigre no exterior

Fonte: TIGRE, (2005).

\section{WEG}

Fundada em 1961, em Jaraguá do Sul, SC. A WEG produziu inicialmente motores elétricos, começou a expandir suas atividades a partir da década de 80, com a fabricação de geradores, componentes eletroeletrônicos, produtos para automação industrial, transformadores de força e distribuição, tintas líquidas e em pó, e vernizes eletroisolantes (WEG, 2006). 


\section{Internacionalização}

Hoje a WEG é uma das maiores fabricantes de motores elétricos da América Latina, está presente em mais de 100 países, possuindo três unidades fabris na Argentina, duas no México, uma em Portugal e uma na China. (WEG, 2006).

\section{Tecnologia}

Durante os anos 60 e 70, a WEG montou laboratórios - físico-químico, metalográfico, elétrico, mecânico e de metrologia - os quais, na década de 80, formaram o Centro Tecnológico. Com equipes próprias de pesquisadores, a empresa mantém laboratórios, onde realiza ensaios e fabricação de protótipos. Paralelamente, incrementa relações de intercâmbio tecnológico com centros de pesquisa de universidades brasileiras e internacionais. Os investimentos em pesquisa e desenvolvimento tecnológico, desde a fundação, absorvem anualmente cerca de 3,5\% do seu faturamento global (WEG, 2006).

\section{MARCOPOLO}

A Marcopolo tem sua matriz instalada na cidade de Caxias do Sul, RS. Fundada em 1949 como Nicola e Cia Ltda, a Marcopolo atualmente é, em participação de marcado, a maior encarroçadeira de ônibus no Brasil. A empresa possui 10590 colaboradores, sendo 8151 no Brasil e 2439 no exterior (MARTINS, 2006b). Sua capacidade de produção no Brasil é de 70 unidades por dia, enquanto que a do grupo todo é de 110 unidades por dia. A produção do ano passado, até outubro, foi de 23463 unidades. A participação mundial de mercado da Marcopolo era de 6,5\% em 2005, patamar que permaneceu inalterado em 2006 (MARTINS, 2005; MARTINS, 2006b). 


\section{Internacionalização}

A Marcopolo possui atualmente quatro fábricas operando fora do Brasil: a Marcopolo Portugal, a Marcopolo South África, a Superpolo em Bogotá, Colômbia, e a Polomex em Monterrey, no México.

Em 1991 a Marcopolo iniciou seu processo de internacionalização com a instalação de sua primeira fábrica fora do Brasil, localizada na cidade de Coimbra, em Portugal. Em função da participação do país no bloco econômico da comunidade européia, em seus primeiros anos de atuação, a Marcopolo Portugal concentrou-se na prospecção de mercados, pesquisando as necessidades do consumidor europeu, para, posteriormente, desenvolver um produto que atingisse os índices de satisfação do usuário final nos conceitos de design, funcionalidade, conforto e segurança. Atualmente sua capacidade de produçãoé de 250 unidades por ano.

No ano de 2000, a Marcopolo firmou uma parceria com a Scania South Africa Pty Ltd., localizada na cidade de Pietersburg, na África do Sul, para o fornecimento de tecnologia e gestão industrial na produção do ônibus urbano Torino. No final de 2001, instalou fábrica própria na cidade de Johanesburgo e sua capacidade de produção é de 700 unidades por ano.

Em 2000, no contexto do projeto Transmilênio ${ }^{2}$, e do processo de internacionalização da empresa, a Marcopolo firmou joint venture com a maior fabricante de carrocerias da Colômbia, a Carrocerias Superior, também conhecida como Superbus, e constituiu a Superpolo, instalada na zona industrial ao sul de Bogotá, nas antigas instalações da Superbus. A tecnologia e a responsabilidade técnica da Superbus foram, adaptadas ao sistema Marcopolo de produção e atualmente a Superpolo, com 50\% de participação da Marcopolo e

\footnotetext{
${ }^{2} \mathrm{O}$ projeto Transmilênio consiste num sistema de transporte coletivo desenvolvido com objetivo de solucionar o caos do transporte na cidade de Bogotá, Colômbia.
} 
$50 \%$ Superbus. Fabrica produtos específicos para a região do Pacto Andino e tem uma capacidade de produção de 2.800 unidades por ano.

A Polomex foi fundada em 1999, na cidade de Aguascalientes, no México. A partir de 2001, a Evobus, divisão da DaimlerChrysler, adquiriu 26\% de participação de seu capital societário. A linha de produção foi então transferida para a cidade de Monterrey, na unidade fabril da Mercedes-Benz México. A parceria viabilizou a produção e entrega aos clientes de produtos pelo sistema "pára-choque a pára-choque"; ou seja, com garantia unificada e integral, uma vez que carroceria e chassi são objetos de uma venda conjunta. O desempenho de mercado demonstra que as linhas paralelas de fabricação da carroceria e do chassi constituem uma fórmula de sucesso na região de atuação da Polomex. Sua capacidade de produção é de 2.000 unidades por ano.

Além dessas unidades, a Marcopolo possui uma unidade de transferência de tecnologia localizada na China, e uma planta produtiva que está atualmente desativada na Argentina.

\section{Tecnologia}

A Marcopolo não compra tecnologia, seus produtos são desenvolvidos internamente, exceto, máquinas e processos já de domínio público. A informação chega na empresa por meio das feiras, fornecedores e análises de benchmarking, principalmente no exterior. Algumas das inovações acabam sendo adaptadas ao contexto da realidade brasileira e dos mercados nos quais a Marcopolo atua (CARDOSO, 2000). A Marcopolo, não dispõe de uma área de $\mathrm{P} \& \mathrm{D}$ formalmente definida e, portanto, não tem uma diretoria específica de pesquisa e

desenvolvimento (CARDOSO, 2000). É a área de engenharia que canaliza para análise e desenvolvimento todas as necessidades de mercado que possam vir a interessar à empresa. A engenharia é também a fonte de sugestões de novos processos e produtos que aparecem em 
feiras, revistas técnicas e fornecedores. Este setor, por sua vez, tem a seguinte configuração: departamento de engenharia de produto, departamento de engenharia de processo e departamento de engenharia de desenvolvimento (CARDOSO, 2000).

Estes departamentos envolvem aproximadamente 200 funcionários entre desenhistas, projetistas, técnico-projetistas, e engenheiros-projetistas. Nos departamentos de produto e de desenvolvimento, onde se concentram as atividades tecnológicas, a grande maioria dos funcionários tem formação universitária (CARDOSO, 2000). Além disso, há cerca de dois anos, foi criada a área de desenvolvimento de Novos Produtos e Mercados, que contempla o conceito de marketing. Há uma equipe que sai a procura de oportunidades, tanto no mercado interno quanto no externo, e traz a idéia do que poderia ser desenvolvido para atender a determinado mercado. Depois disso, acontece o desenvolvimento final do produto, quando a idéia é configurada frente a realidade da empresa e exeqüibilidade do projeto (CARDOSO, 2000). 